\title{
Cooling and Vesiculation of Alae Lava Lake, Hawaii
}

GEOLOGICAL SURVEY PROFESSIONAL PAPER 935-B

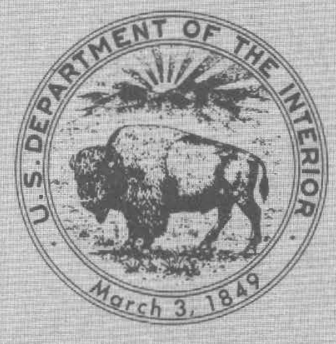





\section{Cooling and Vesiculation of Alae Lava Lake, Hawaii}

By D. L. PeCK

SOL I IFICA T I N OF A L A E L A A LAKE, HA W A I GEOLOGICAL SURVEY PROFESSIONAL PAPER $935-\mathrm{B}$

Repeated measurements of temperatures in drill holes and the altitude of the surface document the cooling of a thin ponded basalt flow

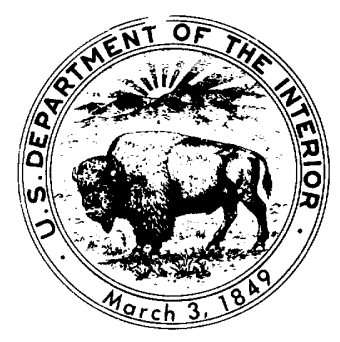




\section{UNITED STATES DEPARTMENT OF THE INTERIOR}

CECIL D. ANDRUS, Secretary

\section{GEOLOGICAL SURVEY}

W.A. Radlinski, Acting Director

Library of Congress Cataloging in Publication Data

Peck, Dallas Lynn, 1929-

Cooling and vesiculation of Alae Lava Lake, Hawaii.

(Solidification of Alae Lava Lake, Hawaii)

(Geological Survey Professional Paper 935-B)

Bibliography: p. 49-50.

Supt. of Docs. No.: 119.16:935-B

1. Basalt--Hawaii--Alae Lava Lake. I. Title. II. Series. III. Series: United States Geological Survey Professional Paper 935-B.

QE462.B3P4

$552^{\prime} .2$

$77-608302$

For sale by the Superintendent of Documents, U.S. Government Printing Office Washington, D.C. 20402

Stock Number 024-001-03053-5 


\section{CONTENTS}

Abstract Page

Introduction

Acknowledgments ............ 3

Methods of study _... 3

Drilling _-........- 3

Temperature measurements _.................. 5

Measurements of the altitude of the lake surface -..- 6

Precipitation and air temperatures _............. 7

Temperatures in the lava lake

Definition of crust and fluid lava

Effect of coolant water on temperatures................. 11

Temperatures in fluid lava below the crust _..._._._. 12

Thermal history of the lake _.......... 13

Maximum temperatures and temperatures at the basal contact

Density of Alae lava and variation with time of the altitude of the lake surface
Density of Alae lava and variation with time-Continued Density and vesicularity

Altitude of the lake surface _-_._- 23

Changes in altitude during solidification _........... 24

Changes in horizontal distance during solidification $\ldots$

Changes in altitude during further cooling _........ 31

Interpretation of changes in altitude ............... 32

Subsidence of the lake surface and calculation of the coefficient of thermal expansion _-_._-_._-_._. 32

Changes in altitude of the surface during solidification of the lake _... 33

Calculation of the density of fluid lava in the lake

The pattern of cooling in three dimensions -

Thermal properties of Alae basalt _._._. 40

Thermal modeling

Conclusions

References cited

\section{ILLUSTRATIONS}

Figure 1. Map of Alae lava lake showing contours at the base and margin and the location and identification number of surveying stations and drill holes

2. Photograph showing drilling in Alae lava lake

3-17. Graphs showing:

3. Representative temperature profiles

4. Temperature and depth of the tip of a hollow mullite probe as a function of time during its insertion into fluid lava

5. Thickness of the upper crust near the main drilling site as a function of time

6. Temperature profile across the zone of crystallization at the base of the crust on December 30,1963

7. Temperatures near the bottom of drill hole 3 after drilling through the base of the crust

8. Depth of isotherms in drill hole 4 before and after drilling on November 27, 1963

9. Temperature profile across partly molten crust and into underlying fluid lava on November $8,1963 \ldots$

10. Depth of isotherms and rainfall from August 1963 to August 1967

11. Depth of isotherms from August 22 to September 17, 1963

12. Temperature profiles in the upper part of drill hole 5 showing the effects of abundant rainfall

13. Temperature profiles in five drill holes on January 21,1965 , and a computed profile

14. Maximum temperatures at three sites as a function of time

15. Proportionate depth of the maximum temperature

16. Average core density and porosity (vesicularity) as a function of depth

17. Maximum size of vesicles as a function of depth

18. Photomicrograph of vesicular basalt

19. Graph showing vesicularity as a function of time

20. Graph showing estimated rate of vesiculation and cumulative abundance of vesicles as a function of temperature

21. Map showing rate of change in altitude of the lake surface during solidification of the lake from August 30 to September 24 to 26,1963

22. Map showing rate of change in altitude of the lake surface during solidification of the lake from September 24 to 26 , 1963, to September 24, 1964

23. Graph showing cumulative changes in altitude of five stations .

(1)

(4)

5

6

9

0

1

23


Figures 24-27. Maps showing:

24. Total uplift of the lake surface

25. Changes in horizontal distance between stations during solidification of the lake

26. Rate of subsidence of the lake surface after complete solidification in late September 1964

27. Estimated daily average decrease in temperature in the lake from January to August 1965, as determined from measured rates of subsidence

28-30. Graphs showing:

28. Rates of uplift and subsidence of stations on the lake compared with maximum temperatures in the lake

29. Observed and calculated rates of uplift and subsidence at the main drilling site

30. Temperature profiles on September 25, 1963, and August 19, 1965, and a section through the lake on September 25, 1963

31. Map showing approximate position of the outer margins of the $1,080^{\circ} \mathrm{C}$ isothermal surface in the lake as a function of time

32. Map showing outer margins of the $1,000^{\circ} \mathrm{C}$ isothermal surface (approximately the solidus) as a function of time

33. Longitudinal cross section showing the positions of the $1,000^{\circ} \mathrm{C}$ isothermal surface as a function of time

34. Longitudinal cross section showing the positions of the $700^{\circ} \mathrm{C}$ isothermal surface as a function of time

35-39. Graphs showing:

35. Thermal conductivity at $35^{\circ} \mathrm{C}$ of air-saturated Alae basalt

36. The ratio of conductivity at high temperature to conductivity at room temperature of four samples of basalt from Alae crater

37. Calculated heat capacity of Alae basalt as a function of temperature

38. Calculated diffusivity of solidified Alae basalt as a function of depth and time

39. Computed and observed temperature profiles in Alae lava lake

40. Generalized radial section showing computed position of the $1,000^{\circ} \mathrm{C}$ isotherm after 120,240 , and 360 days

\section{TABLES}

2. Rainfall at the south rim of Alae crater

3. Temperatures in Alae lava lake

4. Depths and values of maximum temperatures and of basal contact temperatures in Alae lava lake

5. Bulk density and porosity of drill core

6. Altitude of stations on the lake surface

7. Thermal conductivity of four samples of basalt from Alae crater as a function of temperature

8. Specific heats of minerals and calculated heat capacity of Alae basalt 


\title{
COOLING AND VESICULATION OF ALAE LAVA LAKE, HAWAII
}

\author{
By D. L. PeCK
}

\section{ABSTRACT}

The August 1963 eruption of Kilauea Volcano, Hawaii, left a stagnant lake of molten lava as much as $15 \mathrm{~m}$ deep in Alae pit crater. Temperatures in the lava lake, which initially were as much as $1,140^{\circ} \mathrm{C}$, were monitored by means of thermocouples in drill holes in the crust of the lake starting 7 days after the eruption and continuing until the entire lake had cooled to less than $100^{\circ} \mathrm{C} 4$ years later.

Solidification of the lake proceeded by the slow increase in thickness of crusts at the top and bottom of the lake. Crystalline basalt in the upper crust at any given time graded downward into fluid lava through a zone of partly molten crust in which temperatures and melt content increased smoothly downward. The base of the crust, defined as the horizon where yield strength abruptly decreased, was at a temperature of $1,065^{\circ} \mathrm{C} \pm 5^{\circ} \mathrm{C}$; at this temperature crystals and melt were in approximately equal abundance. The lava was completely crystallized except for a sparse silicic residuum at $980 \pm 10^{\circ} \mathrm{C}$. The thickness of upper crust and the depth of isotherms in the crust and melt increased linearly with the square root of time during the first three months. Throughout this period, the thickness of upper crust in meters was $0.00132 \sqrt{t}-0.18$, where $t$ equals time in seconds after the eruption. The lake solidified (that is, cooled to less than $1,065^{\circ} \mathrm{C}$ ) $101 / 2$ months after it had formed, and it cooled below the solidus temperature of $980^{\circ} \mathrm{C} 2 \frac{1 / 2}{2}$ months later. Two years after the eruption the maximum temperature in the lake was $672^{\circ} \mathrm{C}$. Two years later, it had fallen to $86^{\circ} \mathrm{C}$. As the lake cooled, the maximum temperature was found at steadily increasing depths; the proportionate depth was 0.6 at solidification, $0.8,2$ years after the eruption, and greater than 1.0 (that is, below the lake) 2 years later. Rainfall, which ranged from 2.0 to $3.35 \mathrm{~m} /$ year, apparently did not greatly decrease the time of solidification, but it did strongly affect temperatures in the upper crust during solidification and greatly increased the rate of postsolidification cooling. Temperatures at the basal contact of the lake were measured repeatedly in drill holes that completely pierced the lake after it solidified. Uncertainties as to the precise location of the contact in each hole limit the accuracy of the determined values, but the data indicate a maximum contact temperature of $700 \pm 15^{\circ} \mathrm{C}, 60$ percent of the initial temperature of the lake.

The molten lava in Alae vesiculated because of the exsolution of gases as it cooled and solidified. The abundance of vesicles, as determined by point counts and density measurements on drill core, decreased from 40 percent near the surface to a nearly constant 11 percent below $3 \mathrm{~m}$. Large spheroidal vesicles, which were abundant near the surface but decreased sharply in size and abundance with depth, apparently recorded degassing of the super-saturated lava during the first 100 days after the eruption. Below $6 \mathrm{~m}$ the vesicles are almost entirely minute, angular pores formed at lower tempera- tures from gas exsolved from the lava during crystallization. Because of vesiculation, the molten lava in the lake expanded as it solidified, causing the surface of the lake to extend horizontally and to rise vertically. The solidified margin, in contrast, subsided because of thermal contraction. During the year of solidification, the surface above the thick central part of the lake rose as much as $0.25 \mathrm{~m}$ whereas the margin subsided as much as $0.06 \mathrm{~m}$. Repeated surveys of the altitude of stations on the lake surface, accordingly, outlined the lens of fluid lava and partly molten crust at temperatures of more than $1,000^{\circ} \mathrm{C}$ and recorded its shrinkage with time. They show the location of the last lava to solidify and demonstrate that the lake solidified more rapidly where it thinned over a buried 1840 spatter cone. The maximum uplift during any given time interval was above the lateral edge of the $1,080^{\circ} \mathrm{C}$ isothermal surface, that is, near the crust-fluid lava interface in the lake. After the last interstitial melt in the lake had solidified in late September, 1964, the entire lake surface subsided at a rate that decreased from $0.006 \mathrm{~cm} /$ day in late 1964 to $0.003 \mathrm{~cm} /$ day between May, 1966, and September, 1967. In the first year after solidification, subsidence was greatest between the center and edge of the lake in a belt that migrated inward with time and presumedly defined the part of the lake undergoing the most rapid cooling-possibly because of the cooling effect of circulating rain water in the cooler margin of the lake.

Comparison of subsidence rates with changes in temperature in the lake indicates that the effective bulk coefficient of linear thermal expansion was $3 \pm 1 \times 10^{-6} /{ }^{\circ} \mathrm{C}$. This value is approximately one-half that of the values reported from measurements on similar rocks in the laboratory. The differences probably can be attributed to the formation of microfractures during cooling of the basalt as the result of differential thermal contraction of the constituent mineral grains and glass. Where one uses this value for the coefficient of thermal expansion and relevant temperature data, the density of molten lava in Alae in September 1963 can be calculated from the average density of drill core and the change in volume during solidification and further cooling indicated by the level surveys. The calculated value of $2.79 \pm 0.03 \mathrm{~g} / \mathrm{cm}^{3}$ is the bulk density at $1,130^{\circ} \mathrm{C}$ of fluid basaltic lava containing an estimated 15 percent crystals. The calculated density of the melt fraction itself, assuming that exsolved gases are negligible, is $2.74 \mathrm{~g} / \mathrm{cm}^{3}$.

Several thermal properties of Alae basalt were measured in the laboratory or were calculated from laboratory data on the constituent minerals. The conductivity at room temperature of basalt from Alae lava lake and of similar Hawaiian basalts decreases with increasing porosity and increases with increasing olivine content (Robertson and Peck, 1974). Conductivity at room temperature, KRT, for the relatively olivine-poor Alae basalt with air in the pores is 
related to porosity, $\phi$, by the expression $K R T=(1.929-1.554 \phi)^{2}$. Previously unpublished experimental measurements on basalt from Alae crater by Kaoru Kawada (1966) and by H. R. Shaw (1966) indicate that the conductivity of vesicular basalt increases linearly with temperature at a rate of $0.03-0.09$ percent $/{ }^{\circ} \mathrm{C}$, presumedly because of radiative heat transfer across the vesicles, convective heat transfer by air in the vesicles, or progressive closing of microfractures as the result of thermal expansion of the sample during heating. The heat capacity (c) was calculated by R. A. Robie from modal and laboratory data and was fitted to the following function of temperature ( $\mathrm{T}$, in Kelvins):

$$
\mathrm{c}=0.2356+4.3635 \times 10^{-5} \mathrm{~T}-6.3440 \times 10^{3} / T^{2} .
$$

Thermal diffusivity varied in the cooling lava lake with time and depth. Calculated values typically increased from about $0.005 \mathrm{~cm}^{2} /$ sec near the surface to $0.006 \mathrm{~cm}^{2} / \mathrm{sec}$ at depths below $2-5 \mathrm{~m}$. The latent heat of completely crystalline Alae basalt, as calculated from experimentally determined heats of fusion of the constituent minerals (and the normative minerals in the glass) is 94 to $85 \mathrm{cal} / \mathrm{g}$. The calculated latent heat that was released during crystallization in the lake, however, would have been almost 20 percent less than that value, $77-67 \mathrm{cal} / \mathrm{g}$, as the result of the crystallization prior to eruption of 13 percent olivine, pyroxene, and plagioclase and the retention of nearly 7 percent silicic residuum at the end of crystallization.

The cooling history of the lake was analyzed by comparing measured temperature profiles with profiles computed on the basis of numerical analysis of one- and two-dimensional lava lake cooling models. Measured temperature profiles in the central part of the lake can be approximated with one-dimensional models that use a constant density for the basalt, a constant diffusivity of $0.006 \mathrm{~cm}^{2} / \mathrm{sec}$, and the calculated heat loss of $620 \mathrm{cal} / \mathrm{cc}$ from heating and vaporization of the measured rainfall. A better corresponcience is obtained using more complex models incorporating variable thermal and physical properties for the basalt. In the computations, diffusivity was allowed to vary with the calculated increase of heat capacity with temperature, with the measured increase in density with increasing depth in the lake, and with variations of conductivity with temperature and basalt vesicularity. Heat loss by heating and vaporization of rain water was computed using the measured density structure of the lake. Low values for density and conductivity were given to a shallow cell in the lake to simulate the highly vesicular and cavernous zone found at depths between $0.3-1.2 \mathrm{~m}$. The closest match of computed and observed temperatures was obtained using a latent heat of $80 \pm 10 \mathrm{cal} / \mathrm{g}$ (from 80 percent crystallization) and conductivity $(K T)$ that was related to temperature, $T^{\circ} \mathrm{C}$, and conductivity at room temperature, $K R T$, by the expression $K T=K R T(1+\beta T)$, where $B$ equals $0.0006 \pm 0.0001$. In the computations, 10 representative profiles measured during the first year of cooling were matched at 1 -foot $(0.3 \mathrm{~m})$ intervals with an average deviation of $2^{\circ} \mathrm{C}$.

Computations using two-dimensional models confirmed the lateral variations with time of temperatures in the lake inferred from temperature measurements in drill holes and precise level studies, and indicate that temperatures in the lake were decreased more than $1^{\circ} \mathrm{C}$ by marginal cooling during the first year only in the outer $15 \mathrm{~m}$ of the lake, and in the fourth year only in the outer $45 \mathrm{~m}$. Computations using "rain" and "no rain" models indicate that the lake had cooled to $100^{\circ} \mathrm{C}$ by mid-April $1967,4 \frac{1}{2}$ months before the final temperature measurements. Without rain the lake would have taken 19.5 years to cool to $100^{\circ} \mathrm{C}$.

\section{INTRODUCTION}

Six days after the August 1963 eruption of Kilauea Volcano, Hawaii, had formed a shallow lake of basaltic lava in Alae crater, a hole was drilled $0.86 \mathrm{~m}$ into the crust of the lake to within $0.01 \mathrm{~m}$ of the molten lava.
Temperatures were measured in the drill hole the following day, and a grid of stations was established over the surface of the lake. During the ensuing year of solidification of the lava lake and the following 3 years of cooling to less than $100^{\circ} \mathrm{C}$, several additional holes were drilled in the lake, temperatures were measured repeatedly, and the relative altitudes of the stations were periodically redetermined. These measurements provide a unique body of data on the rate and pattern of cooling of a ponded basaltic lava flow. Data from additional measurements on drill core from the lake, including density, vesicularity, and thermal conductivity, together with thermal coefficients calculated from the modal mineral composition of the core, were used in detailed comparison of the observed cooling history with numerical cooling models.

This report is the second of three chapters describing the recorded history of Alae lava lake. Chapter A describes the eruption of August 1963, and the surface features of the lava lake including joint cracks. Chapter C (Wright and Peck, 1978) presents the results of chemical and petrographic studies of pumice from the eruption and drill core from the lake. Aspects of the cooling history of the Alae lava lake have been described in the following preliminary reports: Peck, Moore and Kojima (1964) reported temperature measurements in the lake through February, 1964; Peck, Wright, and Moore (1966) described the crystallization of basalt in the lake; Decker and Peck (1967) analyzed infrared temperatures at the lake surface. Shaw, Hamilton, and Peck (1977) formulated numerical models for the cooling history of lava lakes, which were applied to Alae lava lake by Peck, Hamilton, and Shaw (1977). Temperature measurements in other recent Kilauean lava lakes are reported by Ault, Eaton, and Richter (1961), Ault, Richter, and Stewart (1962), Rawson (1960), Richter and Moore (1966), Wright, Kinoshita, and Peck (1968), and Wright and Okamura (1977). Wright, Peck, and Shaw (1976) summarize studies made on all three Kilauean lava lakes.

Alae crater was one of several pit craters on the upper east rift zone of Kilauea Volcano, Island of Hawaii. I refer to the crater and the August 1963 lava lake in the past tense because the lava lake was buried by eruptions starting in February 1969 (Swanson and others, 1971) and the crater was later completely filled with lava and the site covered by a broad, 100-m-high basaltic dome satellitic to the new shield Mauna Ulu (Swanson and others, 1973; Swanson and Peterson, 1972). The crater was about $8 \mathrm{~km}$ southeast of the summit caldera, and in 1963 was adjacent to the hardsurface Chain-of-Craters Road (Peck and Kinoshita, 1976, fig. 2). The surface of the lava lake was $150 \mathrm{~m}$ below the rim of the crater and could be reached by a 
rude trail assisted by ropes over the steeper parts. Because of the steepness of the trail, an aerial tram into the crater was constructed for lowering equipment and water soon after the August 1963 eruption, before a program of drilling and other studies was started.

The eruption that formed the August 1963 lava lake lasted from $18 \mathrm{~h} 10 \mathrm{~m}^{1}$ August 21 to $08 \mathrm{~h} 10 \mathrm{~m}$ August 23. The bulk of the lava in the lake was erupted during the first few hours, when fountains on the floor and north wall of the crater fed lava into the lake at rates as great as $2.3 \times 10^{5} \mathrm{~m}^{3}$ per hour and maximum temperatures of about $1,160^{\circ} \mathrm{C}$. During the last 12 hours of the eruption, the rate of extrusion dropped to near zero and maximum temperatures fell to $1,140^{\circ} \mathrm{C}$. Near the end of the eruption, $1.8 \times 10^{5} \mathrm{~m}^{3}$ of lava drained back into the vents, leaving a stagnant lake containing $6.6 \times$ $10^{5} \mathrm{~m}^{3}$ of homogeneous tholeiitic basalt. The lake was an elliptical lens $305 \mathrm{~m}$ long, $245 \mathrm{~m}$ wide, and as much as $15 \mathrm{~m}$ deep. The outline of the lake, contours at the base and margin, and the location of surveying stations and drill holes are shown in figure 1 , together with cross sections along the major and minor axes.

All but the northwest end of the lake was bordered by a levee of strongly jointed, discontinuous pressure ridges, and the levee was bounded for most of its length by a moat $8-15 \mathrm{~m}$ wide and about $2 \mathrm{~m}$ deep. The lake within the levee had a hummocky surface that sloped almost imperceptibly toward the vent at the north end of the lake. The surface was nearly flat having an average relief of less than $0.3 \mathrm{~m}$, but it was crossed by sharp pressure ridges and linear ooze ups that stood as high as $1 \mathrm{~m}$ above the lake surface. The lake deepened sharply inward from the edge to an average maximum depth of $14.0 \mathrm{~m}$. The base of most of the lake was also nearly flat, but it sloped at a small angle to a low area beneath the north-central part of the lake, and the lake thinned to $11.3 \mathrm{~m}$ over a buried spatter ridge formed during the eruption of 1840 . The lake surface was broken by a network of joint cracks, some of which were opened during the later part of the eruption to form gaping crevasses as much as $30 \mathrm{~cm}$ wide and $2 \mathrm{~m}$ deep (Peck and Kinoshita, 1976, fig. 31). Other joint cracks formed as the result of thermal contraction during later cooling of the lake (Peck and Minakami, 1968).

Solidified lava from depths below $1.5 \mathrm{~m}$ in the lake is homogeneous gray basalt containing sparse olivine phenocrysts in a fine-grained intergranular groundmass. The average modal composition in weight percent (Wright and Peck, 1978) is olivine, 3.5; clinopyroxene, 42.1; plagioclase, 41.6; ilmenite, 4.4; magnetite, 1.0; apatite, 0.65; and clear residual glass, 6.75. The Alae basalt is a tholeiite having a very uni-

${ }^{1}$ Al! times given are in hours and minutes. Hawaii Standard Time. form bulk chemical composition as follows (in weight percent): $\mathrm{SiO}_{2}, 50.47 ; \mathrm{Al}_{2} \mathrm{O}_{3}, 13.67 ; \mathrm{Fe}_{2} \mathrm{O}_{3}, 1.30 ; \mathrm{FeO}$, 9.80; $\mathrm{MgO}, 7.55 ; \mathrm{CaO}, 11.11 ; \mathrm{Na}_{2} \mathrm{O}, 2.38 ; \mathrm{K}_{2} \mathrm{O}, 0.54$; $\mathrm{TiO}_{2}, 2.74 ; \mathrm{P}_{2} \mathrm{O}_{5}, 0.27 ; \mathrm{MnO}, 0.17$.

\section{ACKNOWLEDGMENTS}

The study of Alae lava lake was a team effort by the staff of the Geological Survey's Hawaiian Volcano Observatory. It was started under the direction of Scientist-in-Charge, James G. Moore, and was completed under his successor, Howard A. Powers. Thomas L. Wright helped in all aspects of the field studies. In the gathering of the temperature data, I am particularly indebted to the following staff members: George Kojima, who constructed the thermocouples; William Francis, Reginald Okamura, Eliot Endo, and Willie Kinoshita, who helped in the drilling and in the temperature measurements; Burton Loucks, who made much of the special equipment used in the study; and John Forbes, who made the rainfall measurements. The continuous recording of temperatures in drill holes in the lake was a joint effort with a visiting group of scientists and technicians from Japan that included Profs. T. Minakami, D. Shimozuru, S. Aramaki, and K. Kamo, and Messrs. T. Miyasaki and S. Hiraga. Dr. Aramaki also helped in the drilling. Reginald Okamura and Eliot Endo helped with the level surveys and made most of the measurements of bulk and grain density. Analysis of the temperature data was made possible by the laboratory measurements of thermal properties by E. C. Robertson, Prof. Kaoru Kawada, and Joel H. Swartz and by the numerical analysis by Prof. J. C. Jaeger, H. R. Shaw, and M. S. Hamilton. R. A. Robie, D. R. Wones, and H. S. Yoder supplied essential data on other thermal properties.

\section{METHODS OF STUDY DRILLING}

Holes were drilled in the solidified crust of the lava using tungsten carbide bits in a portable core drill powered by a 9-horsepower gasoline engine (fig. 2). Most of the holes were $2.86 \mathrm{~cm}$ in diameter, yielding $1.43 \mathrm{~cm}$ diameter core, but the upper part of one hole (drill hole 9) was drilled to $3.8 \mathrm{~cm}$ diameter with EX bits. Twelve holes were drilled during the 15 months following the eruption; the holes had a total depth of $100 \mathrm{~m}$. Dates and depths of drilling are given in table 1 , and the location of the holes are plotted in figure 1. A total of about $18 \mathrm{~kg}$ of core was recovered from the lake during the drilling. All except the first two holes were drilled by mounting the drill on a portable mast anchored in the crust and cooling the bits by means of water pumped through the drill pipe by a portable $3 \frac{114}{4}$ horsepower gasoline engine. The water was fed 

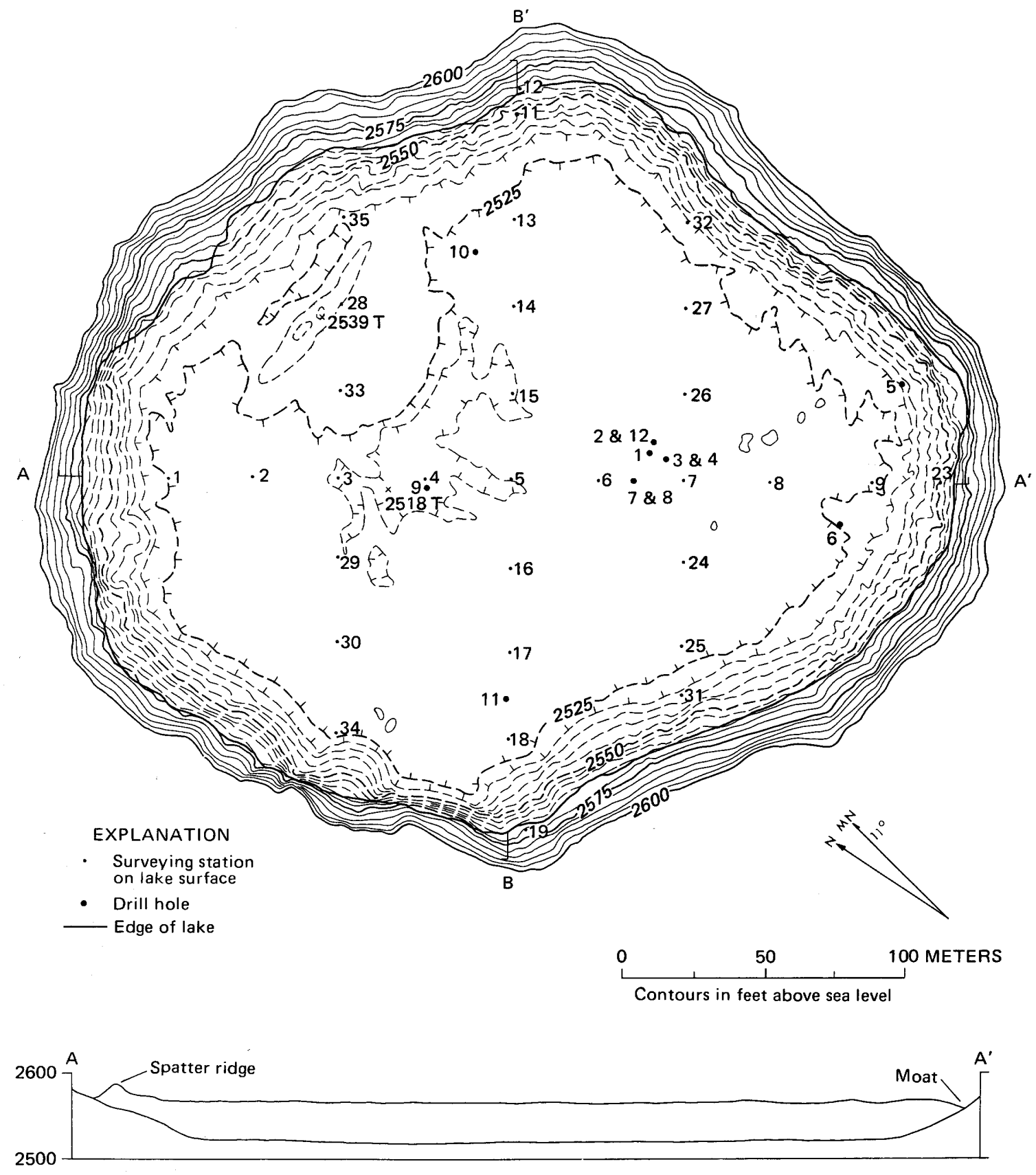

FEET ABOVE

SEA LEVEL

O 25 METERS

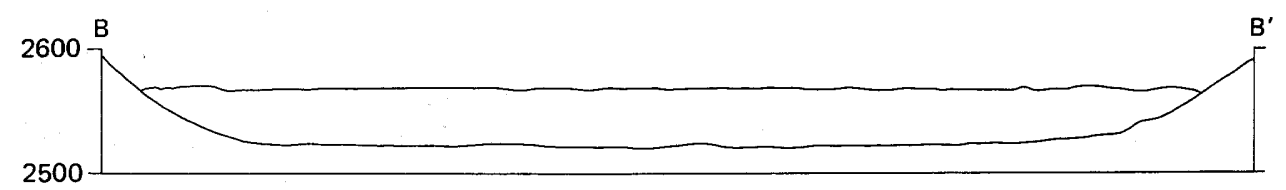

FEET ABOVE

SEA LEVEL

Figure 1.- Map of Alae lava lake showing contours at the base and margin and the location and identification number of surveying stations and drill holes. Cross sections along the major axis (A-A') and the minor axis ( $\left.\mathrm{B}-\mathrm{B}^{\prime}\right)$ of the lake have the same horizontal and vertical scale. The structure beneath the northern part of the lake is a buried spatter ridge formed in the 1840 eruption. Topography prepared by photogrammetric methods from aerial photographs taken February 15, 1963, by the U.S. Geological Survey. 


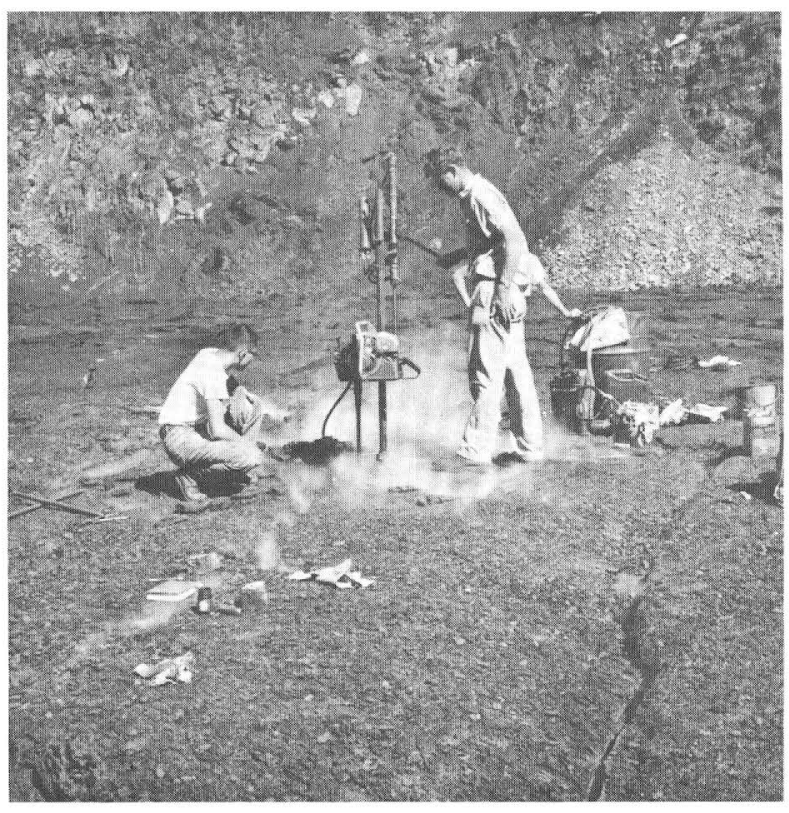

Figure 2.-Drilling in Alae lava lake, November 1963. The mast-mounted, portable drill is forced downward by applying pressure to a lever arm. Coolant water pumped through the drill stem turns to steam in the hot crust of the lake and rises along joint cracks in the drilling area.

through hoses from the rim of the crater and stored in a 50-gallon (190 liter) steel drum near the drilling site. About 100 liters of water were used for each linear meter of drilling. The first two holes were drilled by holding the drill and pouring water into the hole by hand.

Seven of the holes were drilled through the crust and into the underlying molten lava. In each hole, the drill fell under its own weight when the drill bit reached the base of the upper crust. When the drill stem was withdrawn, in most instances, superheated steam blasted up through the drill hole, sounding like a jet engine and continuing for as long as 12 minutes. In one hole, temperatures of $675^{\circ} \mathrm{C}$ were measured in the water vapor, and the collar of the drill hole was heated to glowing red. Four holes were drilled through the center of the lake and into the lower crust to near the basal contact, and core of the underlying 1840 lava was recovered from one of these (DH 9).

Drilling rates averaged $1 \mathrm{~m}$ an hour when all equipment was working properly. Most of the drilling, however, was slowed by mechanical failure of the water pump or drill. All equipment used on the lake corroded at an accelerated rate because of the high temperatures and rainfall and the abundance of sulfur in gases from the lake.

\section{TEMPERATURE MEASUREMENTS}

Temperatures in drill holes were measured repeatedly during the 4-year study of the cooling lake.
TABLE 1.-Record of drill holes in Alae lava lake

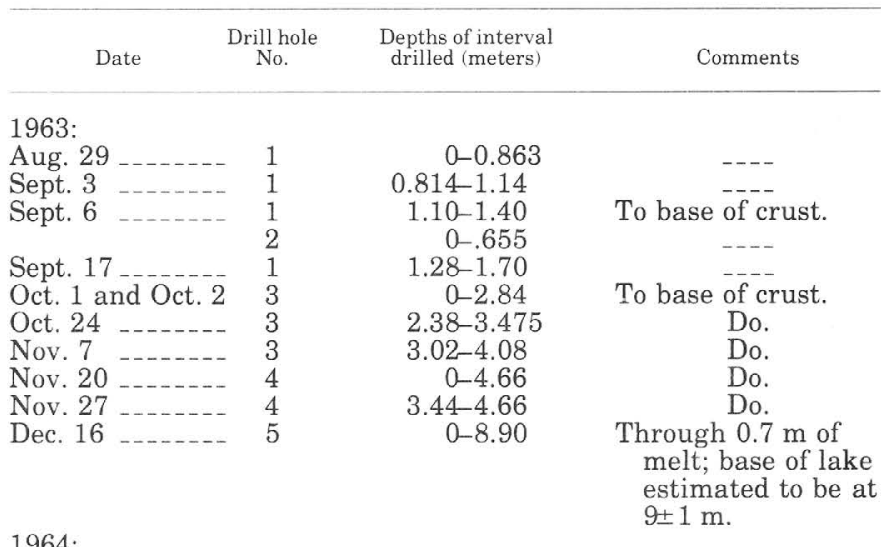

$1964:$

Apr. 1 and Apr. 2

$5.33-6.40$

$0-9.83$

Apr. 15 6

$5.41-13.05$

Apr. 22

$5.91-10.7$

Apr. 22

Apr. 29

June 4

June 10

June 17

June 18

6
7
7
7
8

July 28

July 29

Sept. 11 -

6

$0-0.25$

$0-0.25$
$0-6.1$

6.00-6.64

$6.51-7.13$

$0-6.325$

$6.325-8.73$

0-3.57

$3.57-3.87$

3.87-6.92

Oct. 20

9

$10.52-16.12$

Plug of ooze.

Through $2 \mathrm{~m}$ of melt into lower crust.

Through plug of ooze and lower crust to near base of lake.

Through plug of ooze.

Mast hole.

$-\cdots$

Through $0.3 \mathrm{~m}$ of melt into lower crust.

Through partly molten center of lake into lower crust.

Through base of lake at approximately $14.5 \mathrm{~m}$ and into 1840 lava (cored between 14.6 and $15.2 \mathrm{~m}$ ).

$\begin{array}{lrr}\text { Oct. } 22 \ldots & 10 & 0-4.9 \\ & 11 & 0-2.7 \\ \text { Nov. } 17 \ldots & 11 & 2.7-4.9 \\ \text { Nov. } 19 \ldots-4.79 \\ \end{array}$

-

$---$

Through base of lake at approximately $13.7 \mathrm{~m}$ (inferred from presence of cavernous layer between 13.1 and $14.3 \mathrm{~m}$ ).

Note.-Location of drill holes:

1. Near the major axis of the lava lake on the opposite side from the vents, $50.3 \mathrm{~m} \mathrm{~S} 44^{\circ} \mathrm{E}$ of the center of the lake (fig. 1); altitude of collar 2,567.2 feet $(782.48 \mathrm{~m})$ on Feb. 10 , 1964 .

2. $4.88 \mathrm{~m} \mathrm{~N} 75^{\circ} \mathrm{E}$ of drill hole 1 ; altitude of collar $2,567.3$ feet $(782.51 \mathrm{~m})$ on Feb. 10,1964 3. $6.1 \mathrm{~m} \mathrm{~S} 15^{\circ} \mathrm{E}$ of drill hole 1 ; altitude of collar $2,567.3$ feet $(782.51 \mathrm{~m})$ on Feb. 10, 1964 4. $0.3 \mathrm{~m} \mathrm{~N} 75^{\circ} \mathrm{E}$ of drill hole 3; altitude of collar 2,567.3 feet $(782.51 \mathrm{~m})$ on Feb. 10, 1964 5. $93.0 \mathrm{~m} \mathrm{~S} 49^{\circ} \mathrm{E}$ of drill hole 1 ; altitude of collar $2,565.8$ feet $(782.06 \mathrm{~m})$ on Feb. 10,1964 6. $73.2 \mathrm{~m} \mathrm{~S} 17^{\circ} \mathrm{E}$ of drill hole 1; altitude of collar $2,567.4$ feet $(782.54 \mathrm{~m})$ on Sept. 24,1964 7. $11.0 \mathrm{~m} \mathrm{~S} 85^{\circ} \mathrm{W}$ of drill hole 1; altitude of collar 2,566.9 feet $(782.39 \mathrm{~m}$ ) on May 12,1964 8. $0.3 \mathrm{~m} \mathrm{SW}$ of drill hole 7; altitude of collar 2,566.9 feet (782.39 m) on May 12, 1964

9. $79.2 \mathrm{~m} \mathrm{~N} 42^{\circ} \mathrm{W}$ of drill hole 1 ; altitude of collar $2,567.5$ feet $(782.57 \mathrm{~m}$ l on July 31,1964 10. $94.5 \mathrm{~m} \mathrm{~N} 16^{\circ} \mathrm{E}$ of drill hole 1: altitude of collar $2,568.0$ feet $(782.73 \mathrm{~m}$ । on Nov. 3,1964 11. $100.6 \mathrm{~m} \mathrm{~S} 87^{\circ} \mathrm{W}$ of drill hole 1: altitude of collar $2,566.9$ feet $(782.39 \mathrm{~m}$ ) on Nov. 3, 1964 12. $0.7 \mathrm{~m}$ due east of drill hole 2 : altitude of collar $2,567.5$ feet $(782.57 \mathrm{~m})$ on Jan. 21,1965 
Most of the measurements were made with stainlesssteel-sheathed thermocouples of heavy-gage chromelalumel, using a portable millivolt potentiometer and a $0^{\circ} \mathrm{C}$ reference junction in an ice-filled vacuum bottle. Temperatures of the lake surface were measured by means of a mercury thermometer. During the first few months, repeated attempts were made to measure temperatures in the holes with platinum-platinum plus 10 percent rhodium thermocouples made with fine-gage wire. Most of these attempts were unsuccessful because the wires broke near the junction immediately after inserting the thermocouple, presumedly as a result of the stress caused by thermal expansion of the steel sheathing.

The thermocouples were constructed in the $\mathrm{Ha}$ waiian Volcano Observatory by stringing 1-inch (2.54 $\mathrm{cm}$ )-long ceramic beads onto thermocouple wire, and inserting the wire and beads in $3 / 8$-inch $(0.95 \mathrm{~cm})$ O.D. stainless-steel tubing welded shut at one end. Hastalloy-C tubing proved to be most resistant to corrosion. Most of the thermocouples had five junctions, spaced 1 or 3 feet $(0.305$ or $0.914 \mathrm{~m})$ apart. Many of the thermocouples were more than $15 \mathrm{~m}$ long and required considerable care in handling. The potentiometer used in the measurements has a reproducible reading accuracy of $0.01 \mathrm{mv}$. Temperature readings of several but not all of the thermocouples were compared with those of a National Bureau of Standards platinum-platinum plus 10 percent rhodium thermocouple at the Observatory. Most of the temperature measurements probably have an accuracy of \pm 0.5 percent at $500^{\circ} \mathrm{C}$ and \pm 1 percent at $1,000^{\circ} \mathrm{C}$, but uncertainties in the depth of measurement decrease the accuracy of the recorded temperatures. The depth of the thermocouple junctions in the drill holes was determined by marking each thermocouple sheathing, using a steel tape, and were recorded to an accuracy of \pm 0.05 feet $(1.5) \mathrm{cm}$ ). Thermal expansion of the sheathing of thermocouples made accurate depth measurements in the deeper holes difficult; thermocouples inserted rapidly to the bottom of the $15 \mathrm{~m}$ holes expanded as much as $6 \mathrm{~cm}$ within a few minutes.

Each thermocouple could be used only a few times because of corrosion of the sheathing which allowed sulfur- and water-rich gases given off by the cooling basalt to come in contact with the thermo-couple wires. These gases reacted rapidly with the chromel wire, destroying continuity in the thermocouple. During times of heavy rains, water collected within the sheathing of the thermocouples left on the lava lake. When these were subsequently used in the drill holes, steam caused shorting between the wires. Consistent readings could not be obtained until the entire length of the thermocouple was baked dry in a deep drill hole in the hot lake.
In several drill holes, temperatures were measured both in the crust and in the underlying melt. Measurements in the melt were achieved by attaching a ceramic probe to the drill string and pushing it into the melt through the bottom of a drill hole after drilling through the base of the crust. Temperatures were then measured with a thermocouple inserted into the drill string and probe. Probes as long as $3.0 \mathrm{~m}$ were constructed from $0.75 \mathrm{~m}$ lengths of 2.5-cm O.D. mullite tubes (the lower one closed at one end), were joined with $10-\mathrm{cm}$ sleeves cemented with silica cement, and were attached to the drill steel with a machined fitting. The whole unit was placed in the drill hole after drilling was completed, and the temperature in the bottom of the drill hole was measured by means of a thermocouple inserted in the probe. After the temperature had reached $1,065^{\circ} \mathrm{C}-1,070^{\circ} \mathrm{C}$, the unit could be pushed slowly into the melt. Sometimes, but not always, it could also be pulled out. Use of excessive pressure caused cracking of the probes, allowing melt to enter. An unbroken probe was not emplaced into the melt successfully until December 2, 1963, after six unsuccessful attempts over the preceding 3 months. Later work in the 1965 lava lake in Makaopuhi crater has shown that stainless-steel probes can be used successfully for long periods in the melt, and they can be emplaced with far less hazard of breakage.

MEASUREMENTS OF THE ALTITUDE OF THE LAKE SURFACE

On August 30, 1963, 17 stations were laid out at 100 -foot $(30.48 \mathrm{~m})$ intervals along the major and minor axes of the lake by means of a transit and steel tape (fig. 1), and 2 additional stations (12 and 19) were marked by chiseling squares on the highest parts of 2 talus blocks at the ends of the minor axis. This grid was augmented in mid-September with 12 stations along two cross lines parallel to and 200 feet $(60.96 \mathrm{~m})$ from the minor axis. A few additional stations were added during the following year. The stations were marked by driving $5 \mathrm{~cm}$ concrete nails into the crust through stamped copper and aluminum tags. Distances between stations were measured on August 30 to \pm 1.5 $\mathrm{cm}$; during the following year they were remeasured several times with more care to $\pm 0.3 \mathrm{~cm}$. Relative altitudes of the stations with respect to station 19 on the talus were determined with a fiberglass stadia rod and a surveyor's transit (using the transit as a level by means of the striding bubble); later, a self-leveling surveyor's level was used. Relative altitudes of the stations were measured 21 times during the 4 years of study-at 2 -week intervals during the first month, 1-month intervals during the following year, approximately 3-month intervals during the second year, and finally, on days near the end of the third and fourth 
years. With few exceptions, all level lines were closed and the errors distributed.

The measurements of altitudes on August 30, 1963, were taken with a damaged transit and may be in error by as much as $1.5 \mathrm{~cm}$. Later altitudes relative to the stations on the talus are accurate to $\pm 0.2 \mathrm{~cm}$, and the use of the surveyor's level after September, 1964, reduced the error to about $\pm 0.1 \mathrm{~cm}$. The relative altitudes of stations on the surface of the lake were measured relative to the rim of the crater to $\pm 0.3 \mathrm{~m}$ by resection and vertical angle with a transit from two stations on the rim joined by a taped base line.

\section{PRECIPITATION AND AIR TEMPERATURES}

Alae crater is within the rain forest that blankets the northeast slope of Kilauea Volcano. Some rain falls during all but a few weeks each year, but most of the precipitation comes during "Kona" (southerly) storms in the fall and winter. Precipitation was monitored by means of a continuously recording rain gage at the south rim of the crater from September 12, 1963, to March 18, 1965, and also by means of a standard gage at the same location from November 16, 1964, through September 1967.

Rainfall during the 4 years covered by this report varied from $200 \mathrm{~cm}$ to $335 \mathrm{~cm}$ per year and totaled $1,012 \mathrm{~cm}$. The recorded precipitation for weekly intervals is given in table 2 .

Air temperatures were recorded at Alae crater only during September, 1963. From September 12 to October 1,1963 , the temperature at the south rim ranged fro $17.1^{\circ}$ to $25.5^{\circ} \mathrm{C}$ and averaged $19.8^{\circ} \mathrm{C}$.

An average air temperature during the years that the Alae lava lake cooled can be estimated from recordings at Hawaii Volcanoes National Park Headquarters. From October 1963 through September 1966, temperatures there ranged from $5^{\circ} \mathrm{C}$ to $26^{\circ} \mathrm{C}$ and averaged $15.6^{\circ} \mathrm{C}$. As the mean temperature on the island of Hawaii falls at the rate of about $1^{\circ} \mathrm{C}$ per $150 \mathrm{~m}$ rise in altitude (Stearns and Macdonald, 1946, p. 209), the mean air temperature during that period at the rim of Alae, which is $300 \mathrm{~m}$ lower than Park Headquarters, was probably about $18^{\circ} \mathrm{C}$.

\section{TEMPERATURES IN THE LAVA LAKE}

Temperatures in Alae lava lake were monitored by means of thermocouples in drill holes on 47 separate days over a 4 year period beginning 7 days after the eruption. Measured temperatures ranged from $16^{\circ} \mathrm{C}$ at the surface of the lake margin during the early morning of December 18,1964 , to $1,135^{\circ} \mathrm{C}$ in molten lava $2.3 \mathrm{~m}$ below the crust of the lake on November 8, 1963 . The lake solidified (cooled to less than $1,065^{\circ} \mathrm{C}$ ) by mid-
July $1964,10^{1 / 2}$ months after the eruption, and the last interstitial melt solidified by late September 1964, 21/2 months later. The entire lake cooled to less than $100^{\circ} \mathrm{C}$ in less than 4 years, as shown by the last measured temperature profile on August 31, 1967. Five representative temperature profiles, including the first and last ones, measured, are shown in figure 3 , and selected temperature data are given in table 3 . These are mostly from temperature profiles least affected by coolant water used during drilling and not affected by failing thermocouples, but include some data showing the chilling effect of coolant water and later thermal recovery of the crust.

\section{DEFINITION OF CRUST AND FLUID LAVA}

While it solidified, Alae lava lake, like other recent Kilauean lava lakes, consisted of a fluid interior and upper and lower crusts. Above the base of the upper crust (and below the top of the lower) was a broad zone of partly molten crust in which temperatures and abundance of the melt fraction increased smoothly downward from completely solidified crust to fluid lava containing subordinate crystals (Richter and Moore, 1966; Wright and others, 1968). The zone extended from a temperature of $980^{\circ} \mathrm{C}$ downward to the base of the crust at $1,065^{\circ} \mathrm{C}$, at which temperature the yield strength of the lava abruptly decreased. At progressively greater depths below the upper crust, the abundance of crystals in the fluid lava steadily decreased to the depth of the maximum temperature in the lake.

When the base of the crust was penetrated in drilling, the lava no longer offered strong resistance to the drill, and the drill fell under its own weight. In the six complete penetrations of the base of the crust in Alae, the horizon at which failure took place was between 0.1 and $1 \mathrm{~m}$ below the depth of the $1,065^{\circ} \mathrm{C}$ isotherm and at a temperature (before drilling) of between $1,070^{\circ} \mathrm{C}$ and $1,100^{\circ} \mathrm{C}$. During drilling, the environment at the base of the crust was complex. As the drill penetrated the zone of crystallization, coolant water pumped through the drill stem quenched the melt fraction of the enclosing lava to glass until a level was reached where lava temperatures were so great that little or no selvage of glass was formed. The exact temperature of this horizon as reconstructed from temperature profiles measured before and after drilling varied from one drilling operation to another, depending on the rate of drilling and amount of coolant water used.

After the base of the crust was penetrated by drilling in this way, a hollow probe could be pushed through the drill hole and into the underlying fluid lava. After each penetration we had to wait some time until the quenched lava at the base of the hole had become sufficiently warmed, a period ranging from a few hours 
TABLE 2.-Rainfall at the south rim of Alae crater

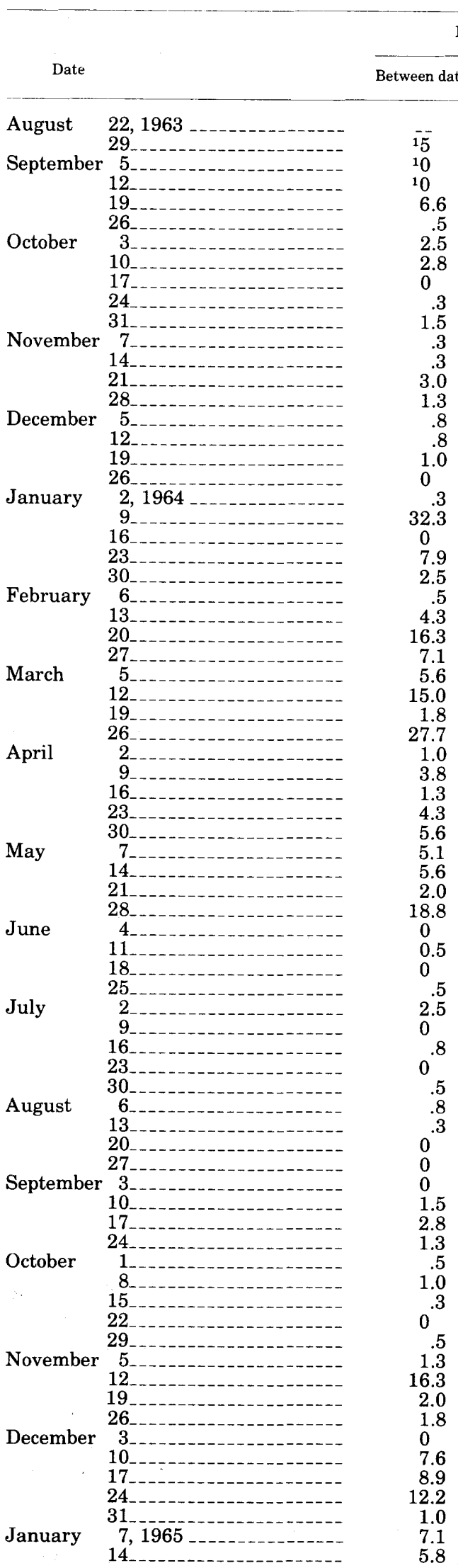

TABLE 2.-Rainfall at the south rim of Alae crater-Continued

\begin{tabular}{|c|c|c|c|}
\hline & & Rain & \\
\hline Date & & Between dates & Total \\
\hline January & 21 & 2.8 & 276.1 \\
\hline & 28 & 7.1 & 283.2 \\
\hline February & 4 & 0 & 283.2 \\
\hline & $111_{---}$ & 2.0 & 285.2 \\
\hline & 18 & .8 & 286.0 \\
\hline & 25 & .3 & 286.3 \\
\hline March & 4 & .3 & 286.6 \\
\hline & $11-\ldots$ & 4.1 & 290.7 \\
\hline & $16 \ldots$ & 0 & 290.7 \\
\hline & 22 & 6.4 & 297.1 \\
\hline & 29 & 3.8 & 300.9 \\
\hline April & 5 & 19.1 & 320.0 \\
\hline & 12 & 14.2 & 334.2 \\
\hline & 19 & 31.8 & 366.0 \\
\hline May & 26 & 1.8 & 367.8 \\
\hline May & $3-$ & 10.9 & 378.7 \\
\hline & $10 \ldots$ & 43.2 & 421.9 \\
\hline & $17 \ldots$ & 4.1 & 426.0 \\
\hline & 24 & 3.6 & 429.6 \\
\hline & $31 \ldots$ & 3.3 & 432.9 \\
\hline June & $7 \ldots$ & 3.0 & 435.9 \\
\hline & 14 & 1.5 & 437.4 \\
\hline & - & 1.3 & 438.7 \\
\hline & $28 \ldots$ & 1.5 & 440.2 \\
\hline July & 6 & .8 & 441.0 \\
\hline & $13_{--}$ & 1.5 & 442.5 \\
\hline & $19_{-\ldots}$ & 2.8 & 445.3 \\
\hline & $26 \ldots$ & 2.3 & 447.6 \\
\hline August & 4 & 1.5 & 449.1 \\
\hline & 9 & 1.0 & 450.1 \\
\hline & 16 & 1.0 & 451.1 \\
\hline & 23 & 1.8 & 452.9 \\
\hline & $30 \ldots$ & .3 & 453.2 \\
\hline September & $7 \ldots$ & .5 & 453.7 \\
\hline & $13_{-}$ & 9.9 & 463.6 \\
\hline & 20 & 1.3 & 464.9 \\
\hline & $27 \ldots$ & .5 & 465.4 \\
\hline October & 4 & .8 & 466.2 \\
\hline & $11 \ldots$ & 3.0 & 469.2 \\
\hline & -............ & 5.3 & 474.5 \\
\hline & $25_{\ldots} \ldots$ & 9.4 & 483.9 \\
\hline November & $1 \ldots$ & .3 & 484.2 \\
\hline & $8 \ldots$ & 9.4 & 493.6 \\
\hline & $15 \ldots$ & 46.5 & 540.1 \\
\hline & $22 \ldots$ & 4.8 & 544.9 \\
\hline & 29 & 3.6 & 548.5 \\
\hline December & 6 & 1.5 & 550.0 \\
\hline & $20 \ldots \ldots$ & 15.7 & 565.7 \\
\hline January & 5,1966 & 4.3 & 570.0 \\
\hline & 10 & 1.3 & 571.3 \\
\hline & 17 & 1.0 & 572.3 \\
\hline & 24 & 3.8 & 576.1 \\
\hline & $31 \ldots$ & 3.6 & 579.7 \\
\hline February & $7 \ldots$ & 9.4 & 589.1 \\
\hline & $15 \ldots$ & 9.4 & 598.5 \\
\hline & $21 \ldots$ & 3.6 & 602.1 \\
\hline & $28 \ldots$ & 0.5 & 602.6 \\
\hline March & 7 & .8 & 603.4 \\
\hline & 14 & .3 & 603.7 \\
\hline & 21 & 8.4 & 612.1 \\
\hline & 28 & 1.5 & 613.6 \\
\hline & 31 & .5 & 614.1 \\
\hline April & $11-2$ & 4.3 & 618.4 \\
\hline & 18 & 2.3 & 620.7 \\
\hline & 25 & 2.0 & 622.7 \\
\hline May & 2 & 4.3 & 627.0 \\
\hline & $\mathbf{9}_{-}$ & .8 & 627.8 \\
\hline & 16 & 9.4 & 637.2 \\
\hline & 23 & 1.3 & 638.5 \\
\hline June & 31 & 2.8 & 641.3 \\
\hline June & 6 6 & 1.8 & 643.1 \\
\hline & 20 & $\begin{array}{l}1.3 \\
1.5\end{array}$ & $\begin{array}{l}644.4 \\
645.9\end{array}$ \\
\hline & & 41 & 6500 \\
\hline
\end{tabular}


TABLE 2.-Rainfall at the south rim of Alae crater-Continued

\begin{tabular}{|c|c|c|c|}
\hline & & \multicolumn{2}{|c|}{ Rainfall (cm) } \\
\hline \multicolumn{2}{|l|}{ Date } & Between dates & Total \\
\hline \multirow[t]{4}{*}{ July } & 5 & 5.1 & 655.1 \\
\hline & $11 \ldots$ & .8 & 655.9 \\
\hline & 18 & 5.6 & 661.5 \\
\hline & & 7.6 & 669.1 \\
\hline \multirow[t]{5}{*}{ August } & 1 & 1.5 & 670.6 \\
\hline & 8 & 1.0 & 671.6 \\
\hline & 15 & .5 & 672.1 \\
\hline & 22 & 4.6 & 676.7 \\
\hline & 29 & 3.3 & 680.0 \\
\hline \multirow{4}{*}{ September } & 6 & 2.0 & 682.0 \\
\hline & 12 & 3.0 & 685.0 \\
\hline & 19 & 4.6 & 689.6 \\
\hline & 26 & 9.7 & 699.3 \\
\hline \multirow[t]{5}{*}{ October } & 3 & 5.3 & 704.6 \\
\hline & $10_{--}$ & 1.0 & 705.6 \\
\hline & 17 & 15.0 & 720.6 \\
\hline & 24 & 3.8 & 724.4 \\
\hline & 31 & .8 & 725.2 \\
\hline \multirow{4}{*}{ November } & 7 & 35.6 & 760.8 \\
\hline & 15 & 2.0 & 762.8 \\
\hline & 21 & 5.8 & 768.6 \\
\hline & 28 & 18.0 & 786.6 \\
\hline \multirow{4}{*}{ December } & 5 & 1.5 & 788.1 \\
\hline & $12_{--}$ & 5.1 & 793.2 \\
\hline & 19 & 2.5 & 795.7 \\
\hline & 27 & 4.3 & 800.0 \\
\hline \multirow[t]{5}{*}{ January } & 3,1967 & 22.1 & 822.1 \\
\hline & 9 & 1.5 & 824.6 \\
\hline & 16 & 4.6 & 829.2 \\
\hline & 23 & 1.3 & 830.5 \\
\hline & 31 & 1.0 & 831.5 \\
\hline \multirow[t]{4}{*}{ February } & 3 & 1.0 & 832.5 \\
\hline & $14 \ldots$ & 14.0 & 846.5 \\
\hline & 20 & 3.0 & 849.5 \\
\hline & 27 & .5 & 850.0 \\
\hline \multirow[t]{4}{*}{ March } & 6 & 4.6 & 854.6 \\
\hline & $13_{--}$ & 6.4 & 861.0 \\
\hline & 20 & 13.7 & 874.7 \\
\hline & 27 & 10.2 & 884.9 \\
\hline \multirow[t]{4}{*}{ April } & 3 & 8.1 & 893.0 \\
\hline & 11 & 7.4 & 900.4 \\
\hline & 17 & 7.6 & 908.0 \\
\hline & 24 & 7.6 & 915.6 \\
\hline \multirow[t]{6}{*}{ May } & 1 & 4.3 & 919.9 \\
\hline & 8 & 3.8 & 923.7 \\
\hline & 15 & 20.3 & 944.0 \\
\hline & - & 1.0 & 945.0 \\
\hline & 29 & 2.0 & 945.0 \\
\hline & 29 & 2.0 & 947.0 \\
\hline \multirow[t]{4}{*}{ June } & 5 & 1.8 & 948.8 \\
\hline & 12 & 1.8 & 950.6 \\
\hline & 19 & 1.5 & 952.1 \\
\hline & 26 & 2.8 & 954.9 \\
\hline \multirow[t]{5}{*}{ July } & 5 & 5.1 & 960.0 \\
\hline & 10 & 4.8 & 964.0 \\
\hline & 17 & 5.6 & 970.4 \\
\hline & 24 & 5.6 & 976.0 \\
\hline & 31 & 2.5 & 978.5 \\
\hline August & 8 & 8.1 & 986.6 \\
\hline & 14 & 25.7 & $1,012.3$ \\
\hline & 21 & .5 & $1,012.8$ \\
\hline & 28 & .3 & $1,013.1$ \\
\hline
\end{tabular}

${ }^{1}$ Estimated rainfall.

when the crust was thin and little coolant water was used to several days when much coolant water was used in repeated drilling at one site through the thicker crust. Each probe, which consisted of a pointed mullite tube 1-inch $(2.54 \mathrm{~cm})$ in diameter with walls $0.25 \mathrm{~cm}$ thick, was pushed slowly under a load of about

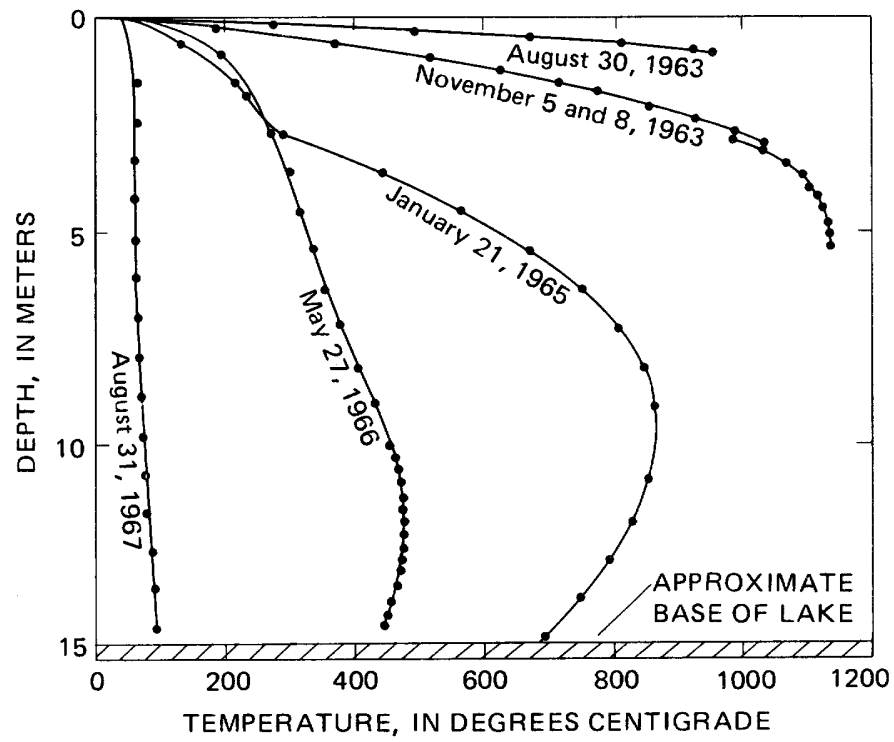

FiguRE 3-Representative temperature profiles in Alae lava lake.

200 pounds. The temperature and depth of the tip of the probe during its insertion on October 2, 1963 is shown as a function of time in figure 4 . On this date, as in each of the six attempts to emplace a probe in the melt, rapid penetration took place when the temperature at the tip of the probe was between $1,065^{\circ} \mathrm{C}$ and $1,070^{\circ} \mathrm{C}$. The best value for the temperature of insertion was $1,067^{\circ} \pm 2^{\circ} \mathrm{C}$, as reported earlier (Peck and others, 1964), but this value was later rounded to $1,065^{\circ} \mathrm{C}$ (Peck and others, 1966). The value, which represents the softening temperature of basaltic glass and crystals under the conditions of the experiment, is somewhat arbitrarily assigned as the temperature of the base of the crust. It is identical with the value determined in Kilauea Iki lava lake (Ault and others, 1962; Richter and Moore, 1966) and within the limits of error of the value of $1,070^{\circ} \mathrm{C}$ determined in Makaopuhi lava lake (Wright and others, 1968).

The rate at which the upper crust of Alae lava lake grew in thickness decreased rapidly from the beginning of solidification at the end of the eruption until a short time before complete solidification of the lake. The thickness of crust increased at the rate of about $0.14 \mathrm{~m}$ per day at the end of 1 day, $0.07 \mathrm{~m}$ per day at 10 days, $0.02 \mathrm{~m}$ per day at 100 days, and $0.015 \mathrm{~m}$ per day at 250 days. After 270 days the rate increased again at the main drilling site, reaching $0.06 \mathrm{~m}$ per day shortly before solidification was complete there at 300 days. The thickness of crust in the upper part of the lake at the main drilling site (DH1, 3, 4, 7, and 8), as determined from temperature profiles in the drill holes, is plotted against time in days after the eruption in figure 5 . The depths at which fluid lava was reached in drilling are also shown. As discussed above, these depths 


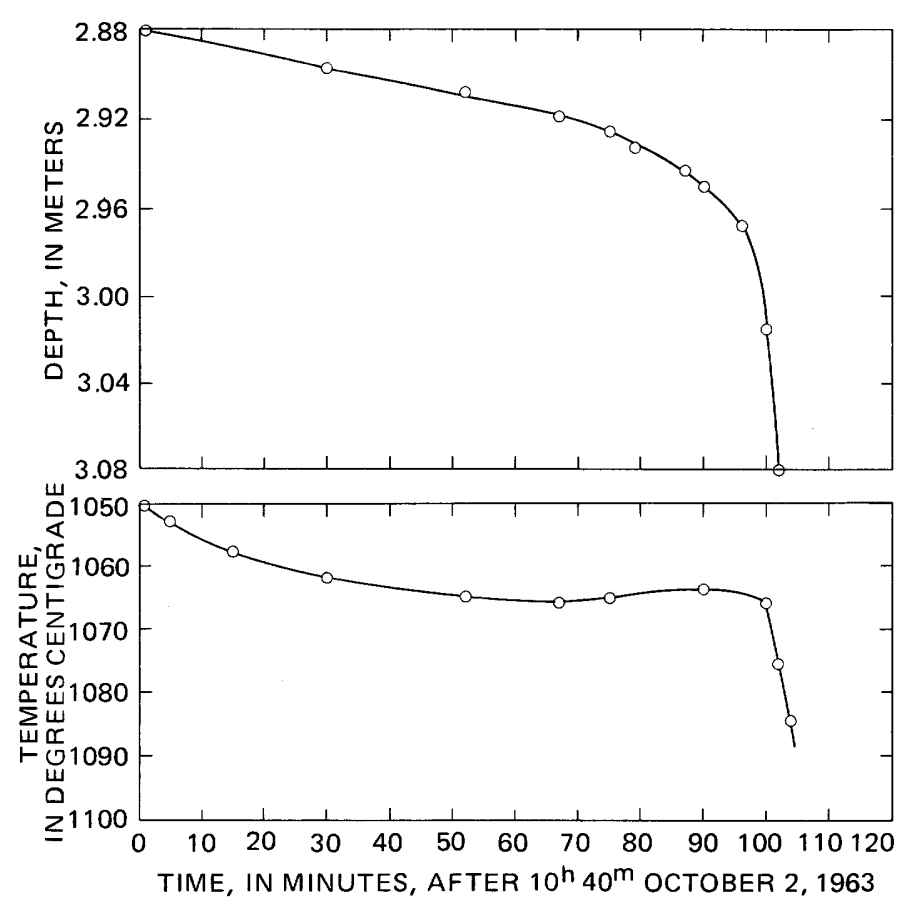

Figure 4.-Temperature and depth of the tip of a hollow mullite probe as a function of time during its insertion into fluid lava through the base of drill hole 3 on October 2, 1963, after drilling was completed at $10 \mathrm{~h} 40 \mathrm{~m}$.

were consistently greater than the depth of the $1,065^{\circ} \mathrm{C}$ isotherm. As shown in figure 5, the thickness of the crust as a function of time plots as a curved line having progressively decreasing slope during the first few months after the eruption. With respect to the square root of time, however, the thickness of the crust and the depth of isotherms in the crust and melt plot as straight line segments during the first 3 months, as discussed on page 13 .

Petrographic study of drill core from the lake shows that lava at a temperature of $1,065^{\circ} \mathrm{C}$ at the base of the crust contained 50 percent liquid (quenched to glass in the core) in a meshwork of crystals. At the inferred solidus temperature of $980^{\circ} \mathrm{C}$ and at lesser temperatures, the quenched lava contains a nearly constant 7 percent glass. At greater temperatures, the abundance of glass quenched from liquid increases smoothly to $1,070^{\circ} \mathrm{C}$, the highest temperature core recovered from the lake. At $1,140^{\circ} \mathrm{C}$, the projected maximum temperature in the lake, the lava contained about 13 percent crystals, as shown by the crystal content of pumice air quenched at this temperature during the final phases of the eruption, August 22 and 23, 1963. Temperatures across the zone of partly molten crust and the underlying fluid lava down to a temperature of $1,100^{\circ} \mathrm{C}$ on December 30,1963 , are shown in figure 6 , together with a curve showing the relative abundance of the melt fraction. This curve was derived by petrographic

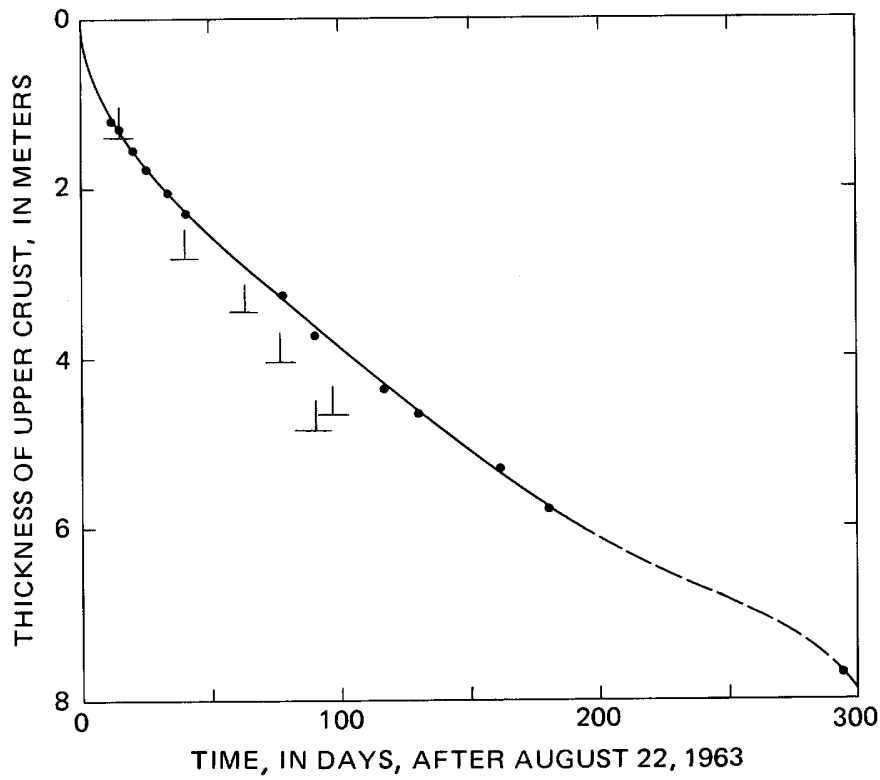

FIGURE 5.-Thickness of the upper crust of Alae lava lake near the main drilling site (DH 1, 3, 4, 7, and 8 ) as a function of time in days after August 22, 1963 (dots and curve). The depths at which fluid lava was reached in drilling are shown by vertical and horizontal bars.

study of core from several drill holes in Alae and in Makaopuhi lava lake (Wright and Peck, 1978; Wright and Okamura, 1977.) The temperature profile was measured in a ceramic tube emplaced in drill hole 4 through the crust and into underlying melt to a total depth of $5.5 \mathrm{~m}$ on December 2, 1963, 5 days after the hole was drilled through the crust. The profile shows the typical pronounced decrease in temperature gradient downward across the crust-fluid lava interface; this downward gradient was evident in each of the profiles measured across the zone on 11 separate days. Computer analysis of the thermal data (p. 43; Peck and others, 1976, fig. 6 ) indicates that the decrease can be attributed to the release of latent heat of crystallization within the zone rather than by a pronounced downward increase in thermal conductivity. The departure of the temperature profile from a smooth curve at a depth of about $4.7 \mathrm{~m}$ takes place at the horizon where the base of the crust was penetrated by drilling more than 1 month earlier; very likely this departure is an artifact of chilling by coolant water used in the drilling, as discussed in the following section.

The rate of crystallization with respect to change in temperature, measured by the decrease in the abundance of the melt fraction in samples quenched from different temperatures, was greater between $1,080^{\circ} \mathrm{C}$ and $1,050^{\circ} \mathrm{C}$ than at greater and lesser temperatures. The maximum crystallization rate was between $1,065^{\circ} \mathrm{C}$ and $1,060^{\circ} \mathrm{C}$, where the abundance of melt decreased nearly 8 percent. This relationship is shown by 


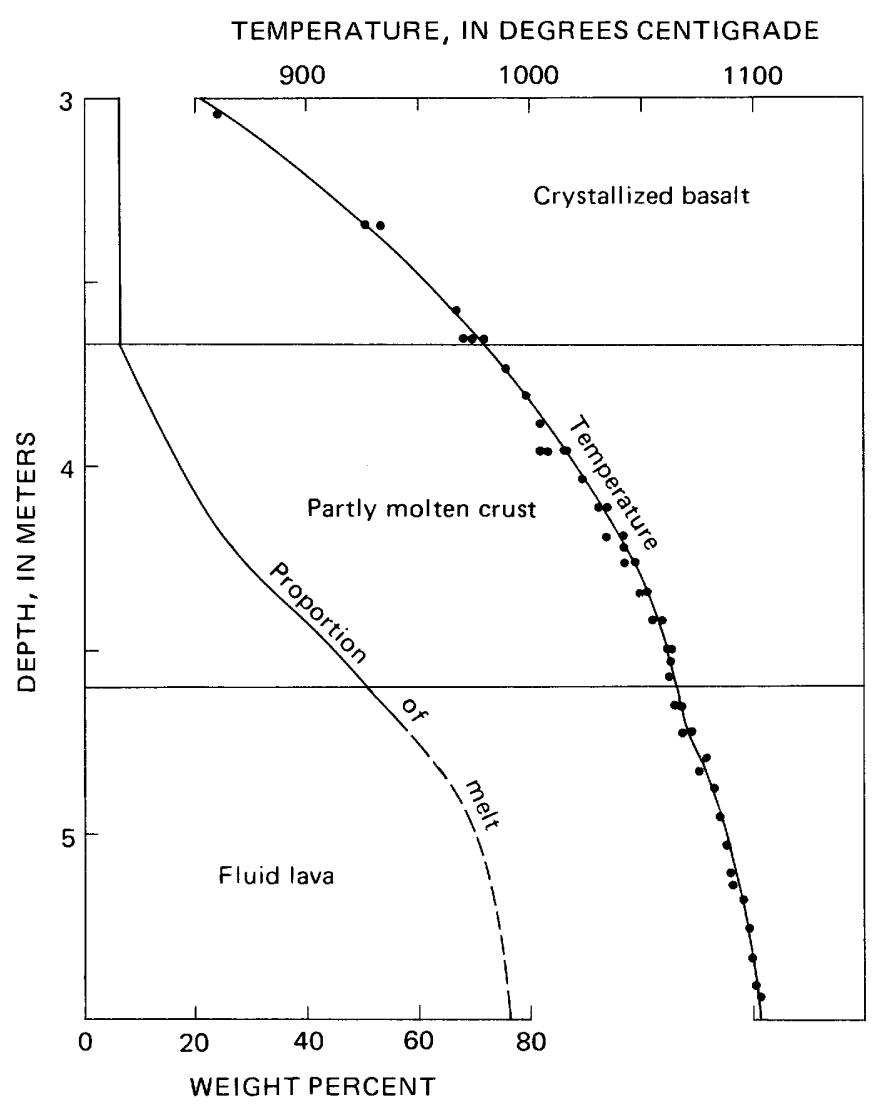

FiguRE 6.--Temperature profile across the zone of crystallization at the base of the crust on December 30,1963. Closed circles indicate measured temperatures. The inflection of the profile at $4.7 \mathrm{~m}$ is an artifact of coolant water used in drilling, as discussed in the text. Curve showing the relative abundance of the melt fraction was derived from study of core from several drill holes in Alae and Makaopuhi lava lakes (Wright and Peck, 1978).

study not only of drill core from Alae (Wright and Peck, 1978), but also of samples from a greater variety of temperatures from the 1965 Makaopuhi lava lake (Wright and others, 1968, fig. 12); the relationship differs from preliminary estimates of Peck, Wright, and Moore (1966, p. 11) which suggested a nearly linear relationship between the abundance of melt and temperature. During further cooling, from $1,065^{\circ} \mathrm{C}$ to $980^{\circ} \mathrm{C}$ within the zone of partly molten crust, the melt fraction continued to decrease in abundance and its composition became more silicic, as shown by the refractive index of glass quenched from melt; the analyzed composition of quenched melt that oozed into drill holes; and the analyzed composition of residual glass separated from drill core from the crust (Peck and others, 1966, fig. 5 and table 1; Wright and Peck, 1978). The silica content increases from 50.3 percent at $1,065^{\circ} \mathrm{C}$ to 75.8 percent at $980^{\circ} \mathrm{C}$.

Because of the marked decrease in the proportion of melt upward across the zone of partly molten crust, and to a lesser extent because of the decrease in melt tem- perature and increase in silica content, the viscosity of the lava increases sharply upward across the zone. Judging from the analysis of Shaw (1969, p. 519-520 and fig. 4), which was based on field measurements of viscosity in Makaopuhi lava lake (Shaw and others, 1968 ) as well as on laboratory measurements of viscosity of basaltic melts and silicone fluid-glass sphere suspensions, the limiting viscosity in Alae lava lake increased upward across the zone of crystallization from about $10^{7}$ at $1,065^{\circ} \mathrm{C}$ to $10^{18}$ at $980^{\circ} \mathrm{C}$.

\section{EFFECT OF COOLANT WATER ON TEMPERATURES}

As described in the section on "Drilling," the penetration of fluid lava below the crust was followed, after removal of the drill stem, by a jet of superheated steam. After each steam blast, temperature profiles in the bottom of the hole showed a reversal; temperatures increased with depth to a maximum near the position of the $1,065^{\circ}$ isotherm before drilling and then decreased with greater depth for $1 / 2-1 \mathrm{~m}$ to a minimum near the depth of penetration into the melt during drilling. Shortly after the penetration and steam blast of November 27, 1963, for example, the temperature was $975^{\circ} \mathrm{C}$ at a depth of $4.36 \mathrm{~m}$ but was only $700{ }^{\circ} \mathrm{C}$ at $4.66 \mathrm{~m}$. Temperatures in drill hole 3 , after drilling was completed at $12 \mathrm{~h} 20 \mathrm{~m}$ on November 7,1963 , are shown in figure 7 . The temperatures, which were measured at five different times during the 2-hour period of emplacement of a hollow probe into the melt, demonstrate the lower rate of thermal recovery with time near the base of the drill hole as compared with rates at more shallow depths. As shown in the figure, a minimum temperature was found at a depth of about $4.1 \mathrm{~m}$, just below the depth of penetration into fluid lava. The steam blasts and temperature reversals took place only after drilling into fluid lava. Apparently, both were caused by vaporized coolant water. When drilling within the crust, the steam escapes up the drill hole or laterally through joint cracks in the crust. The fluid lava, in contrast, traps the steam against the drill stem until the latter is withdrawn.

The temperature data from the lake discussed in the following sections were selected to avoid, as much as possible, the marked depression of isotherms caused by coolant water used in drilling. The effects of such water were marked after October 1 , when we began pumping coolant water through the drill pipe with a portable engine during drilling instead of pouring it into the hole by hand. Usually about 100 liters of water were used for each linear meter of drilling, but at times as much as 600 liters/meter were used. After repeated drilling at the main site in the southeast part of the lake during October and November 1963, temperatures were probably decreased in a considerable volume of crust beneath the site. After drilling, tempera- 


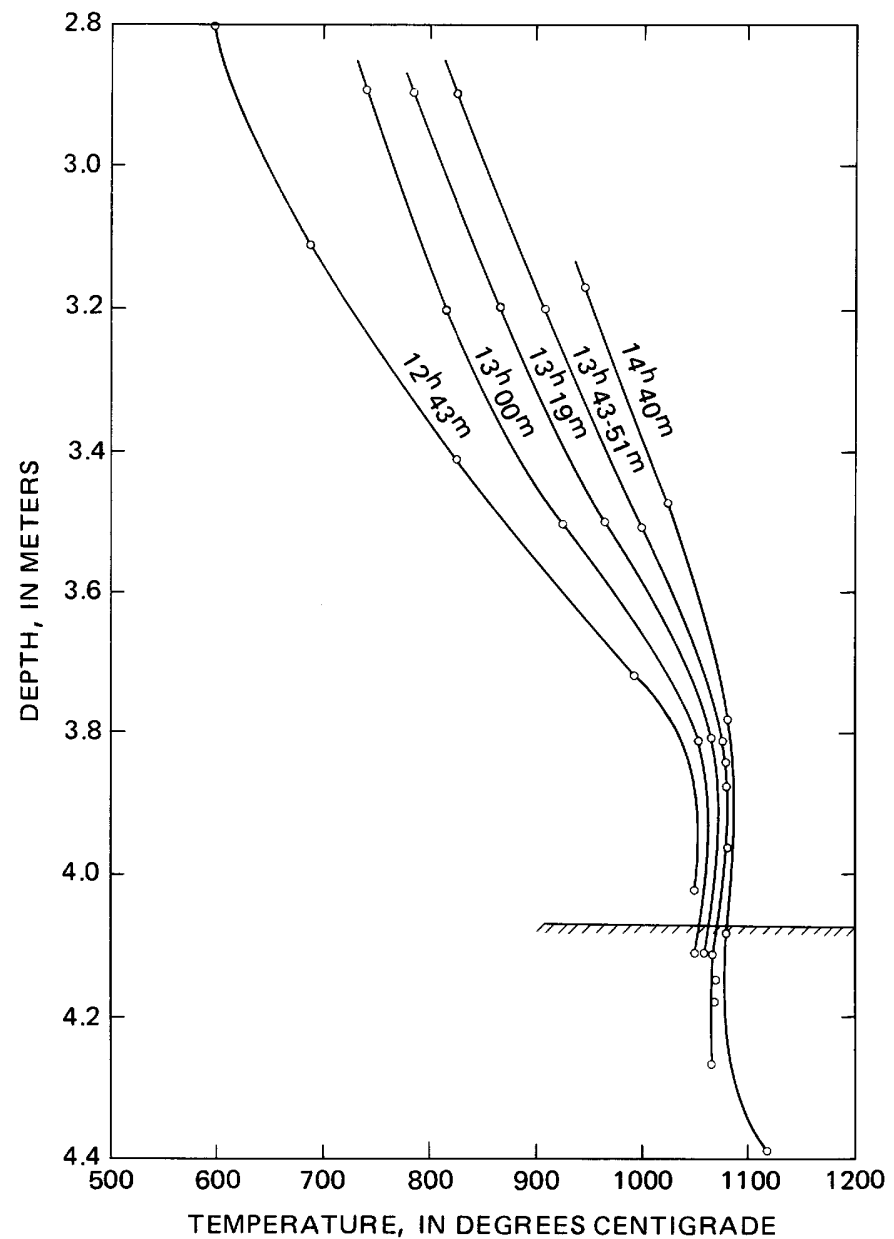

FIGURE 7.-Temperatures near the bottom of drill hole 3 after drilling through the base of the crust at $12 \mathrm{~h} 20 \mathrm{~m}$ November 7,1963 . Depth at which fluid lava was encountered during drilling is marked by hachured line at $4.068 \mathrm{~m}$.

tures in the lower part of the crust recovered to near predrilling levels within a few days, but those in the upper part required many weeks; temperatures at a depth of $30 \mathrm{~cm}$ were still rising 32 days after the drilling on November 27. Temperatures at a depth of 0.915 $\mathrm{m}$ in drill hole 3 were monitored continuously after the hole was deepened October 24, 1963, from 2.38-3.48 m using about 150 liters of coolant water. The continuous monitoring was part of a cooperative program with a visiting team of scientists and technicians from Japan, described on page 15 . The temperature at this depth, which was $570^{\circ} \mathrm{C}$ before drilling, climbed smoothly after drilling from $340^{\circ} \mathrm{C}$ at $23 \mathrm{~h}$ October 24 to $517^{\circ} \mathrm{C}$ at $03 \mathrm{~h}$ November 4 . The recovery of temperatures at different depths after drilling is shown in figure 8 , on which are plotted the depths of isotherms in the crust after drilling on November 27, 1963. Because only about 200 liters of water were used in the drilling on this date, the isotherms were not as strongly depressed

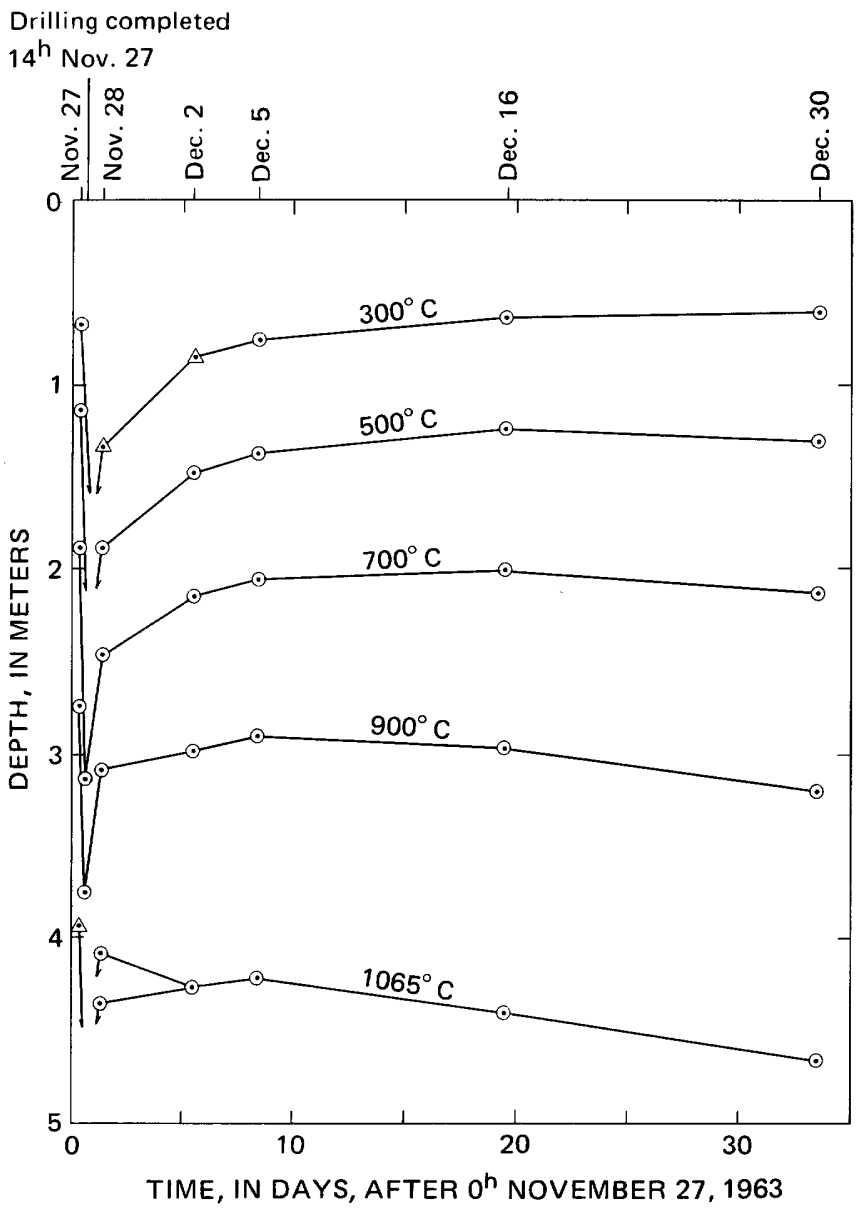

Figure 8.-Depth of isotherms in drill hole 4 before and after drilling on November 27, 1963. Circles represent measured temperatures. Triangles represent extrapolated temperatures.

as they were by other drilling operations. Increases in temperature with time were more closely monitored, however, because of repeated attempts to emplace a probe through the drill hole into molten lava and repeated measurements of temperatures in the probe once it was successfully emplaced. The figure shows the different relative depression and recovery rates of isotherms at different depths in the crust.

\section{TEMPERATURES IN FLUID LAVA BELOW THE CRUST}

Temperature profiles extending to $1,100^{\circ} \mathrm{C}$ or more-that is, to depths well below the base of the crust-were measured on October 24 , November 8 , and December 2, 3, 5, 18, and 30, 1963 (table 3). The longest profile in fluid lava was measured in a hollow ceramic probe on November 8, 1963 (fig. 9), 1 day after drilling into fluid lava at a depth of $4.08 \mathrm{~m}$. The maximum temperature measured was $1,135^{\circ} \mathrm{C}$ at a depth of 5.46 $\mathrm{m}$, an estimated $2 \mathrm{~m}$ above the depth of the maximum temperature in the lake. The very low temperature 


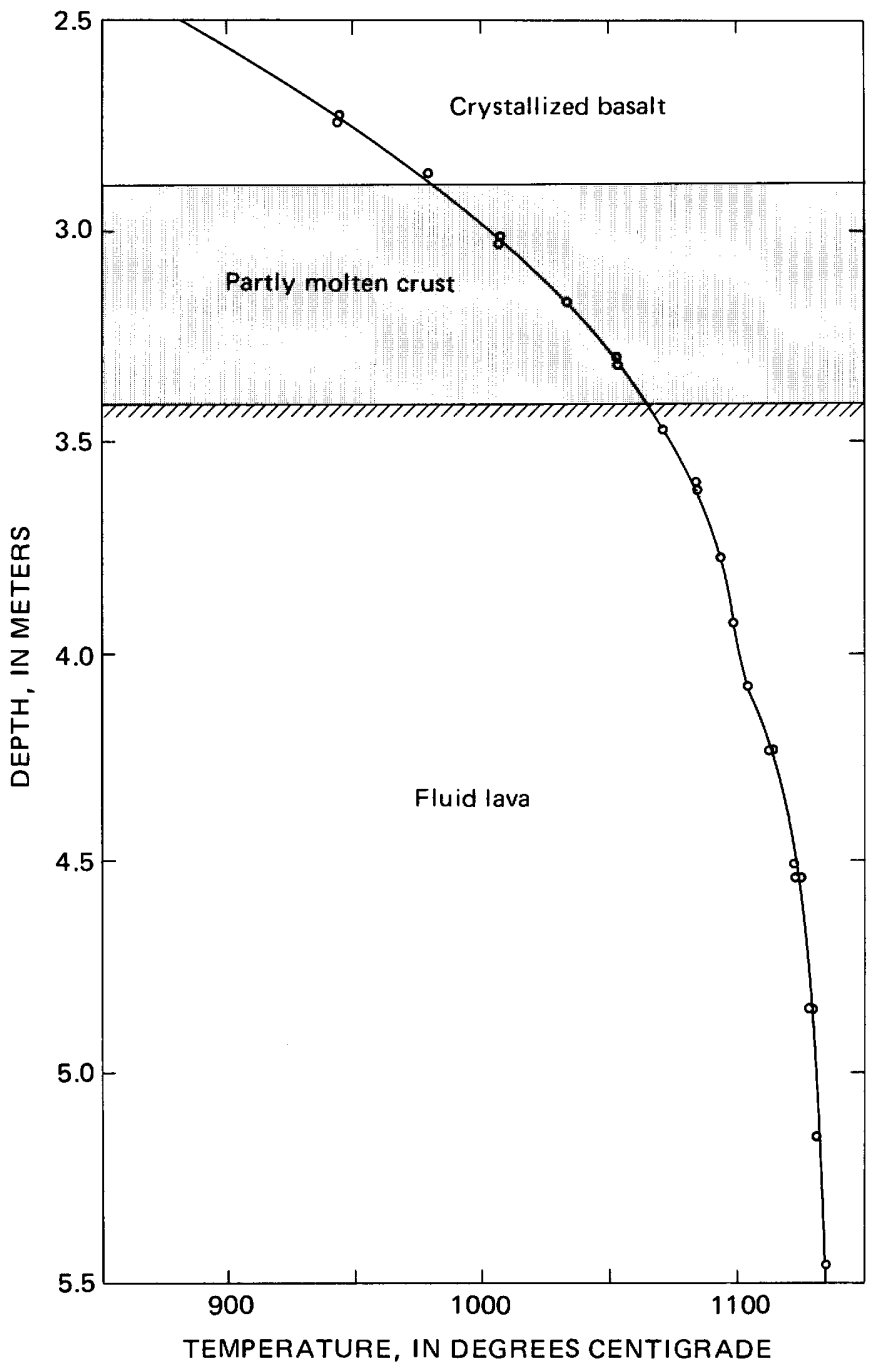

FigURE 9.-Temperature profile across partly molten crust and into underlying fluid lava on November 8, 1963. Open circles indicate measured temperatures. The zone of partly molten crust $\left(980^{\circ} \mathrm{C}\right.$ to $\left.1,065^{\circ} \mathrm{C}\right)$ is shaded and the base of the crust $\left(1,065^{\circ} \mathrm{C}\right)$ hachured.

gradient in the melt shown by the profile, only $8.5 \% \mathrm{~m}$ between $1,130^{\circ}$ and $1,135^{\circ} \mathrm{C}$, contrasts with the gradient of $240^{\circ} / \mathrm{m}$ measured in the crust between $710^{\circ} \mathrm{C}$ and $985^{\circ} \mathrm{C}$ before drilling on November 5 . As in the profile measured December 30, 1963 (fig. 6), the November 8 profile shows some residual effect from coolant water used in drilling; the profile departs from a smooth curve at the approximate depth $(4.1 \mathrm{~m})$ where the drill broke into fluid lava on November 7 .

\section{THERMAL HISTORY OF THE LAKE}

Temperatures in Alae lava lake during the 4 years when it solidified and cooled to less than $100^{\circ} \mathrm{C}$ are summarized in figure 10, in which the depths of isotherms in the lake, including the $1,065^{\circ} \mathrm{C}$ isotherm at the base of the crust, are plotted as a function of the square root of time after 06h August 22, 1963. The temperature profiles used in preparing the plot were selected to reduce to a minimum the effects of coolant water and are given and marked in table 3 . The solid lines (and short-dashed extrapolations) represent the depths of isotherms near the center of the lake in drill holes $1,3,4,7,8$, and 9 . The long-dashed lines represent the depths of isotherms as measured in drill hole 12 , the only deep drill hole that remained open and accessible to measurements during the final stages of cooling of the solidified lake. Temperatures at shallow depths in drill hole 12 are not representative of the lake as a whole, apparently because of heating of the lava enclosing the drill hole by gases rising through a fracture intersected by the hole. Also shown in the figure are the depths of the base of the lake at the main drilling site and at drill holes 9 and 12, and the cumulative rainfall at the south rim of Alae crater.

Contact temperatures at the lake surface were measured by means of mercury thermometers near the collars of drill holes on many days when temperatures were measured in the drill holes. The measured daytime surface temperature during the first 2 years of cooling of the lake over the central part of the lake ranged from $80^{\circ} \mathrm{C}$ to $30^{\circ} \mathrm{C}$ and averaged about $70^{\circ} \mathrm{C}$ during the first 5 months and about $40^{\circ} \mathrm{C}$ thereafter. Surface contact and radiation temperatures were measured systematically at $30-\mathrm{cm}$ intervals along a $31-\mathrm{m}$ base line near the center of the lake and at two "coldbase" stations at the thin margins of the lake in November and December 1964 when the maximum temperature in the lake was about $900^{\circ} \mathrm{C}$. Contact temperatures were measured by means of thermocouple, and infrared radiation temperatures $(>3$ micrometers wavelength) by means of a radiometer that views a conic section of $28^{\circ}$ and was held $30 \mathrm{~cm}$ above the ground. The results of the measurements and the calculated heat loss by radiation have been reported by Decker and Peck (1967). Radiation temperatures ranged from $15^{\circ} \mathrm{C}$ over the cooled margins of the lake at night to $85^{\circ} \mathrm{C}$ over fuming joint cracks near the center of the lake. The measurements show marked highs over fuming cracks and less marked highs over older cracks (Decker and Peck, 1967, fig. 3). During the day, radiation from most of the surface of the still hot center of the lava lake was not measurably different from the radiation from the sunlit basalt at the thin cooled margin of the lake. At night, however, radiation heat loss from internal sources over the central part of the lake was appreciable, constituting about 20 percent of the heat conducted to the surface.

The thickness of crust and the depth of isotherms in the crust and melt plot as nearly straight-line seg- 


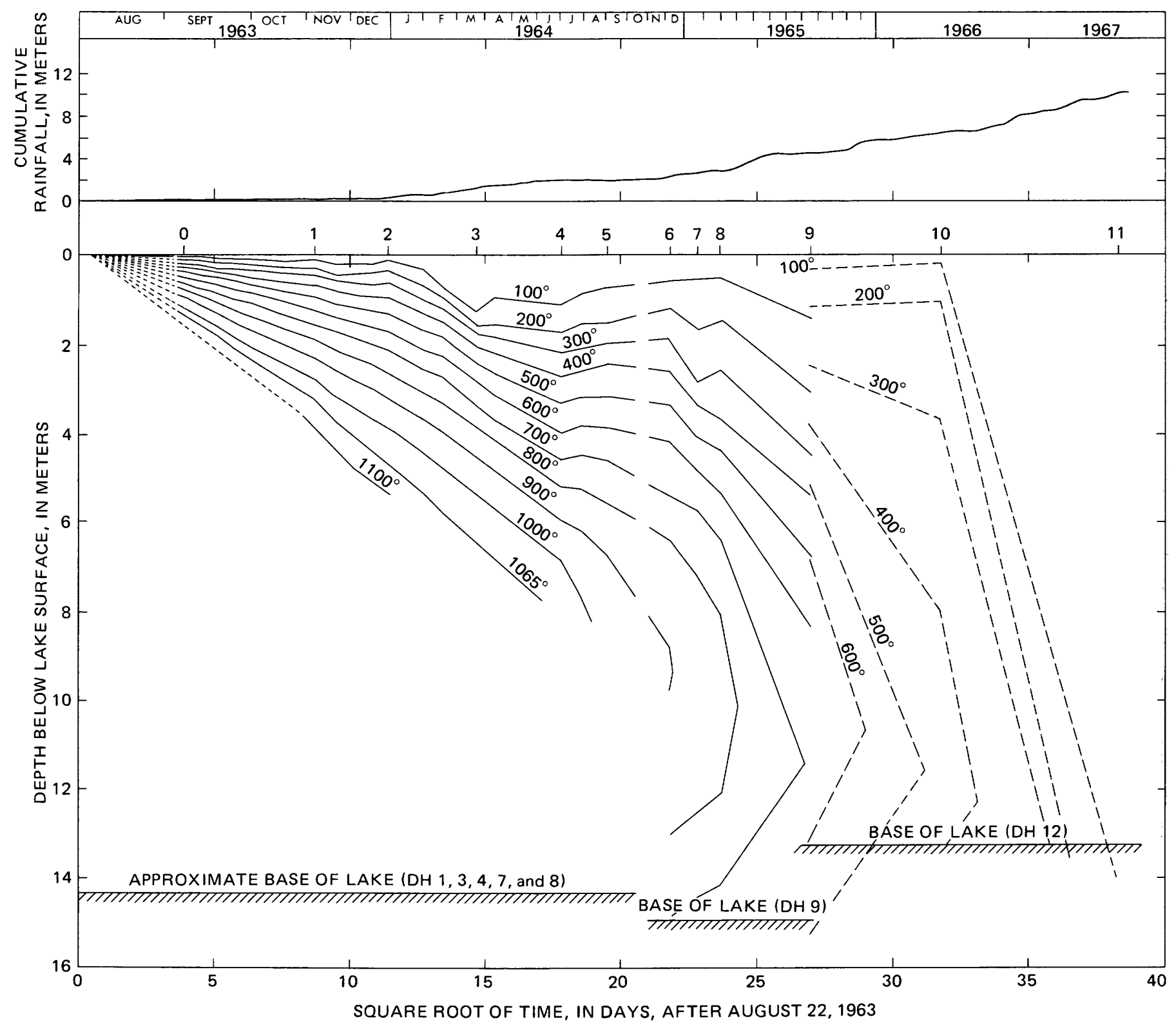

Figure 10.-Depth of isotherms (in degrees centigrade) in Alae lava lake from August 1963 to August 1967 as a function of the square root of time after $06 \mathrm{~h}$ August 22, 1963, and recorded rainfall at the south rim of Alae crater. Temperature measurements used in constructing the plot are marked in table 3. Rainfall is given in table 1, and the location of the drill holes plotted in figure 1 . Temperature profiles $(0-11)$ used in thermal modeling (see section on "Thermal Modeling") are marked above the zero depth line.

ments against the square root of time during the first 3 months. This relationship follows from heatconduction theory for the conductive cooling of a semiinfinite slab (Carslaw and Jaeger, 1959, p. 285), as discussed by Peck, Moore, and Kojima (1964, p. D4). The linear relationship is particularly well shown by temperature data collected during early and midSeptember, 1963 when rainfall was relatively sparse and little coolant water was used in the drilling. The depths of selected isotherms are shown in figure 11 for the first 25 days after the eruption as a function of the square root of time after 06h August 22, 1963. These depths lie on straight-line segments from September 3 to September 17. The excessive depths of the isotherms on August 30 were caused by coolant water used the previous day during the first drilling in the crust of the lake. Because of heavy rains on September 17, the depths of isotherms as measured 2 days later were de- 


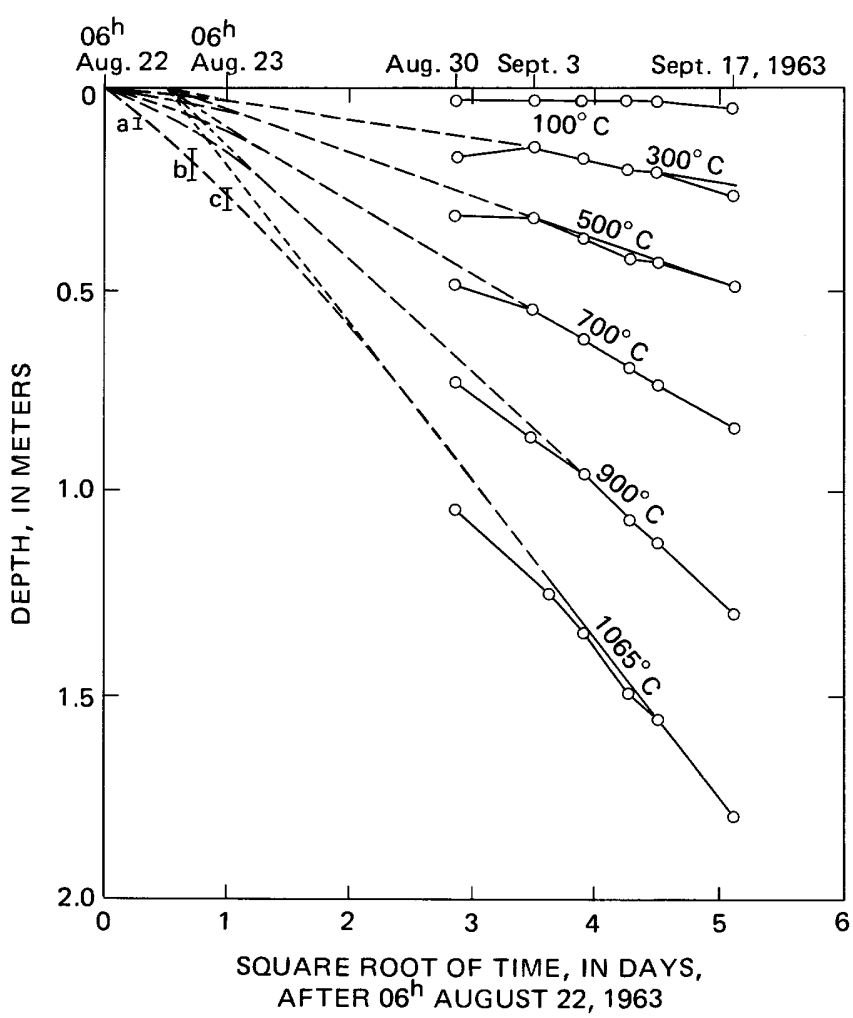

Figure 11.-Depth of isotherms (in degrees Centigrade) in Alae lava lake from August 22 to September 17, 1963, as a function of the square root of time in days after 06h August 22. Dashed lines are extrapolations of isotherms to zero depth on the basis of estimated thicknesses of crust during the August 1963 eruption on Alae crater and measured surface temperatures during the March 1965 eruption in Makaopuhi crater. Short-dashed lines are linear extrapolations of straight-line segments defined by the depth of measured temperatures from September 3 to 17 . Vertical bars a, b, and $c$ are thickness of crust estimated during the eruption, as discussed in the text.

pressed as much as $0.15 \mathrm{~m}$. During the following month and a half, the plotted depths continued to lie below the straight-line segments because of occasional heavy rains and the use of more abundant drilling water, but during periods of no rain or drilling, the depths tended to approach that of the straight-line segments.

The choice of zero time for the plot of figure 11 is arbitrary, because the exact time of formation of the crust varied from place to place on the lake. Some crust near the vent was not formed until drain back at the end of the eruption at $08 \mathrm{~h} 10 \mathrm{~m}$ August 23. Crust over linear ooze ups farther from the vent formed mostly during die-back of activity during the evening of August 22. Most of the crust over the central part of the lake probably formed by $06 \mathrm{~h}$, August 22 , when the rate of eruption dropped to nearly zero (Peck and Kinoshita, 1976). Estimates of the thickness of crust during the first several hours after its formation are also shown in figure 11. Thickness $a$ of $8-10 \mathrm{~cm}$ is based on the average thickness of pahoehoe slabs in the lava levee at the edge of the lake; the slabs are from crust that was rafted across the lake in about $1 \frac{1}{2}$ hours during the night of August 21-22. Thickness $b$ of $15-25 \mathrm{~cm}$ was estimated during a trip to the edge of the lava lake at $18 \mathrm{~h} 30 \mathrm{~m}$ on August 22; at that time the crust was barely thick enough to walk upon with caution. Thickness $c$ of $25-30 \mathrm{~cm}$ is based on the thickness of slabby crust in tumuli on the lake that were formed during drain back of molten lava into the vent after 06h, August 23. The depths of isotherms as measured in the drill holes are extrapolated backward in time as dashed lines to their inferred intersection with the zero depth axis on the basis of repeated optical pyrometer and thermometer measurements of surface temperatures during the March, 1965, eruption in Makaopuhi crater. Surface temperatures there dropped to 0.9 of the initial value after $10-20$ seconds, to $400^{\circ} \mathrm{C}$ after 30 minutes, to $200^{\circ} \mathrm{C}$ after 4 hours, and to $100^{\circ} \mathrm{C}$ after 1 day.

Linear projections backward in time of the segments established by the depths of isotherms in drill holes September 3-17 (dotted lines, fig. 11) do not intersect each other and the zero-depth axis unless an origin time of $12 \mathrm{~h}$ August 24, well after the end of the eruption, is selected. The intersection in figure 9 is at $\sqrt{ }$ days equals 0.55 , that is, $13 \mathrm{~h} 15 \mathrm{~m}$, August 22 . The exact time corresponding to the intersection has no real meaning; it reflects both the thermal constants and environment of the newly formed crust and also the somewhat arbitrarily chosen origin time. Intersection to the right of the origin, however, is significant. It records slower cooling of the crust and upper part of the melt with respect to the square root during the first few days. For the most part this probably was the result of the higher surface temperatures, but it may also have reflected a lower thermal diffusivity of the thin, highly vesicular crust as well as heating of the crust by gases exsolved from the underlying molten lava.

Temperatures near the base of the crust were monitored continuously at fixed positions in drill holes in the crust of the lake for several periods from midSeptember to mid-December 1963 . Temperatures were recorded as part of an investigation of possible variations in temperature arising from convection of molten lava in the lake and were carried out as a joint effort with a visiting team of scientists and technicians from Japan headed by Prof. T. Minakami. Millivolt differences were carried over wires to a millivolt chart recorder at the southeast rim of the crater from thermocouples fixed near the bottom of drill holes and from a thermistor in the vacuum bottle cold junction. Re- 
corded temperatures in the drill holes were checked periodically when temperature profiles were measured in the drill holes. From October 29 to November 5, 1963, for example, temperatures were recorded from a depth of $2.9 \mathrm{~m}$ in drill hole 3 , which was deepened on October 24 from $2.38 \mathrm{~m}$ to $3.48 \mathrm{~m}$, and the plotted temperatures were averaged over 1 hour periods. The temperature at this depth, which was initially within the zone of crystallization, fell smoothly during the monitoring period from $1,021^{\circ} \mathrm{C}$ to $958^{\circ} \mathrm{C}$. No systematic fluctuations were recorded that exceeded the precision of the thermocouple.

As shown in figure 10, the depths of isotherms deep in the crust and in the underlying fluid lava were nearly linear with respect to root time until early November 1963 and thereafter departed only slightly from linearity until the lake had solidified (cooled to less than $1,065^{\circ} \mathrm{C}$ ) in early July 1964 . Isotherms at shallow depths in the crust, however, departed markedly from linearity starting in early January 1964 largely as the result of rainfall. During the first 5 months of $1964,166 \mathrm{~cm}$ of rain were recorded at the south rim of the crater, in contrast to the $29 \mathrm{~cm}$ that fell during the preceding 4 months. Heating and vaporization of the rain water quenched a layer of crust immediately below the lake surface to steam temperature $\left(97^{\circ} \mathrm{C}\right.$ at the altitude of the lake), depressing the $100^{\circ} \mathrm{C}$ isotherm from $0.09 \mathrm{~m}$ to a depth of $1.22 \mathrm{~m}$ over the 5 months of abundant rainfall. After the rains ceased, the $100^{\circ} \mathrm{C}$ isotherm slowly decreased in depth as heat flowed into the surface layer from the underlying crust, but it was depressed again by abundant rainfall beginning in late February, 1965. Depression of the $200^{\circ} \mathrm{C}$ to $700^{\circ} \mathrm{C}$ isotherms by the early 1964 rains and their later partial recovery is also readily apparent in figure 10. As discussed in the section on "Thermal Modeling", measured temperatures can be closely matched by computed temperatures by withdrawing $620 \mathrm{calories}(540 \mathrm{cal} / \mathrm{g}$ heat of vaporization and $80 \mathrm{cal} / \mathrm{g}$ for heating from about $20^{\circ}$ to $100^{\circ} \mathrm{C}$ ) for each centimeter of measured rainfall. The effects of the heavy rains of January through May 1964 on the crust enclosing the upper part of drill hole 5 are shown in figure 12 . The hole was first drilled to a depth of $8.9 \mathrm{~m}$ through the partly molten center of the lake near its margin on December 16, 1963, and the central $1.07 \mathrm{~m}$ redrilled on January 29, 1964, to clear it of ooze. Thereafter no drilling took place in or near the hole. Figure 12 shows the progressive formation of a chilled layer near the surface and the later temperature recovery. At depths in the lava lake greater than about $2.5 \mathrm{~m}$ the cooling effect of rain water is less obvious.

Temperatures at a given depth varied significantly from one drill hole to another, even in the holes in the

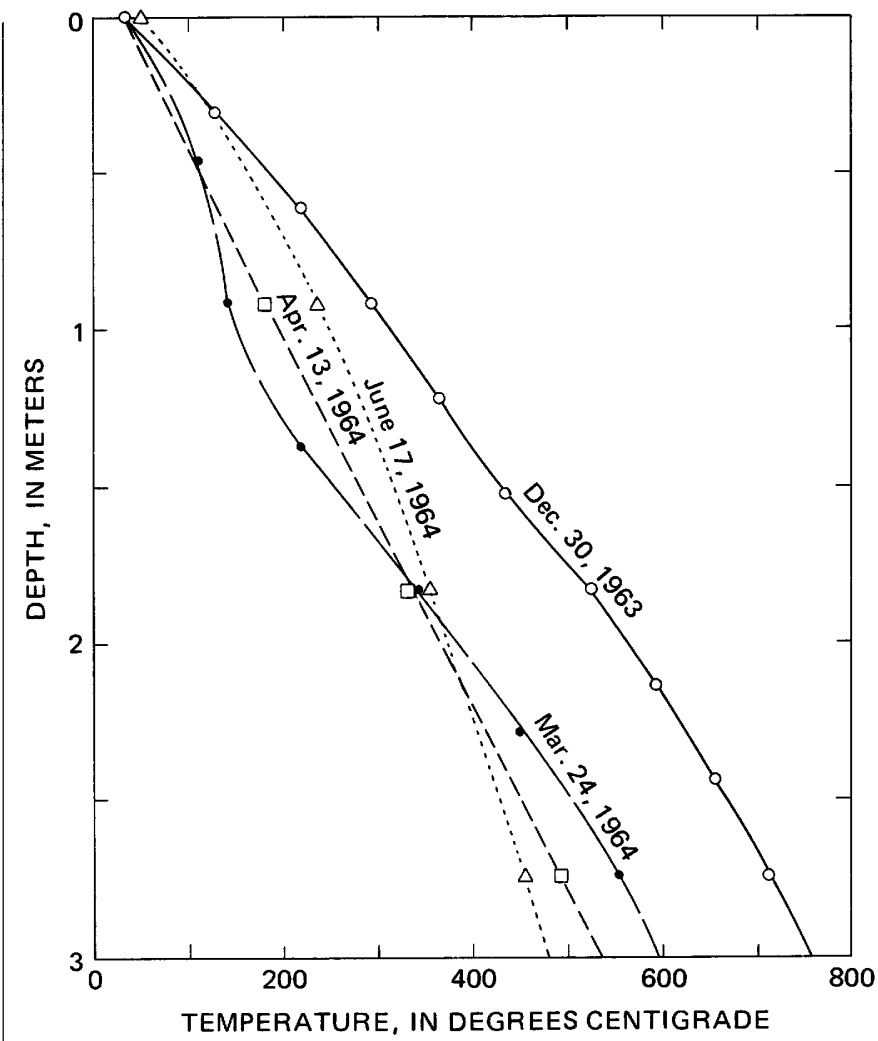

Figure 12.-Temperature profiles in the upper part of drill hole 5 near the southeast margin of Alae lava lake, showing the effects of abundant rainfall in the first 5 months of 1964 .

central part of the lake. During the first month after the eruption, measured temperatures in the upper 0.6 $\mathrm{m}$ of crust in drill holes 1 and 2 differed by $10-30^{\circ} \mathrm{C}$ (data for Sept. 9 and 11, 1963, table 3). During the second month, measured temperatures in the upper 1.6 $\mathrm{m}$ in drill holes 1 and 3 differed by $10-25^{\circ} \mathrm{C}$ (Oct. 24 and Nov. 5, 1963, table 3). Measured differences in temperature in different drill holes were greater during the second year of cooling, as illustrated in figure 13, which shows temperature profiles in five drill holes on January 21, 1965, 4 months after complete solidification of the lake. Also shown is a computed temperature profile for the same day, based on a numerical model for a lake 49 feet $(14.9 \mathrm{~m}$ ) thick (fig. 39). The coldest hole, drill hole 5 , was only about $30 \mathrm{~m}$ from the edge of the lake. Temperatures at a given depth within the upper $5 \mathrm{~m}$ of crust in three of the more centrally located holes (DH9, 10, and 11) varied within a range of $50^{\circ} \mathrm{C}-$ $100^{\circ} \mathrm{C}$. Temperatures in the other drill hole (DH12) were consistently $25-100^{\circ} \mathrm{C}$ greater than those in any other drill hole at depths of $8 \mathrm{~m}$ and less. At greater depths in drill hole 12 , temperatures were less than those in drill hole 9 because the lava lake was $1 \frac{1}{2} \mathrm{~m}$ shallower beneath the drill site. The differences in temperature reflect lateral variation in porosity (and conductivity) at shallow depths in the lake and cooling 


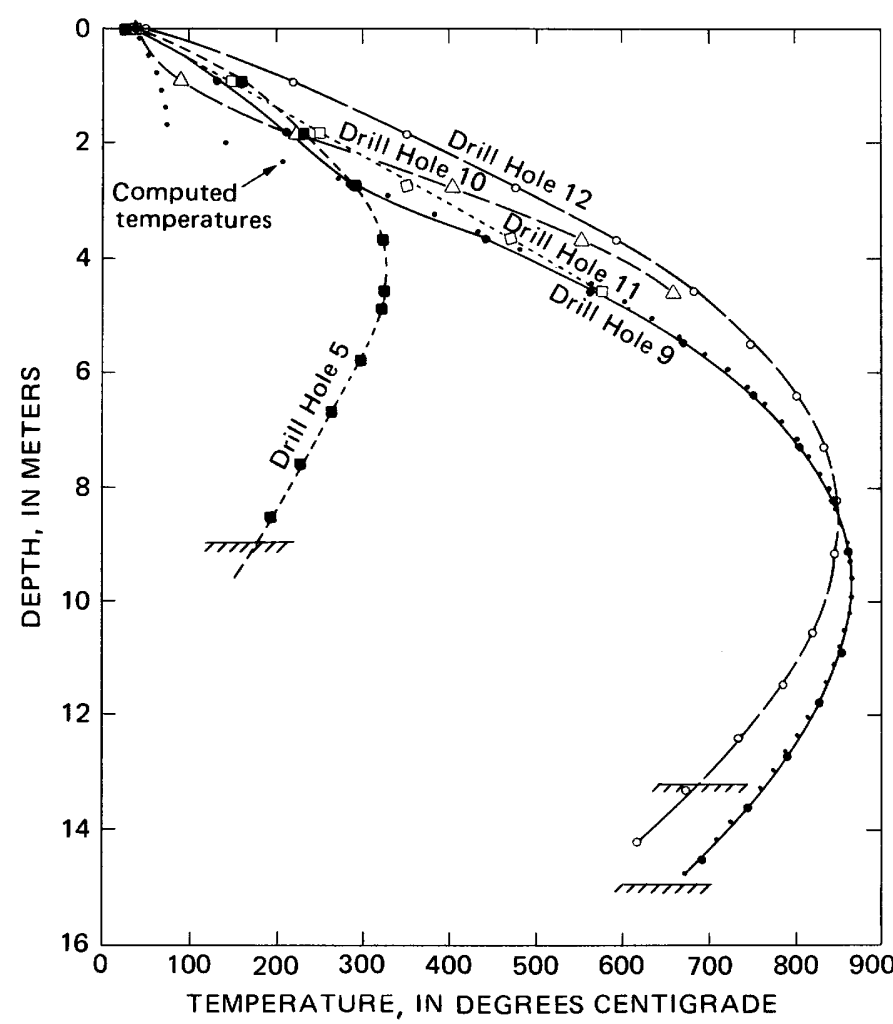

FIGURE 13.-Temperature profiles in five drill holes in Alae lava lake on January 21,1965 , and a computed profile for the same day based on a numerical model for a lake 49 feet $(14.9 \mathrm{~m})$ thick (fig. 39 ). Location of drill holes is shown in figure 1. Symbols indicate measured temperatures. Hachured lines beneath three of the profiles indicate the approximate depth of the base of the lake at these sites.

along joint cracks, although all holes were drilled as far as possible from known cracks. Lateral variations in vesicularity (porosity) in the lake were caused by differential entrapment of rising gases near the end of the eruption when the crust was 0.3-1.2 m thick (Peck and Minakami, 1968, p. 1154). Thermal conductivity decreases markedly with increased porosity as discussed on p. 41. Near the end of the eruption, the crust of Alae lava lake was broken by a network of cracks outlining polygonal slabs of crust 3-4.5 m across (Peck and Kinoshita, 1976); some of these cracks were drawn open during drain back at the end of the eruption, forming gaping crevasses as much as $30 \mathrm{~cm}$ wide which diverged outward from the central part of the lake. Seven days after the eruption, the temperature at a depth of $1.5 \mathrm{~m}$ in an open crack $12 \mathrm{~m}$ southeast of drill hole 1 was $885^{\circ} \mathrm{C}$. On this date, the base of the crust (at $1,065^{\circ} \mathrm{C}$ ) below drill hole 1 was at a depth of only $1 \mathrm{~m}$. Within a few weeks, the walls of these cracks cooled to less than red heat; by June 9, 1964, the temperature at a depth of $2 \mathrm{~m}$ in the crack southeast of drill hole 1 was only $35^{\circ} \mathrm{C}$. Lava adjacent to the cracks was cooled by air circulating in the cracks and by rainwater flowing into them. As a result, isothermal surfaces in the crust were strongly depressed near the cracks. As the crust of the lake cooled, cracks split to become deeper, and new cracks opened. Some of these provided channelways for hot gases that streamed upward from the molten and newly solidified basalt at depth in the lake and heated lava adjacent to the cracks. Drill hole 12 was split by such a crack; during drilling, water was turned to steam along the crack, making the drilling operation difficult. Rising gases along this crack caused temperatures at shallow depths in the drill hole to be greater than those in other holes.

\section{MAXIMUM TEMPERATURES AND TEMPERATURES AT THE BASAL CONTACT}

Maximum temperatures in the central part of Alae lava lake are estimated to have been $1,140^{\circ} \mathrm{C}$ on November 8,1963 , and $1,120^{\circ} \mathrm{C}$ on December 30,1963 , on the basis of $2 \mathrm{~m}$ extrapolations of temperature profiles measured in the crust and underlying fluid lava on those dates (figs. 6, 9). These values compare with maximum extrusion temperatures which fell from an estimated $1,160^{\circ} \mathrm{C}$ at the beginning of the eruption on August 21,1963 , to $1,140^{\circ} \mathrm{C}$ near the end of the eruption during the evening of August 22. Maximum temperatures in the lake were first measured beneath its thin margin on December 18, 1963, when a value of $1,066^{\circ} \mathrm{C}$ was recorded at a depth of $5.5 \mathrm{~m}$ in drill hole 5 (table 4). Maximum temperatures beneath the central part were first measured on July 2, 1964, 101/2 months after the eruption, when a value of $1,050^{\circ} \mathrm{C}$ was recorded at a depth of $8.2 \mathrm{~m}$ in drill hole 8 . Beneath the main drilling site on the central part of the lake, maximum temperatures in the lake fell steadily during the following 3 years, decreasing to $672^{\circ} \mathrm{C}$ on August 19,1965 , to $476^{\circ} \mathrm{C}$ on May 27, 1966. On August 31, 1967 , the maximum temperature measured was $90^{\circ} \mathrm{C}$ at the bottom of drill hole $12,1.1 \mathrm{~m}$ greater than the assumed depth of the base of the lake at that site. The measured values are very similar to values computed using numerical models, as discussed on p. 47.

Maximum temperatures in the lake beneath the main drilling site, (DH3, 4, 8, and 12), in the thin margin (DH5), and in the thickest part of the lake (DH9) are plotted in figure 14 as a function of the square root of time. The values beneath sites near the center of the lake plot as nearly linear curves at temperatures less than about $1,050^{\circ} \mathrm{C}$, facilitating the estimates of maximum temperatures on intermediate dates. Also indicated in figure 14 are maximum temperatures computed for a lake 49 feet $(14.9 \mathrm{~m})$ thick using the numerical model discussed in the section on "Thermal Modeling" and illustrated in figure 39. The computed temperatures agree closely with the measured values 
TABLE 4.-Depth and values of maximum temperatures and of basal contact temperatures in Alae lava lake

\begin{tabular}{|c|c|c|c|c|}
\hline Date & $\begin{array}{l}\text { Drill } \\
\text { hole }\end{array}$ & $\begin{array}{l}\text { Depth of maximum } \\
\text { temperature in } \\
\text { meters }(\text { most } \\
\text { values } \pm 0.15 \mathrm{~m})\end{array}$ & 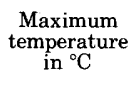 & $\begin{array}{c}\text { Basal contact } \\
\text { temperature in }{ }^{\circ} \mathrm{C}^{1} \\
\text { (values in paren- } \\
\text { theses are preferred) }\end{array}$ \\
\hline
\end{tabular}

1963

\begin{tabular}{|c|c|c|c|c|c|}
\hline $\begin{array}{l}\text { Nov. } \\
\text { Dec. }\end{array}$ & $\begin{array}{r}8 \\
18 \\
30 \\
30\end{array}$ & $\begin{array}{l}3 \\
5 \\
3 \\
5\end{array}$ & $\begin{array}{l}\text { estimated } \\
\text { estimated }\end{array}$ & $\begin{array}{l}7.5 \\
5.5 \\
7.5 \\
5.55\end{array}$ & $\begin{array}{r}\text { estimated } 1,140 \\
1,066 \\
\text { estimated } 1,120 \\
1,053\end{array}$ \\
\hline
\end{tabular}

\begin{tabular}{|c|c|c|c|c|c|}
\hline \multicolumn{6}{|c|}{1964} \\
\hline \multirow{3}{*}{$\begin{array}{l}\text { Jan. } \\
\text { Feb. }\end{array}$} & 29 & 5 & 5.6 & 960 & \\
\hline & 17 & 5 & 5.85 & 915 & \\
\hline & & 5 & 5.9 & 889 & \\
\hline \multirow{3}{*}{$\begin{array}{l}\text { March } \\
\text { April }\end{array}$} & 24 & 5 & 6.0 & 812 & \\
\hline & 3 & 6 & 7.5 & 1,060 & \\
\hline & 13 & 5 & 6.1 & 750 & \\
\hline \multirow[t]{2}{*}{ May } & 22 & 6 & 7.5 & 1,052 & \\
\hline & 27 & 5 & 5.7 & 636 & \\
\hline \multirow{4}{*}{$\begin{array}{l}\text { June } \\
\text { July }\end{array}$} & 17 & 5 & 5.8 & 580 & \\
\hline & 2 & 8 & 8.2 & 1,050 & \\
\hline & 2 & 5 & 5.5 & 552 & \\
\hline & 27 & 5 & 5.2 & 512 & \\
\hline \multirow{4}{*}{$\begin{array}{l}\text { Aug. } \\
\text { Sept. }\end{array}$} & 14 & 5 & 4.7 & 494 & \\
\hline & 3 & 5 & 4.4 & 476 & \\
\hline & 15 & 9 & 9.3 & 1,005 & \\
\hline & 21 & 5 & 4.6 & 455 & \\
\hline \multirow{3}{*}{ Oct. } & 21 & 9 & 9.1 & 995 & \\
\hline & 16 & 5 & 4.0 & 440 & \\
\hline & 16 & 9 & 9.3 & 950 & \\
\hline \multirow[t]{3}{*}{ Dec. } & 8 & 5 & 4.0 & 392 & \\
\hline & 8 & 9 & 9.3 & 902 & $725 \pm 50$ \\
\hline & 8 & 12 & 8.5 & 872 & $\begin{array}{c}690 \pm 30 \\
(710)\end{array}$ \\
\hline
\end{tabular}

\begin{tabular}{|c|c|c|c|c|c|}
\hline \multicolumn{6}{|c|}{1965} \\
\hline Jan. & $\begin{array}{l}21 \\
21\end{array}$ & $\begin{array}{l}5 \\
9\end{array}$ & $\begin{array}{l}4.3 \\
9.75\end{array}$ & $\begin{array}{l}328 \\
865\end{array}$ & $\begin{array}{c}695 \pm 45 \\
(670)\end{array}$ \\
\hline & 21 & 12 & 8.5 & 850 & $\begin{array}{c}645 \pm 45 \\
(675)\end{array}$ \\
\hline March & $\begin{array}{l}2 \\
2\end{array}$ & $\begin{array}{l}5 \\
9\end{array}$ & $\begin{array}{l}4.3 \\
9.9\end{array}$ & $\begin{array}{l}285 \\
833\end{array}$ & $\begin{array}{c}685 \pm 50 \\
(655)\end{array}$ \\
\hline & 2 & 12 & 8.7 & 817 & $\begin{array}{c}630 \pm 40 \\
(660)\end{array}$ \\
\hline July & $\begin{array}{l}6 \\
6\end{array}$ & $\begin{array}{l}5 \\
9\end{array}$ & $\begin{array}{r}4.9 \\
11.0\end{array}$ & $\begin{array}{r}95 \\
725\end{array}$ & $\begin{array}{c}640 \pm 30 \\
(615)\end{array}$ \\
\hline & 6 & 12 & 9.75 & 720 & $\begin{array}{c}585 \pm 30 \\
(610)\end{array}$ \\
\hline Aug. & $\begin{array}{l}19 \\
19\end{array}$ & $\begin{array}{l}5 \\
9\end{array}$ & $\begin{array}{r}4.9 \\
11.6\end{array}$ & $\begin{array}{r}95 \\
688\end{array}$ & $\begin{array}{c}620 \pm 30 \\
(600)\end{array}$ \\
\hline & 19 & 12 & 9.75 & 672 & $\begin{array}{c}570 \pm 30 \\
(595)\end{array}$ \\
\hline \multicolumn{6}{|c|}{1966} \\
\hline May & 27 & 12 & 11.9 & 476 & $\begin{array}{c}460 \pm 10 \\
(465)\end{array}$ \\
\hline \multicolumn{6}{|c|}{1967} \\
\hline Aug. & 31 & 12 & 13.1 & $88 \pm 2^{2}$ & $\begin{array}{c}88 \pm 2 \\
(86)\end{array}$ \\
\hline
\end{tabular}

in DH9. The values for drill hole 5 plot more erratically than those for other drill holes, at least in part because of the effect of abundant rainfall on the relatively cool margin of the lake after the heavy rains in early 1964 and early 1965 .

The depth of the maximum temperature beneath the central part of the lake (table 4) fell systematically with time as the temperature decreased. Ranges of values for the proportionate depth (the ratio of depth of the maximum temperature to the thickness of the lake) in several drill holes are plotted as a function of the maximum temperature in figure 15. A large range of values for the proportionate depth for each hole is indicated in the figure because of uncertainties in the depth of the basal contact. This uncertainty for drill holes 9 and 12 can be greatly reduced if we can assume that the proportionate depth of the maximum temperature was the same in each hole on any given day. On this basis, the lake thickness was $14.9 \pm 0.1 \mathrm{~m}$ at DH9 and $13.3 \pm 0.2$ at $\mathrm{DH} 12$. The same values are obtained from similar assumptions as to the values of the contact temperatures. The smooth curve in figure 15 was constructed using these values for lake thickness and shows a decrease in the proportionate depth from about 0.6 when the maximum temperature was $1,050^{\circ}-$ $1,000^{\circ} \mathrm{C}$, to 0.75 at $680^{\circ}, 0.9$ at $475^{\circ}$, and 1.1 or more (below the lake) at $90^{\circ}$. Computed proportionate depths are also shown, based on the model illustrated in figure 39.

Contact temperatures at the base of the central part of the lake were first measured on December 8, 1964 and are given in table 4 . Large ranges of values are indicated because of uncertainties in the exact depth of the basal contact in each hole, but the ranges for drill holes 9 and 12 can be reduced by the assumptions discussed above. On this basis, contact temperatures were as much as $700 \pm 10^{\circ} \mathrm{C}$ (60 percent of the beginning temperature of the lake) when first measured on December 8,1964 , and decreased slowly to $600^{\circ} \pm 10^{\circ} \mathrm{C}$ on August 19, 1965. Computed contact temperatures at the base of a lake 49 feet $(14.9 \mathrm{~m})$ thick with a latent heat of $80 \mathrm{cal} / \mathrm{g}$ fell from $668^{\circ} \mathrm{C}$ to $606^{\circ} \mathrm{C}$ for the same period. From May 27, 1966, to August 31, 1967, the measured contact temperatures fell from $465^{\circ} \mathrm{C}$ to $86^{\circ} \mathrm{C}$.

Footnotes to table 4 .

${ }^{1}$ Depth of basal contact estimated to be $9 \pm 1 \mathrm{~m}$ in DH5; $13 \pm 1 \mathrm{~m}$ in DH6, and $14 \pm 1 \mathrm{~m}$ in DH8, based on vertical angle and level surveys after formation of the lake (table 6 ) and preeruption topography of Alae crater determined photogrammetrically (fig. 1). Depth of basal contact in DH9 determined to be $14.5 \pm 0.8 \mathrm{~m}$, on the basis of the recovery of drill core of 1840 lava between 14.6 and $15.2 \mathrm{~m}$. Depth of basal contact in DH12 estimated to be $13.7 \pm 0.6$ $\mathrm{m}$ on the basis of a cavernous layer penetrated in drilling between 13.1 and $14.3 \mathrm{~m}$. If the assumption is valid that basal contact temperatures beneath drill holes 9 and 12 and the proportionate depths of the maximum temperature were the same on a given day, the depths of the basal contact are $14.9 \pm 0.1 \mathrm{~m}$ at $\mathrm{DH} 9$ and $13.3 \pm 0.2 \mathrm{~m}$ at $\mathrm{DH} 12$. Contact below the assumed depth of the base of the lake. 


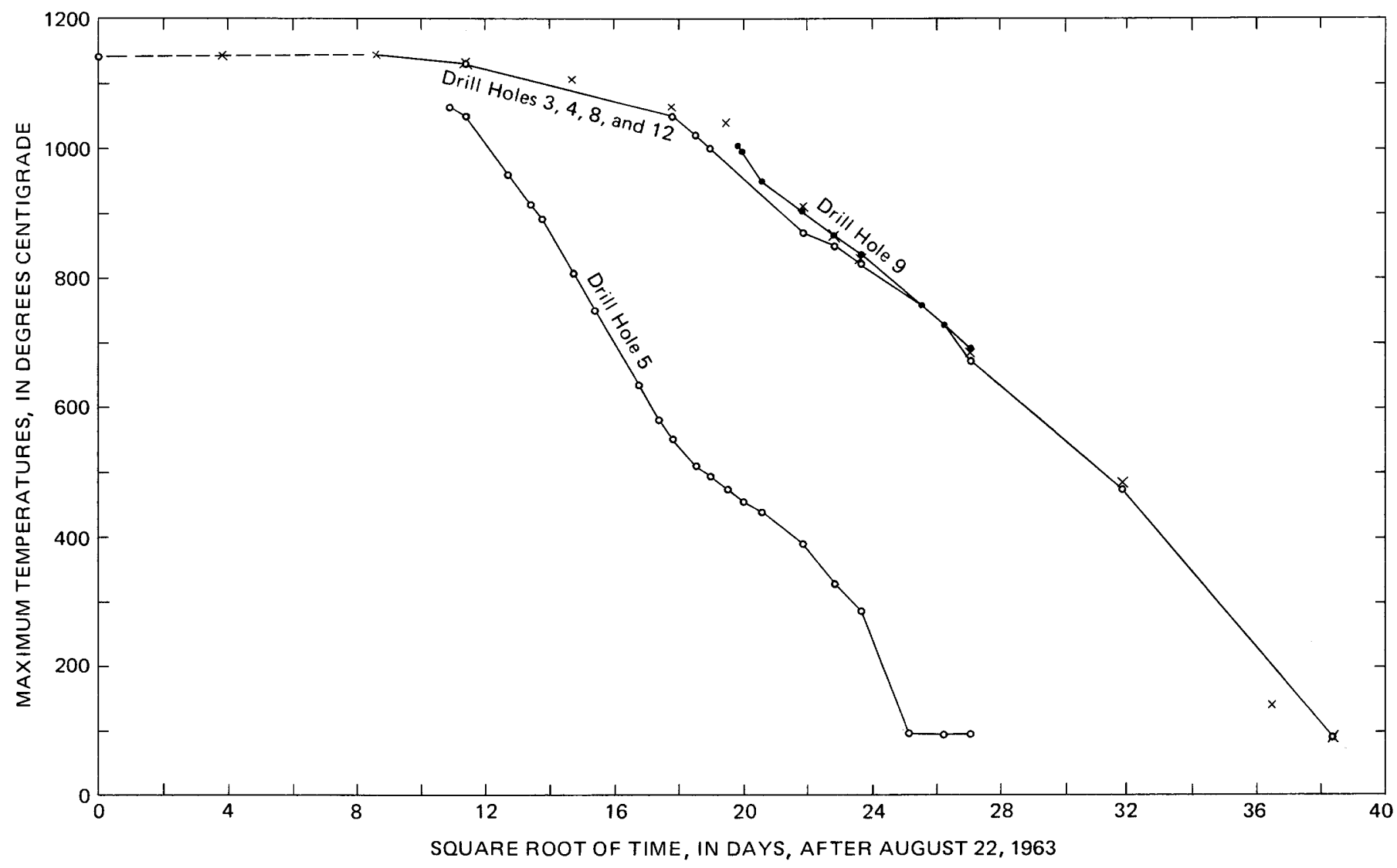

FIGURE 14.-Maximum temperatures at three sites in Alae lava lake as a function of the square root of time in days. Location of drill holes shown in figure 1. Crosses indicate computed temperatures derived from figure 39; black circles indicate measured temperatures in drill hole 9; open circles indicate measured temperatures in other drill holes.

\section{DENSITY OF ALAE LAVA AND VARIATION WITH TIME OF THE ALTITUDE OF THE LAKE SURFACE}

Molten basalt in Alae lava lake vesiculated because of the exsolution of gases as the lava cooled and solidified. The rate of vesiculation with time was recorded in the abundance of vesicles in solidified basalt newly added to the crust of the lake. The variation of vesiculation with temperature can be deduced from the size and shape of vesicles and the petrography of quenched partly molten basalt in drill core from near the base of the crust. Because of vesiculation, fluid lava in the lake expanded as it solidified, causing the surface of the lake to extend horizontally and to rise vertically. The solidified margin, in contrast, subsided because of thermal contraction. As a result, we were able to determine the outline of the lens of fluid and partly molten lava and record its shrinkage with time by means of repeated surveys of the altitude of stations on the lake surface as well as the measurement of temperatures in drill holes. Data from the surveys and other measurements are used to calculate the density of fluid lava in the lake early in its cooling history. Repeated surveys of the stations after solidification of the lake reveal the pattern of continued cooling and provide data that are used to calculate the bulk coefficient of thermal expansion. This section presents data on the density and vesicularity of the lava and on the changing altitude of the lake surface; the integration of this data and temperature data provides an analysis of the altitude changes.

\section{DENSITY AND VESICULARITY}

The measured density of individual pieces of drill core of solidified basalt from the lake ranges from 1.66 to $2.78 \mathrm{~g} / \mathrm{cc}$. In general density increased downward in the lake from an average value of $1.80 \mathrm{~g} / \mathrm{cc}$ within 10 $\mathrm{cm}$ of the upper surface to a nearly constant 2.67 to $2.68 \mathrm{~g} / \mathrm{cc}$ at depths below $3 \mathrm{~m}$. Average values of density at $0.3-\mathrm{m}$ intervals from the surface to a depth of 3 $\mathrm{m}$ and at $1 \frac{1 / 2}{2} \mathrm{~m}$-intervals below that are given in table 5 and plotted in figure 16. Density was determined by planing flat the ends of each core $1 \mathrm{~cm}$ or more in length from the 12 drill holes and measuring its volume and weight. A total length of $429 \mathrm{~cm}$ of core was measured (almost all $1.43 \mathrm{~cm}$ diam), an average of 


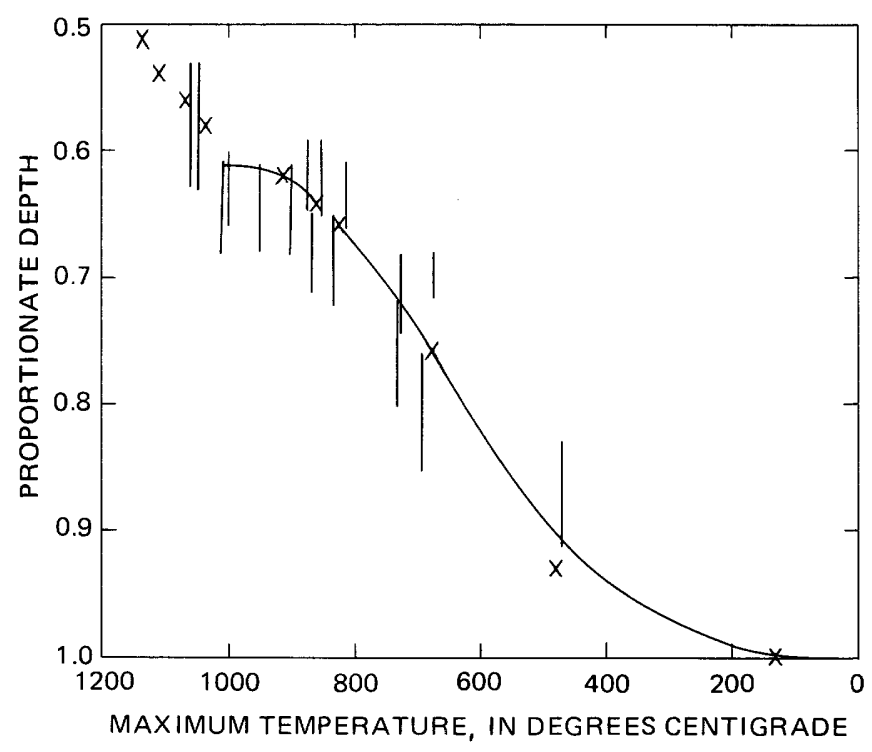

FIGURE 15.-Proportionate depth of the maximum temperature in four drill holes in the central part of the lake as a function of the value of the maximum temperature. The smooth curve was constructed on the assumption that the proportionate depths of the maximum temperatures in DH9 and 12 and values of the basal contact temperatures were the same in each drill hole. Crosses indicate computed depths and temperatures based on the thermal model illustrated in figure 39 .

about 30 percent for each interval. Because only a few drill holes penetrated the lower half of the lake, only a small amount of core was recovered below $6 \mathrm{~m}$. Core recovery also was poor from the more vesicular zones in the lake, particularly from the highly vesicular and cavernous layer at a depth between 0.3 and $0.6 \mathrm{~m}$. The density values listed in table 5 and plotted in figure 16 are probably biased towards greater density, particularly for depths less than $5 \mathrm{~m}$.

TABLE 5.-Bulk density and porosity of drill core [All values are for core collected from temperatures less than $1,000^{\circ} \mathrm{C}$ ]

\begin{tabular}{rrrrc}
$\begin{array}{c}\text { Depth } \\
\text { interval }(\mathrm{m})\end{array}$ & $\begin{array}{c}\text { Total length } \\
\text { of core }(\mathrm{cm})\end{array}$ & $\begin{array}{c}\text { Average } \\
\text { density } \\
\text { (g/cc) }\end{array}$ & $\begin{array}{c}\text { Range in } \\
\text { measured } \\
\text { density } \\
\text { (g/cc) }\end{array}$ & $\begin{array}{c}\text { Calculated }^{2} \\
\text { porosity } \\
\text { (in percent) }\end{array}$ \\
\hline $0-0.3$ & 123 & 1.91 & $1.66-2.43$ & 37 \\
$0.3-0.6$ & 7 & 2.12 & $1.86-2.43$ & 30 \\
$0.6-0.9$ & 17 & 2.22 & $1.75-2.47$ & 26 \\
$0.9-1.2$ & 17 & 2.36 & $1.91-2.64$ & 22 \\
$1.2-1.5$ & 14 & 2.34 & $1.91-2.64$ & 22 \\
$1.5-1.8$ & 17 & 2.47 & $2.13-2.56$ & 18 \\
$1.8-2.1$ & 25 & 2.50 & $2.19-2.60$ & 17 \\
$2.1-2.4$ & 16 & 2.43 & $2.19-2.65$ & 19 \\
$2.4-2.7$ & 30 & 2.59 & $2.37-2.71$ & 14 \\
$2.7-3.0$ & 13 & 2.61 & $2.52-2.71$ & 13 \\
$3.0-4.5$ & 51 & 2.68 & $2.54-2.78$ & 11 \\
$4.5-6.0$ & 29 & 2.67 & $2.60-2.70$ & 11 \\
$6.0-7.5$ & 20 & 2.65 & $2.61-2.65$ & 12 \\
$7.5-9.0$ & 7 & 2.68 & $2.61-2.70$ & 11 \\
$9.0-10.5$ & 14 & 2.68 & $2.65-2.70$ & 11 \\
$10.5-12.0$ & 15 & 2.67 & $2.63-2.75$ & 11 \\
$12.0-13.5$ & 14 & 2.66 & $2.63-2.72$ & 12 \\
\hline-
\end{tabular}

${ }^{1}$ Weighted by length of each piece of core.

${ }^{2}$ Porosity calculated using the average measured grain density of $3.01 \mathrm{~g} / \mathrm{cc}$.

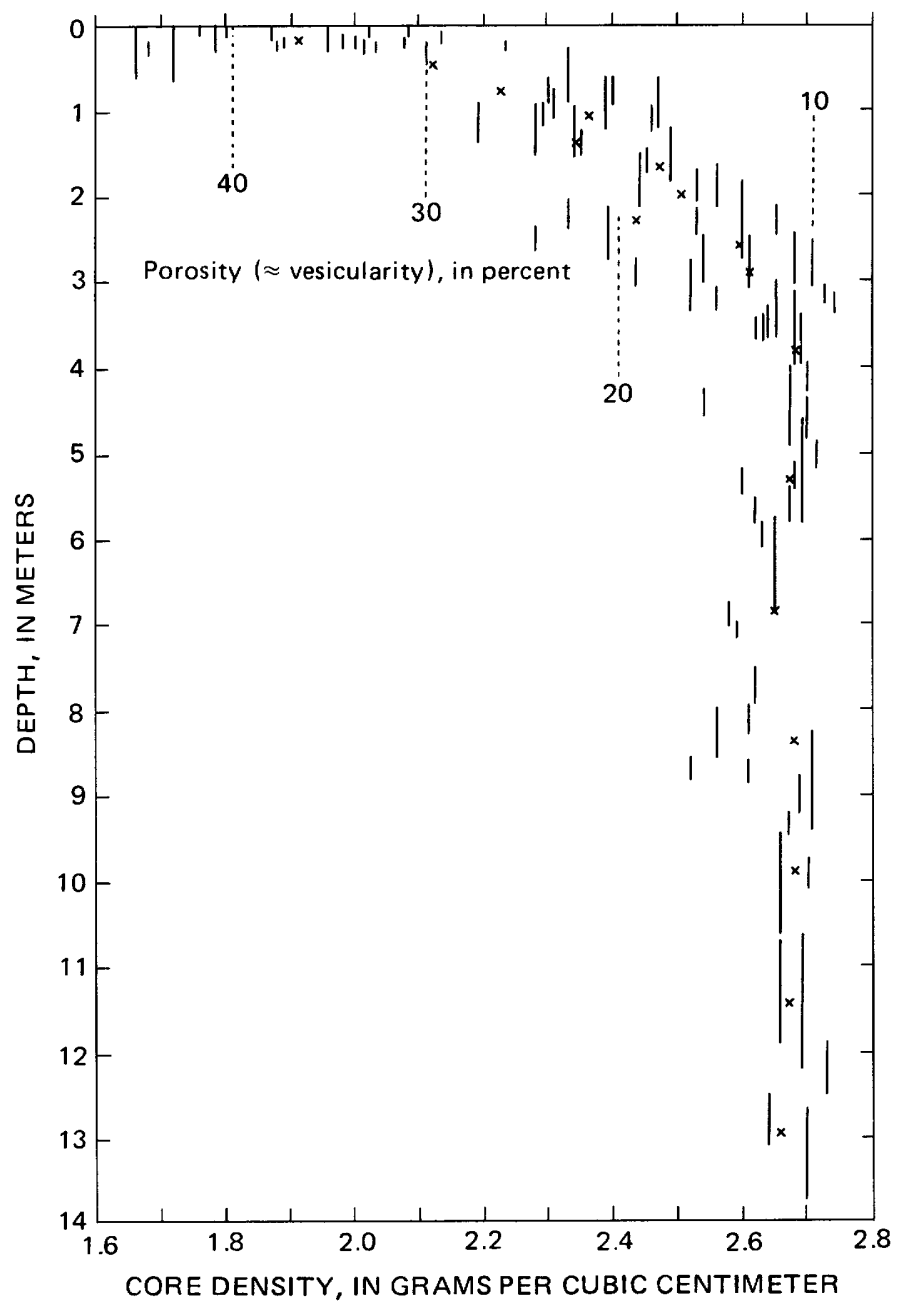

FIGURE 16.-Average core density and porosity (approximately equal to vesicularity) as a function of depth. Vertical bars indicate density of individual pieces of core from the indicated interval. X's show average values for $0.3-\mathrm{m}$ intervals from 0 to $3 \mathrm{~m}$ and $1 \frac{112 \mathrm{~m}}{2}$ intervals below.

Density increased with depth in the lake because of a decrease in the abundance of vesicles. Because of the nearly constant mineralogic composition of the Alae basalt, the porosity, $\phi$, in percent, can be calculated from the bulk density, $\rho_{b}$, and the average grain density, $\rho_{\mathrm{g}}$, using the following equation (Daly and others, 1966, p. 21):

$$
\phi=100\left(1-\frac{\rho_{b}}{\rho_{g}}\right)
$$

The grain densities of eight samples of basalt from the lake range from 2.92 to $3.04 \mathrm{~g} / \mathrm{cc}$ and average $3.01 \mathrm{~g} / \mathrm{cc}$. Porosity of the basalt is nearly equivalent to the vesicularity. A small proportion of the porosity of all the samples, however, probably is caused by microfractures that formed as the result of thermal stresses induced by cooling. The microfracture porosity is 
suggested by analysis of laboratory measurements of thermal conductivity of Alae and other Hawaiian basalt samples (Robertson and Peck, 1974) and by comparison of the coefficient of thermal expansion calculated from temperature and leveling data from Alae with values measured in the laboratory (Skinner, 1966; Richter and Simmons, 1974). As microfracture porosity probably is only about 0.3 percent or less of each sample (p. 33), it was disregarded in converting calculated porosity to vesicularity. Vesicularity so calculated agrees closely with modal vesicularity measured in thin sections. In general, it decreased from 40 percent near the surface of the lake to a nearly constant 11 percent below $3 \mathrm{~m}$.

In detail, vesicularity did not decrease smoothly with depth. In at least some of the drill holes, it increased downward from the surface to maximum values in a highly cavernous layer at depths between 0.3 and 1.2 $m$ and then decreased with greater depth. During the drilling of several holes at these depths, the drill fell abruptly as much as a tenth of a meter. Little core was recovered from this interval from any of the drill holes, particularly from a depth of 0.3-0.6 m. Caverns at shallow depth were detected by stamping on the surface during a detailed study of surface features and joint cracks (Peck and Minakami, 1968, fig. 3; Peck and Kinoshita, 1976, fig. 33). Fifteen cavities were detected in an area approximately 100 feet $(30.5 \mathrm{~m})$ square. The cavities were beneath the central parts of the broad hummocks that made up the surface of the lake and were formed near the end of the eruption by the entrapment of rising gases below a thin surface crust. The appearance of similar features in older flows exposed on crater walls and roadcuts suggests that the cavities in Alae were lensoid openings a few tenths of a meter high and a meter or two in diameter. Below the cavernous layer to depths of about $5 \mathrm{~m}$, the lava consisted of vague, alternating layers of more and less vesicular basalt a few centimeters or fractions of a centimeter in thickness. In general, the width of the vesicular layers decreased and the spacing between the layers increased with depth. They were sparse below 3 $\mathrm{m}$ and disappeared at a depth of about $5 \mathrm{~m}$.

The size of vesicles in the lava increased from a minimum at the surface to a maximum at depths of about $30 \mathrm{~cm}$, and then decreased with greater depth. The average size of the 10 largest vesicles in each core interval increased linearly from $2 \mathrm{~mm}$ at the surface to $8 \mathrm{~mm}$ at a depth of $0.3 \mathrm{~m}$, as shown in figure 17. Below $0.3 \mathrm{~m}$, the average size of the largest vesicles decreased, reaching a minimum of about $1 \mathrm{~mm}$ between 6 and $12 \mathrm{~m}$ and increasing slightly near the base of the lake. The vesicles were round to spheroidal in the upper meter of glass-rich basalt, but the more com-

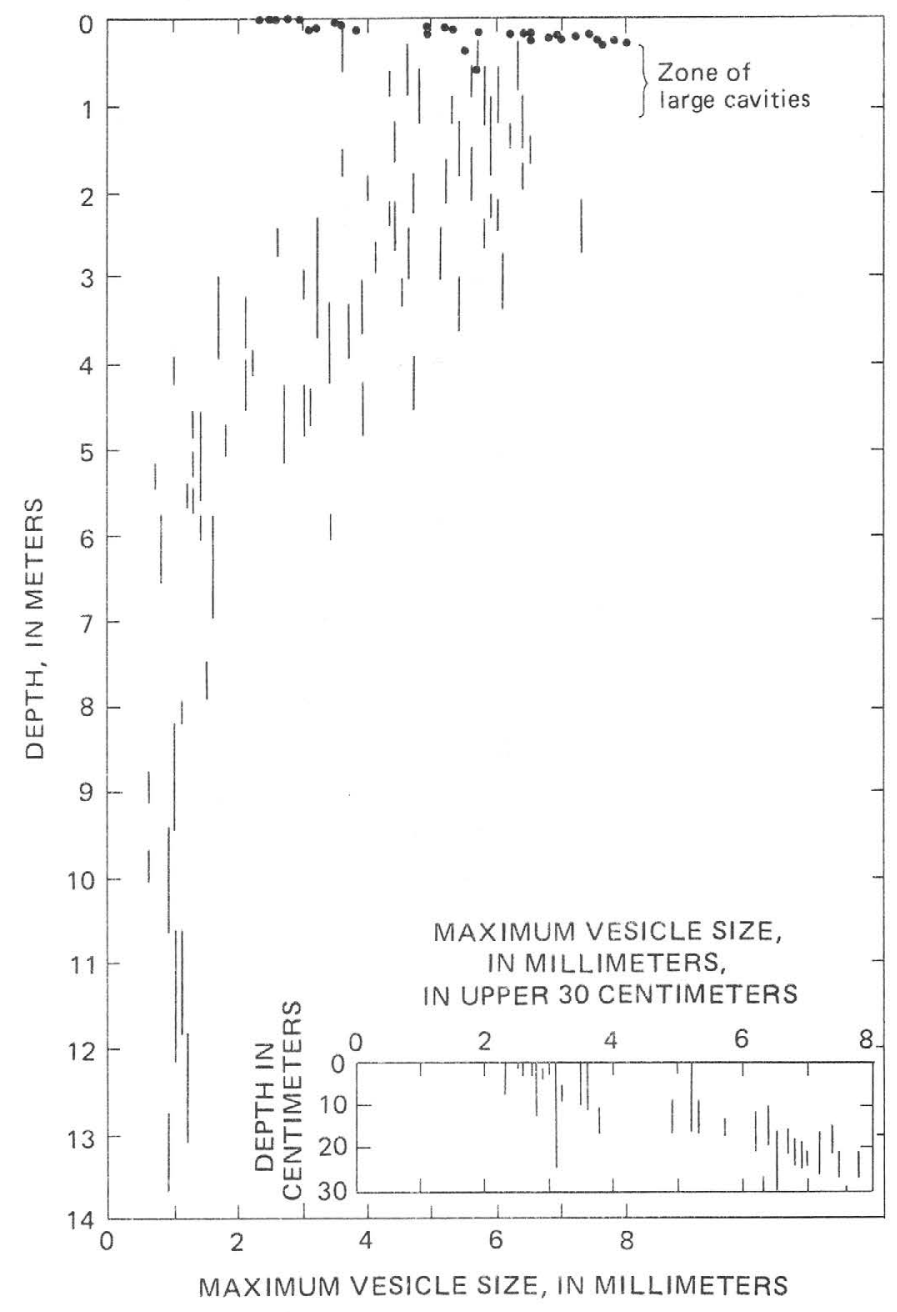

Figure 17.-Maximum size of vesicles as a function of depth.

pletely crystallized basalt at greater depths contained increasingly abundant minute angular vesicles, the voids characteristic of diktytaxitic texture. Below $6 \mathrm{~m}$ the vesicles were almost entirely of the minute angular type. Both types of vesicles are shown in the photomicrograph of figure 18 , which was taken of core collected November 17, 1964, from a depth of 1.5-2.1 m in drill hole 12.

The large, round vesicles apparently formed at high temperatures in relatively fluid lava, most of them probably at temperatures of approximately $1,100^{\circ} \mathrm{C}$ or more, and their decrease in abundance with depth in the lake recorded the degassing and approach to equilibrium gas content of the Alae lava. The lava was supersaturated with gas on eruption because of the decrease in confining pressure from the magma conduits to the surface. The relative rate of degassing with time can be estimated by comparing the change in vesicularity with depth to the change in depth with time of the $1,100^{\circ} \mathrm{C}$ isotherm. As shown in figure 19 , this comparison suggests that the rate of degassing decreased 


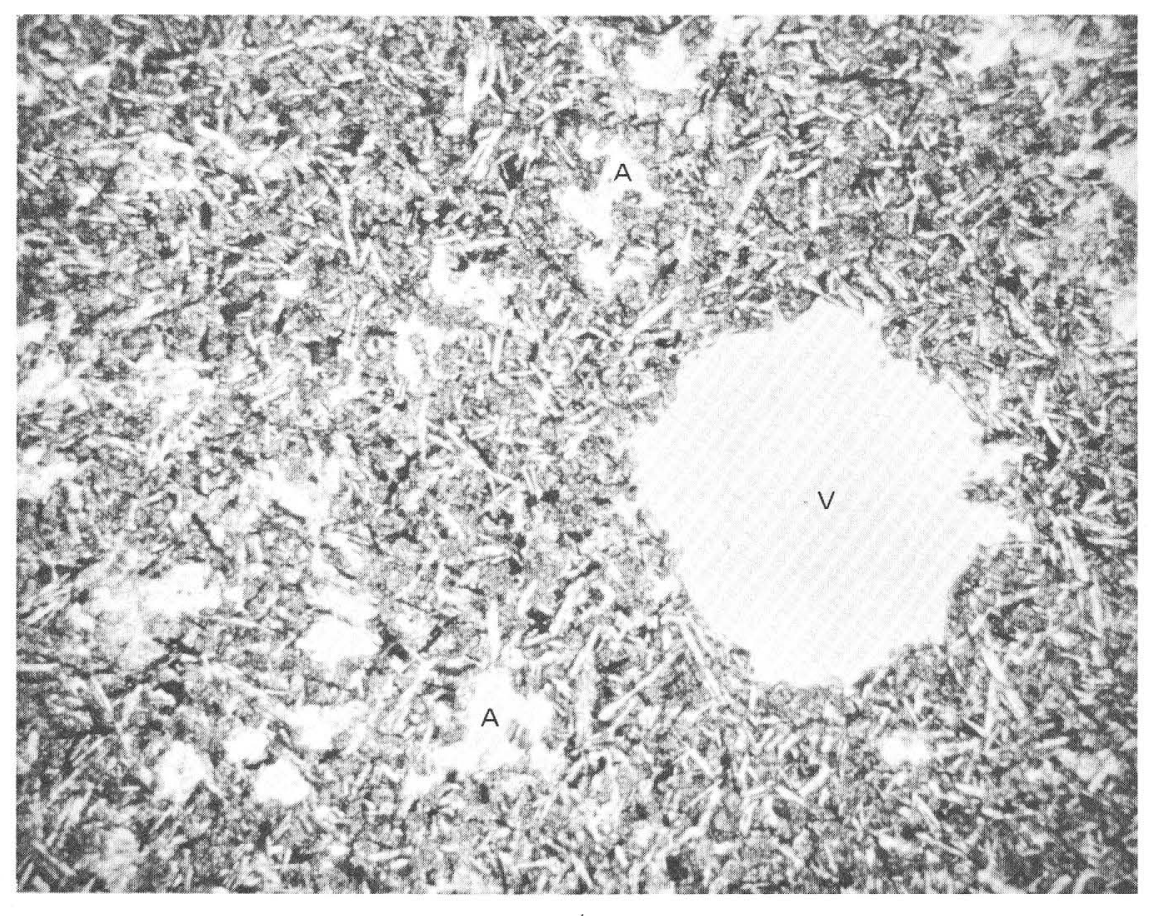

A

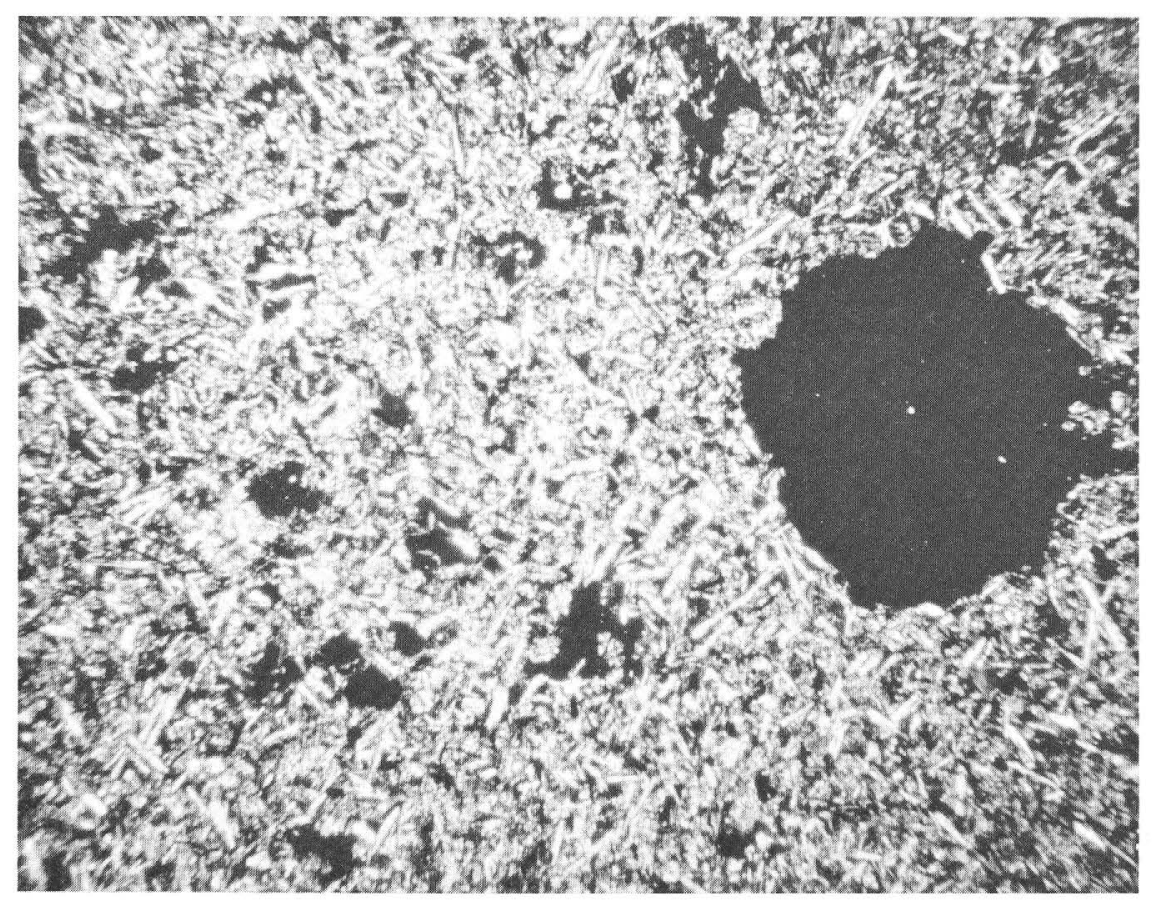

$B$

Figure 18.-Photomicrograph of vesicular basalt from a depth of 1.5-2.1 $\mathrm{m}$ in drill hole 12. A, plane-polarized light. $B$, Crossed nicols. The smooth round vesicle (V), a millimeter in diameter, presumedly formed from gas exsolved from the supersaturated fluid lava at temperatures of $1,100^{\circ} \mathrm{C}$ or more; minute angular vesicles (A) formed at lower temperatures in the transient zone of crystallization from gas driven out of solution by crystallization. 


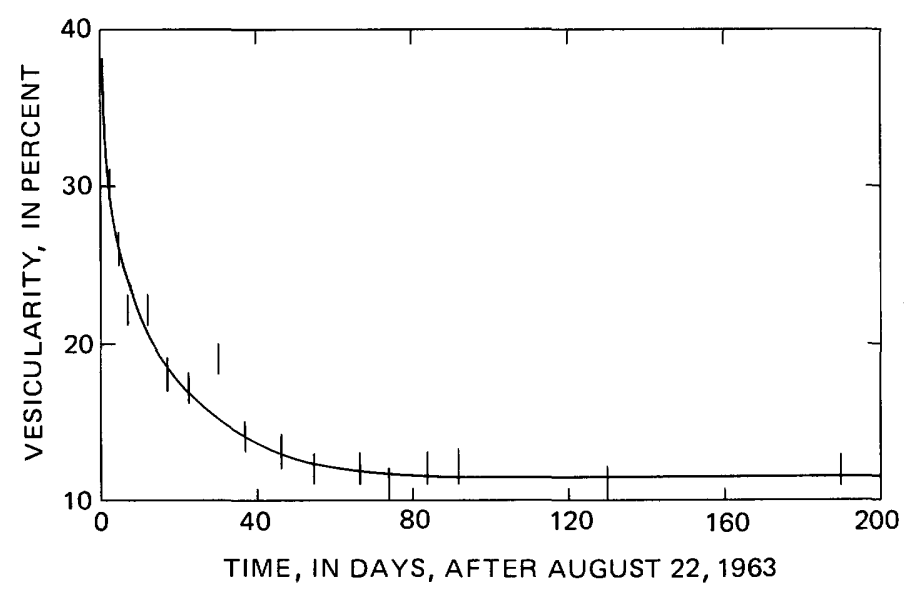

Figure 19.-Vesicularity of depth intervals in the upper part of the crust of Alae lava lake as a function of the time for each interval to cool to $1,100^{\circ} \mathrm{C}$. Vertical bars indicate the vesicularity of depth intervals that are $0.3 \mathrm{~m}$ thick in the upper $4.5 \mathrm{~m}$ and $1.5 \mathrm{~m}$ thick below. The plot records the strong degassing of the Alae lava during the first 30 days after the eruption.

drastically during the first 30 days, during which time the upper 2.5 meters of the lake cooled to less than $1,100^{\circ} \mathrm{C}$; thereafter, gas from the slightly oversaturated fluid lava slowly exsolved until the lava reached an equilibrium gas content approximately 100 days after the eruption, when the upper $4.5 \mathrm{~m}$ had cooled to less than $1,100^{\circ} \mathrm{C}$. Rapid degassing of the ponded lava in Makaopuhi crater during the first 4 months after the March 1965 eruption was demonstrated by Finlayson, Barnes, and Naughton (1968, fig. 5); they determined by chemical analysis the rapid depletion of carbon and sulfur in gas collected from drill holes in the crust of the lake.

The size and shape of the minute angular pores and their rather constant abundance from top to bottom in the solidified lake suggest that they formed at lower temperatures than the spheroidal vesicles and near the crust-fluid lava interface, where growth of vesicles was constrained by a meshwork of crystals and higher viscosity melt. The vesicles apparently formed from gases exsolved from the melt because of the crystallization of anhydrous minerals--that is, "second boiling" of the melt. The rather constant 11 percent vesicularity at depths below $3 \mathrm{~m}$ would represent 0.0025 percent gas by weight, assuming the gas were water vapor. The relative abundance of the angular pores at different temperatures within the zone of crystallization could not be determined from the drill core because core from the zone also contains vesicles formed from vaporized coolant water. The natural abundance of the angular pores with temperature and the rate of vesiculation within the zone, however, can be estimated from the rate of crystallization with temperature. The estimated

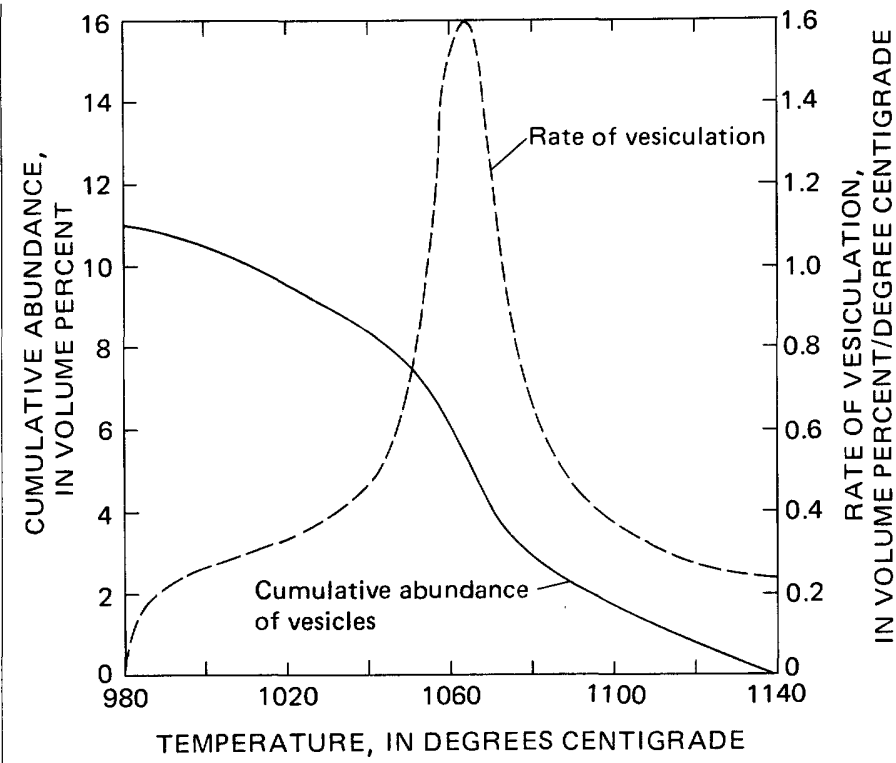

FIGURE 20.-Estimated rate of vesiculation (dashed curve) and cumulative abundance of minute angular vesicles (solid curve) as a function of temperature.

rate of vesiculation and the cumulative abundance of vesicles (fig. 20) are based on petrographic observations of crystal abundance and calculations from chemical analyses of samples from Alae and Makaopuhi lava lakes (Wright and Peck, 1978). The calculations suggest that the maximum rate of vesiculation (1.6 percent vesicles formed for a $1^{\circ} \mathrm{C}$ drop in temperature) took place between 1,060 and $1,065^{\circ} \mathrm{C}$, and that two-thirds of the vesicles were formed between $1,100^{\circ} \mathrm{C}$ and $1,030^{\circ} \mathrm{C}$. A strong peak of vesiculation at 1,060 $1,065^{\circ} \mathrm{C}$ is confirmed by calculations (p. 34) that show good agreement between the observed uplift during solidification at the main drilling site and the uplift calculated on the assumption that vesiculation took place at $1,065^{\circ} \mathrm{C}$.

\section{ALTITUDE OF THE LAKE SURFACE}

Repeated surveys of the altitude of a grid of stations on the lake surface over the 4-year period of solidification and continued cooling reveal a complex, changing pattern of uplift and subsidence. During the year of solidification, the surface above the thick central part of the lake rose as much as $25 \mathrm{~cm}$ and the margin subsided as much as $6 \mathrm{~cm}$. During the following 3 years of continued cooling, the entire lake surface subsided. Interpretation of the changes in altitude involves not only analysis of the leveling data but also integration of that data with temperature measurements, surveys of horizontal extension and contraction of the lake surface, and data on density and vesicularity of the crust of the lake. Accordingly, data on the altitude and hori- 

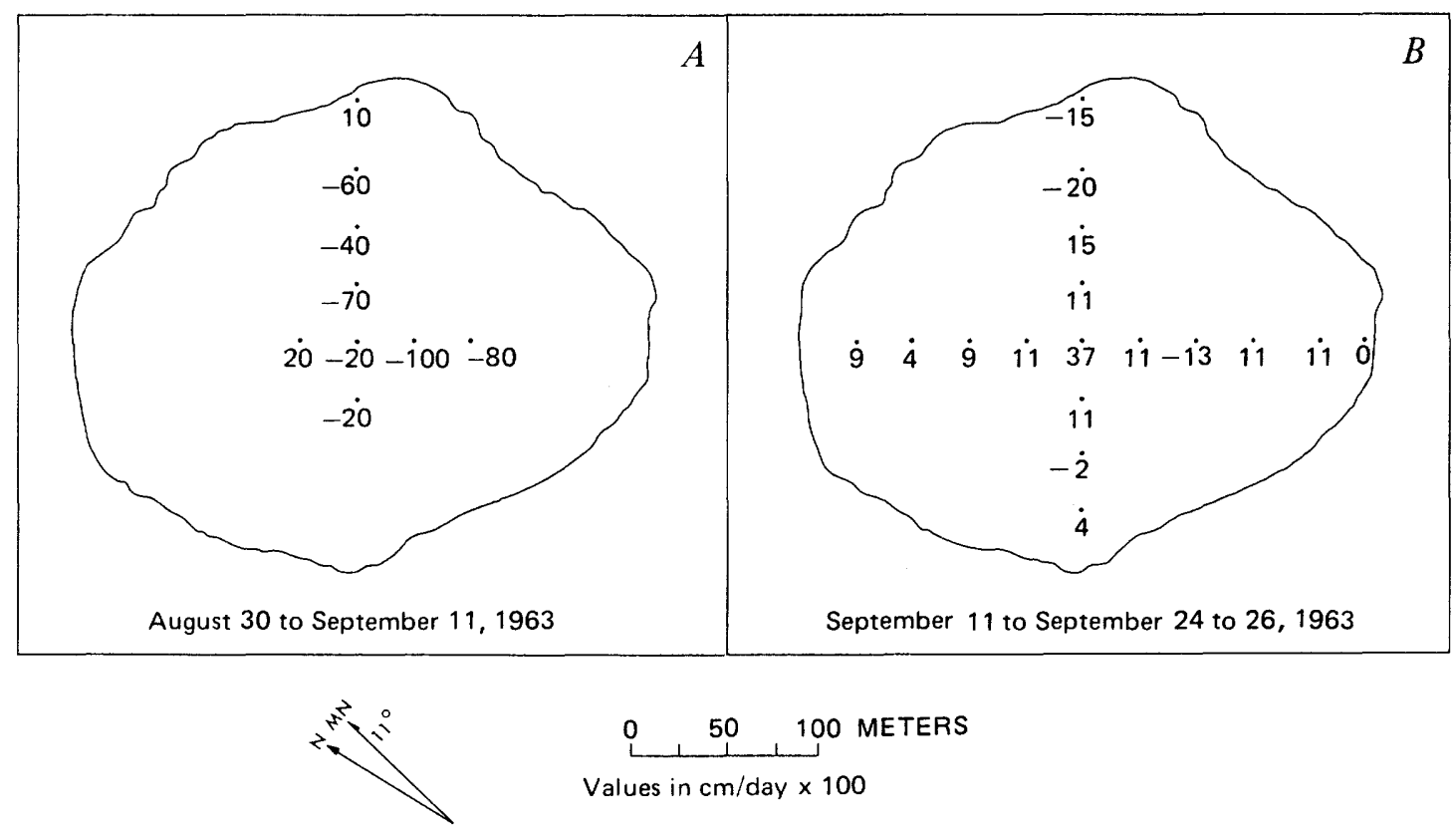

FIGURE 21.-Rate of change in altitude of the surface of Alae lava lake during solidification of the lake from August 30 to September $24-26,1963$. Values are in $\mathrm{cm} /$ day $\times 10^{2}$. $A$, August 30 to September 11,$1963 ; B$, September 11 to September 24-26, 1963.

zontal separation of stations are presented first, followed by interpretations of the recorded changes.

\section{CHANGES IN ALTITUDE DURING SOLIDIFICATION}

On August 30,1963, 7 days after the eruption, the altitudes of nine stations on the lake were measured approximately. ${ }^{2}$ When they were remeasured 12 days later on September 11, seven of them had subsided, decreasing in altitude as much as $12.2 \mathrm{~cm}$, as shown in figure $21 \mathrm{~A}$ and listed in table 6 . The full cross of 17 stations was leveled on September 11 and again September 24-26. During the 2-week interval, most of the stations near the edge of the lake subsided, and most of those near the center were uplifted (fig. $21 B$ ). The greatest uplift was $5.2 \mathrm{~cm}$ at station 5 , near the center of the lake.

The complete grid of stations was established and their relative altitudes measured September 24-26, and at monthly intervals for the following year while the lake continued to solidify. Changes in altitude are plotted and contoured as rates of change per day for six bimonthly periods in figure 22 . The average rate of uplift of all stations was greatest during October and November $1963(0.08 \mathrm{~cm} /$ day $)$ and fell steadily thereafter to $0.05 \mathrm{~cm} /$ day for March and April 1964, 0.02 $\mathrm{cm} /$ day for June and July, and $0.003 \mathrm{~cm} /$ day for August and September. The relative changes of altitude of the

${ }^{2}$ As described in the section on methods of study, p. 7, the initial survey was conducted with a damaged transit, and the measured altitudes may be in error by as much as $1.5 \mathrm{~cm}$. different stations on the lake showed a consistent pattern during each bimonthly period of the year. The margin of the lake subsided and the central part rose. The line between areas of uplift and subsidence migrated inward, very slowly during the first 6 months but more rapidly during the rest of the year. Uplift was not constant over the central part of the lake. During the first 8 months it was greatest in a belt part way between the center and the edge of the lake. During the last 4 months, the greatest uplift was near the center of the lake. Comparison of the patterns of uplift and subsidence with the contour map of the base of the lake (fig. 1) suggests a relationship between changes in altitude and the depth of the lake. This relationship can be seen most clearly in the changes during April to June 1964 (fig. 22 D), when the ring of maximum uplift and the line between uplift and subsidence bent inward where the northern part of the lake thinned over a buried 1840 spatter ridge and where the southeast part thinned over a less pronounced ridge.

Several stations were added during the year to determine whether differences in altitude changes between stations of the grid took place smoothly or abruptly with distance. Two stations (37 and 38 ) were marked in early December 1963 on the crests of small tumuli near station 4 at the center of the lake, and five stations (42 through 46) were added in early January 1964 on the north-central part of the lake between stations 3 and 29. Repeated level measurements over the following 6 months showed no abrupt changes in altitude between these closely spaced stations. 
TABLE 6.-Altitude of stations on the lake surface

[Altitudes given in feet above sea level ( 1 foot $=0.3048 \mathrm{~m}$ ). Figures in parentheses show change in altitude between dates]

\begin{tabular}{|c|c|c|c|c|c|c|c|}
\hline \multicolumn{2}{|c|}{ Station } & \multicolumn{2}{|l|}{ Aug. 30,1963} & \multicolumn{2}{|l|}{ Sept. 11, 1963} & \multicolumn{2}{|l|}{ Sept. $24-26,1963$} \\
\hline 1 & ---------- & $-\ldots--$ & -.- & 2566.98 & $(+0.04)$ & 2567.015 & $(+0.027)$ \\
\hline 2 & - - - - & -.--- & $\ldots$ & 66.43 & $(+.02)$ & 66.453 & $(+.117)$ \\
\hline 3 & $-\ldots \ldots-1--$ & & --- & 65.75 & $(+.04)$ & 65.793 & $(+.041)$ \\
\hline 4 & ---------- & 2566.22 & $(+0.07)$ & 66.29 & $(+.06)$ & 66.346 & $(+.094)$ \\
\hline 5 & --------- & 67.08 & $(-.06)$ & 67.02 & $(+.17)$ & 67.190 & $(+.153)$ \\
\hline 6 & $---1-\ldots-n$ & 66.85 & $(-.40)$ & 66.45 & $(+.05)$ & 66.498 & $(+.134)$ \\
\hline 7 & $---1---1-$ & 66.93 & $(-.32)$ & 66.61 & $(-.06)$ & 66.545 & $(+.082)$ \\
\hline 8 & $-------\cdots--$ & $+\ldots--$ & $-\ldots$ & 67.93 & $(+.05)$ & 67.981 & $(+.132)$ \\
\hline 9 & ---------- & $---1--$ & --- & 66.70 & $(+.05)$ & 66.751 & $(+.057)$ \\
\hline 11 & $---1--1-1$ & 65.07 & $(+.03)$ & 65.10 & $(-.07)$ & 65.029 & $(-.062)$ \\
\hline 12 & - - - & 2568.10 assumed & - & 68.10 & $(-.11)$ & 67.989 & $(-.009)$ \\
\hline 13 & - - - & 67.05 & $(-.24)$ & 66.81 & $(-.09)$ & 66.721 & $(+.131)$ \\
\hline 14 & 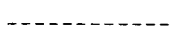 & 67.14 & $(-.16)$ & 66.98 & $(+.07)$ & 67.050 & $(+.087)$ \\
\hline 15 & 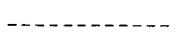 & 66.96 & $(-.28)$ & 66.68 & $(+.05)$ & 66.726 & $(+.122)$ \\
\hline 16 & $-\ldots---\ldots---$ & 66.51 & $(-.06)$ & 66.45 & $(+.05)$ & 66.495 & $(+.097)$ \\
\hline 17 & $--1-\ldots-1$ & $-\ldots-$ & --- & 67.04 & $(-.01)$ & 67.028 & $(+.030)$ \\
\hline 18 & 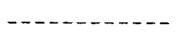 & ---- & --- & 65.58 & $(+.02)$ & 65.60 & $(+.032)$ \\
\hline 19 & $--1---1--$ & $\ldots \ldots$ & $\ldots$ & 2568.09 assumed & $\ldots$ & 2568.09 assumed & $\ldots$ \\
\hline 20 & $-\ldots-\ldots---$ & ---- & --- & $-\cdots--$ & --- & 66.781 & $(+.100)$ \\
\hline 21 & $---1----$ & $---1-$ & --- & ---- & --- & 66.649 & $(+.153)$ \\
\hline 22 & $-\ldots \ldots--\ldots$ & $-\ldots-\cdots$ & --- & $---\cdots$ & $\ldots$ & 66.513 & $(+.177)$ \\
\hline 23 & $-\ldots+------$ & $-\cdots-$ & $-\ldots$ & 68.60 & $(0)$ & 68.604 & $(-.052)$ \\
\hline 24 & ---------- & ---- & $\ldots$ & - - - - & $\ldots$ & 67.195 & $(+.116)$ \\
\hline 25 & ---------- & ---- & $-\ldots$ & $\ldots \ldots$ & ---- & 67.701 & $(+.069)$ \\
\hline 26 & ------- & $\ldots-\ldots$ & $\ldots$ & $-\ldots-1$ & --- & 67.086 & $(+.082)$ \\
\hline 27 & $---1--1-1$ & $\ldots-\ldots$ & $-\ldots$ & $-\ldots-1$ & $\ldots$ & 68.026 & $(+.113)$ \\
\hline 28 & $\ldots \ldots$ & $-\ldots \ldots$ & $-\ldots$ & 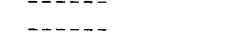 & $-\ldots$ & 66.613 & $(+.016)$ \\
\hline 29 & - - & $-\ldots--$ & $-\ldots$ & $-\ldots-n$ & $\ldots$ & 66.411 & $(+.227)$ \\
\hline 30 & - & $-\ldots-1$ & $-\ldots$ & 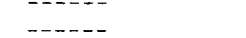 & $\ldots$ & 65.955 & $(+.073)$ \\
\hline 31 & - & $-\ldots-1$ & --- & $\begin{array}{ll}-2-n-1 \\
n-n\end{array}$ & $-\ldots--$ & 68.176 & $(-.088)$ \\
\hline 32 & 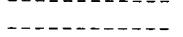 & 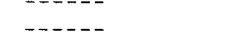 & ---- & 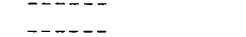 & --- & 67.734 & $(-.052)$ \\
\hline 33 & - & - & --- & 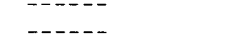 & $-\cdots$ & 66.868 & $(+.146)$ \\
\hline 34 & - - & $-\ldots-n$ & --- & - & $-\ldots$ & 67.485 & $(-.113)$ \\
\hline 35 & $---1--1--$ & ----- & --- & $---n$ & $-\cdots$ & 67.814 & $(-.005)$ \\
\hline 37 & $-\cdots-\cdots---$ & $\ldots-\cdots$ & $-\cdots$ & ---- & --- & $\ldots \ldots$ & - \\
\hline 38 & $---1-n---$ & ----- & --- & $\ldots \ldots$ & ---- & $-\ldots--$ & $\ldots$ \\
\hline 41 & $----\ldots---$ & $-\cdots--$ & $\ldots$ & ----- & --- & $\ldots-\ldots$ & $\ldots$ \\
\hline 47 & $--------1--$ & ----- & --- & ------ & --- & $-\ldots--$ & $-\cdots$ \\
\hline \multicolumn{2}{|c|}{ Station } & Oct. 30,1963 & & Dec. 4,1963 & & Jan. 2, 1964 & \\
\hline 1 & $---1-\ldots-1$ & 2567.042 & $(+0.070)$ & 2567.112 & $(+0.030)$ & 2567.142 & $(+0.092)$ \\
\hline 2 & 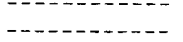 & 66.570 & $(+.108)$ & 66.678 & $(+.053)$ & 65.731 & $(+.079)$ \\
\hline 3 & $-----1---$ & 65.834 & $(+.073)$ & 65.907 & $(+.025)$ & 65.932 & $(+.088)$ \\
\hline 4 & $---1--1-2-1$ & 66.440 & $(+.129)$ & 66.569 & $(+.019)$ & 66.588 & $(+.083)$ \\
\hline 5 & $-\ldots-\ldots--\infty$ & 67.343 & $(+.062)$ & 67.405 & $(+.002)$ & 67.407 & $(+.053)$ \\
\hline 6 & -----+---1 & 66.632 & $(+.079)$ & 66.711 & $(+.025)$ & 66.736 & $(+.064)$ \\
\hline 7 & $--\ldots-1--n-n$ & 66.627 & $(+.033)$ & 66.660 & $(+.032)$ & 66.692 & $(+.053)$ \\
\hline 8 & n----------- & 68.113 & $(+.140)$ & 68.253 & $(+.103)$ & 68.356 & $(+.139)$ \\
\hline 9 & - & 66.808 & $(+.092)$ & 66.900 & $(+.076)$ & 66.976 & $(+.104)$ \\
\hline 11 & - $-\ldots-\ldots-\ldots$ & 64.967 & $(+.001)$ & 64.968 & $(-.011)$ & 64.957 & $(+.010)$ \\
\hline 12 & - & 67.980 & $(+.023)$ & 68.003 & $(-.010)$ & 67.993 & $(+.006)$ \\
\hline 13 & $-1-1-1--$ & 66.852 & $(+.132)$ & 66.984 & $(+.082)$ & 67.066 & $(+.127)$ \\
\hline 14 & - $-\ldots-\ldots-\ldots$ & 67.137 & $(+.049)$ & 67.186 & $(+.037)$ & 67.223 & $(+.056)$ \\
\hline 15 & - $-1-2-1-2-1-1$ & 66.848 & $(+.056)$ & 66.904 & $(+.018)$ & 66.922 & $(+.057)$ \\
\hline 16 & $-------\cdots$ & 66.592 & $(+.111)$ & 66.703 & $(+.038)$ & 66.741 & $(+.056)$ \\
\hline 17 & $--\ldots-1-\ldots$ & 67.058 & $(+.099)$ & 67.157 & $(+.063)$ & 67.220 & $(+.071)$ \\
\hline 18 & $------1----$ & 65.632 & $(+.040)$ & 65.672 & $(+.033)$ & 65.705 & $(+.055)$ \\
\hline 19 & $--------\infty$ & 2568.09 assumed & --- & 2568.09 assumed & $\ldots$ & 2568.09 assumed & - \\
\hline 20 & ---------- & 66.881 & $(+.074)$ & 66.955 & $(+.041)$ & 66.996 & $(+.107)$ \\
\hline 21 & -n- - - & 66.802 & $(+.145)$ & 66.947 & $(+.042)$ & 66.989 & $(+.121)$ \\
\hline 22 & -.-- - & 66.690 & $(+.137)$ & 66.827 & $(-.003)$ & 66.824 & $(+.095)$ \\
\hline 23 & +--------- & 68.552 & $(-.032)$ & 68.520 & $(-.022)$ & 68.498 & $(-.016)$ \\
\hline 24 & ---------- & 67.311 & $(+.115)$ & 67.426 & $(+.040)$ & 67.466 & $(+.078)$ \\
\hline 25 & ----------- & 67.770 & $(+.070)$ & 67.840 & $(+.030)$ & 67.870 & $(+.095)$ \\
\hline 26 & $-\ldots---1-\ldots$ & 67.168 & $(+.139)$ & 67.307 & $(+.043)$ & 67.350 & $(+.088)$ \\
\hline 27 &.---------- & 68.139 & $(+.106)$ & 68.245 & $(+.074)$ & 68.319 & $(+.117)$ \\
\hline 28 & - & 66.629 & $(+.104)$ & 66.733 & $(+.057)$ & 66.790 & $(+.150)$ \\
\hline 29 & 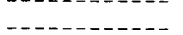 & 66.638 & $(+.119)$ & 66.757 & $(+.012)$ & 66.769 & $(+.111)$ \\
\hline 30 & - $-2-1-2-1-1$ & 66.028 & $(+.107)$ & 66.135 & $(+.051)$ & 66.186 & $(+.102)$ \\
\hline 31 & 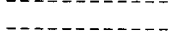 & 66.088 & $(-.028)$ & 68.060 & $(-.024)$ & 68.036 & $(-.024)$ \\
\hline 32 & - & 67.682 & $(-.003)$ & 67.679 & $(+.002)$ & 67.681 & $(+.027)$ \\
\hline 33 & - - - - - - - - - - & 67.014 & $(+.101)$ & 67.115 & $(+.038)$ & 67.153 & $(+.101)$ \\
\hline 34 & - - - - & 67.372 & (0) & 67.372 & $(-.027)$ & 67.345 & $(+.020)$ \\
\hline 35 & 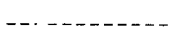 & 67.809 & $(+.063)$ & 67.872 & $(+.024)$ & 67.896 & $(+.061)$ \\
\hline
\end{tabular}


TABLE 6.-Altitude of stations on the lake surface-Continued

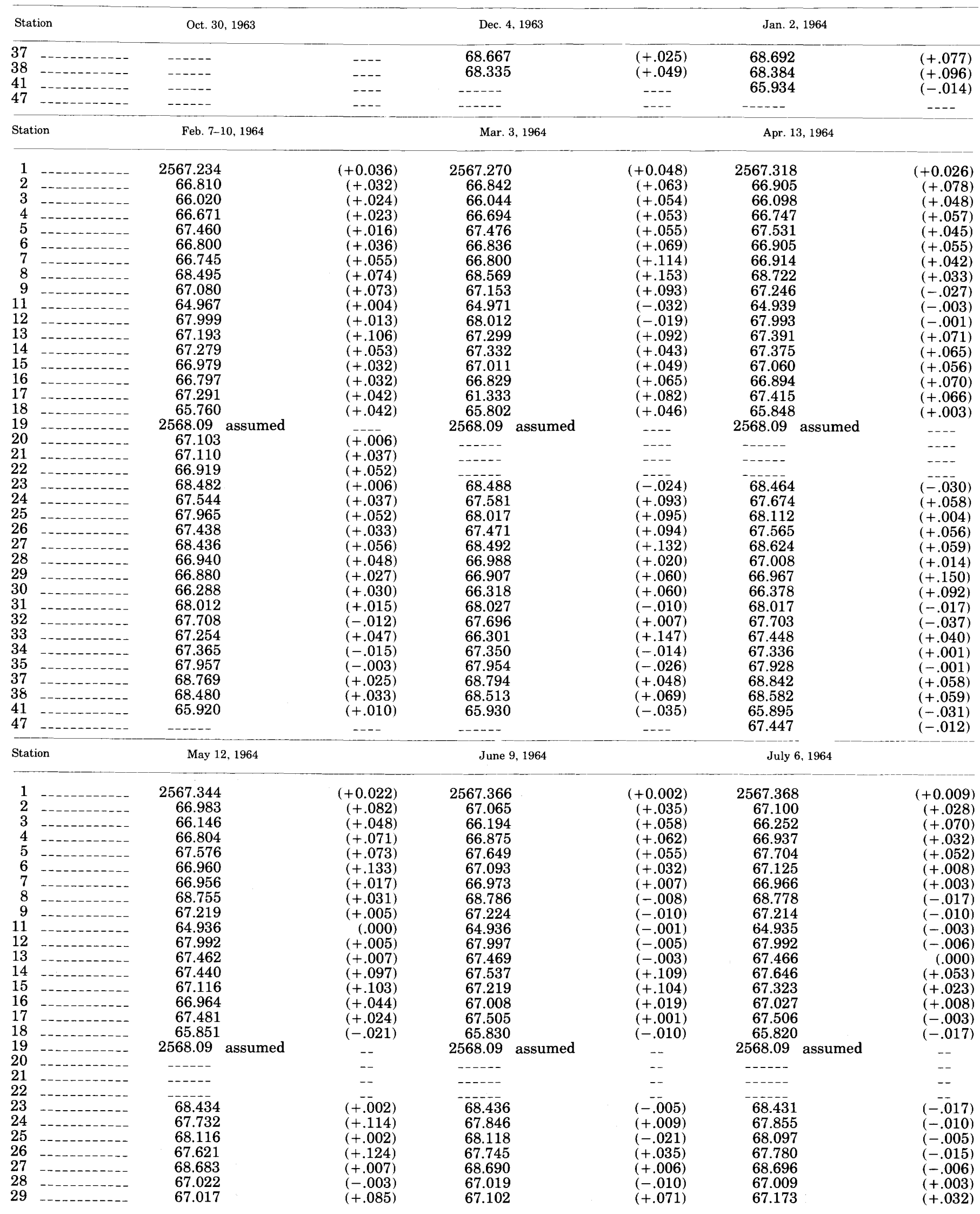


TABLE 6.-Altitude of stations on the lake surface-Continued

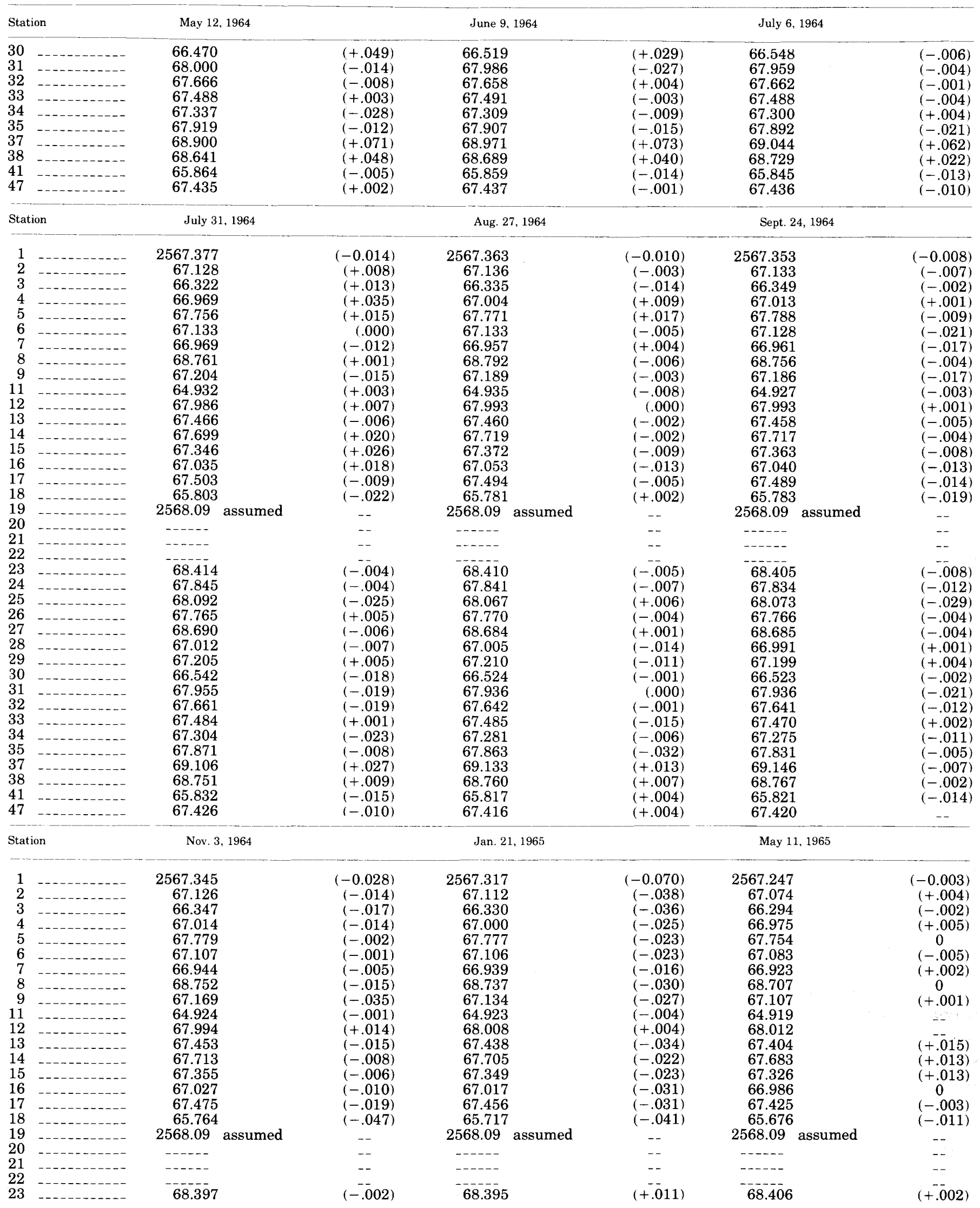


TABLE 6.-Altitudes of stations on the lake surface-Continued

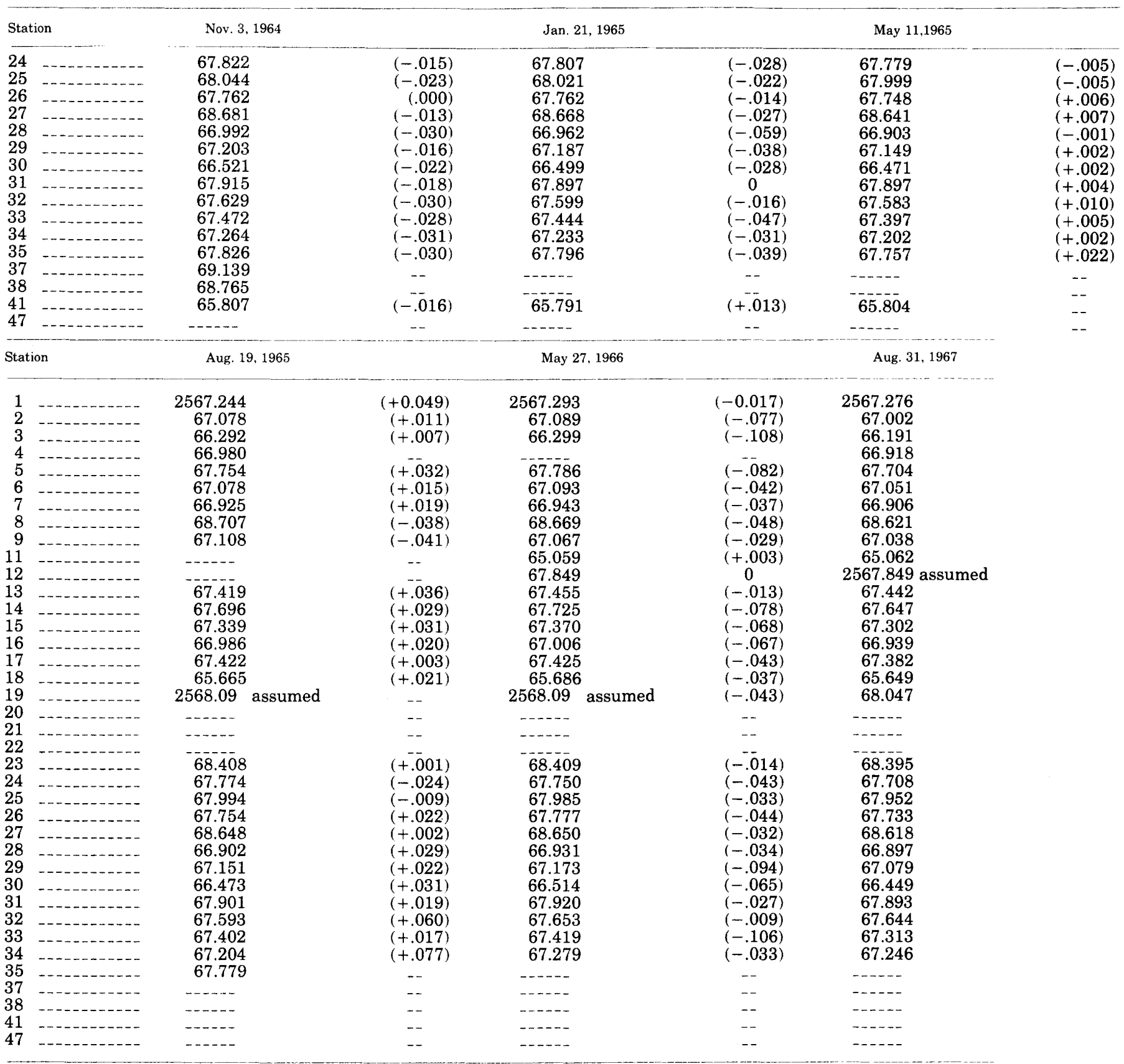

Cumulative changes in altitude of five representative stations on the lake are shown (fig. 23) as a function of time in days after the eruption. The stations include three $(18,23$, and 35$)$ within $30 \mathrm{~m}$ of the edge of the lake, one (29) about halfway between the center and edge, and one (15) near the center. Uplift of the station closest to the edge of the lake, 23, if it ever occurred, must have preceded the beginning of the survey. For the two other stations near the edge, subsidence followed uplift 200-300 days after the eruption. The two remaining stations show a pattern of changing altitude with time that was typical of almost all stations over the thick central part of the lake. During the second and third weeks after the eruption, station 15 subsided markedly, as did most of the few central stations surveyed. Thereafter, the stations were uplifted at a rate that decreased over the next several months to a nearly constant value. Shortly before the maximum uplift was reached, the rate of uplift increased to a high value for a month before quickly dropping to zero and to negative values.

The greatest cumulative uplift of the five stations was not at the stations near the center of the lake, but instead at station 29 , part way between the center and 

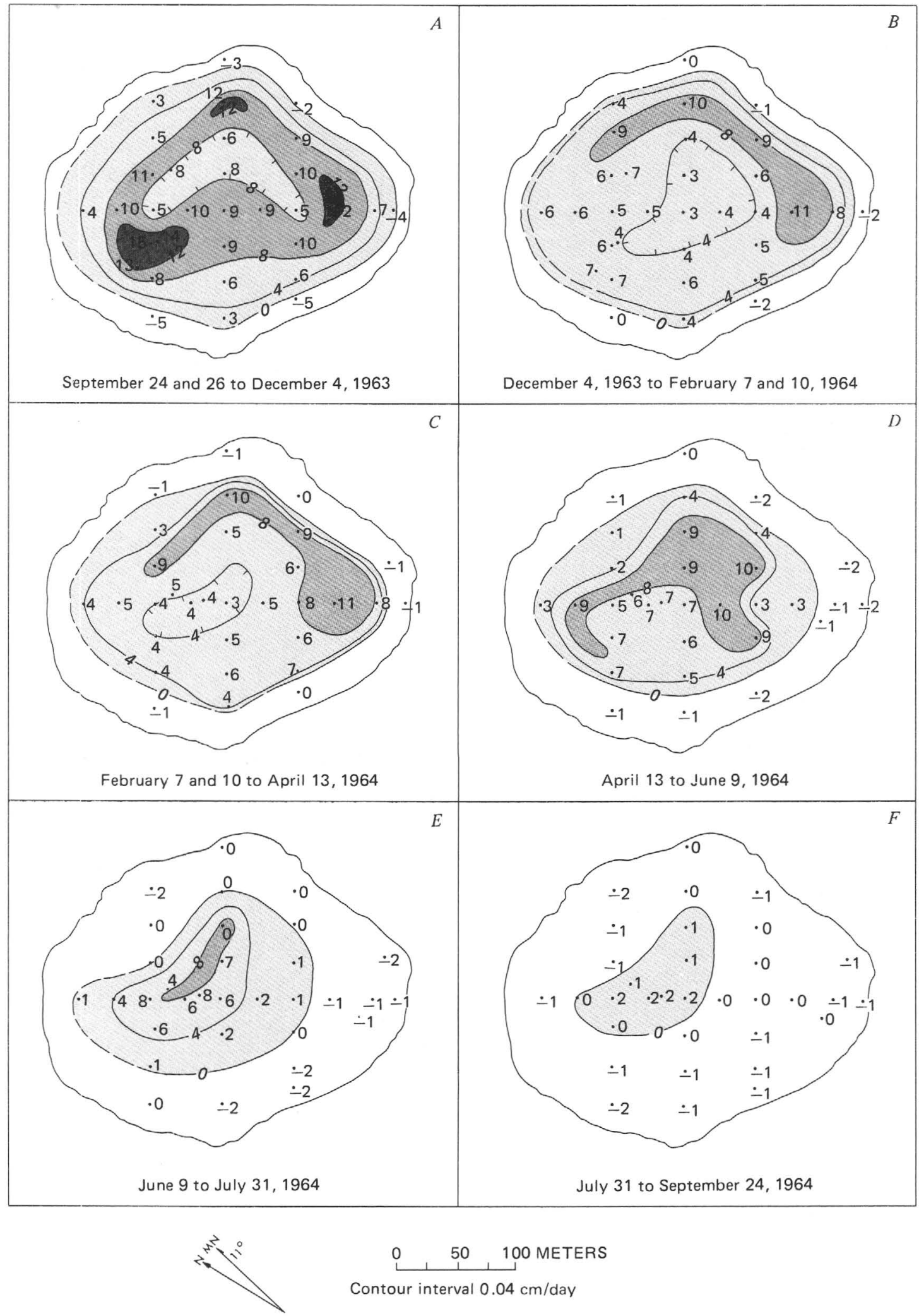

Contour interval $0.04 \mathrm{~cm} /$ day

FIGURE 22.-Rate of change in altitude of the surface of Alae lava lake during solidification of the lake from September 24-26, 1963, to September 24,1964. Values shown in centimeters per day $\times 10^{2}$. Shaded areas were uplifted during the leveling interval. $A$, September 24 and 26 to December 4, 1963. B, December 4, 1963, to February 7 and 10, 1964.C, February 7 and 10 to April 13, 1964.D, April 13 to June 9, 1964. E, June 9 to July 31 , 1964. F, July 31 to September 24, 1964. 


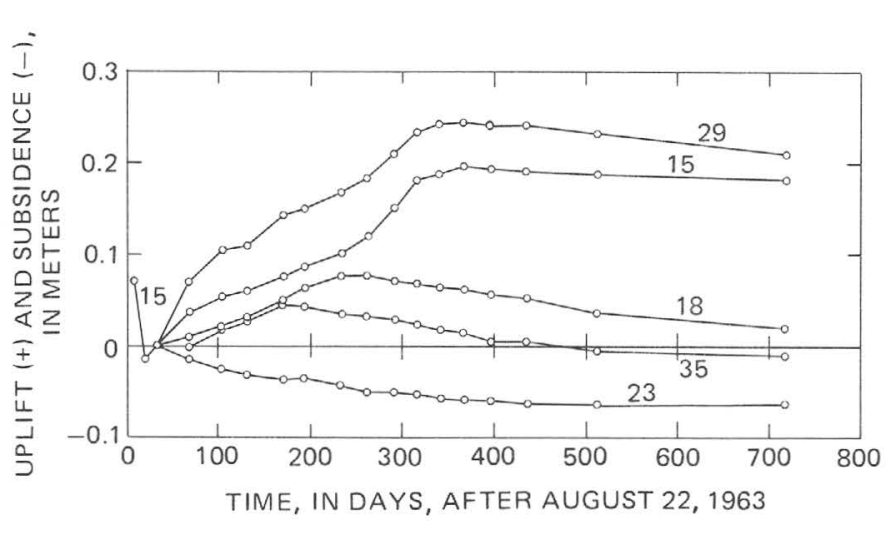

FIGURE 23.-Cumulative changes in altitude of five stations on the lake after September 24-26, 1963, as a function of time in days after August 22, 1963. Location of stations plotted in figure 1. Stations 18,23 , and 35 are within $30 \mathrm{~m}$ of the edge of the lake; station 29 is about $75 \mathrm{~m}$ from the edge; and station 15 is near the center and deepest part of the lake.

edge of the lake. A similar relationship for other stations on the lake is shown in figure 24 , on which is plotted the total cumulative uplift (later subsidence not subtracted) for the period September 24-26, 1963, to September 24, 1964, of all 29 main stations on the grid. The figure shows two areas of maximum uplift part way between the center and the eastern and western margins of the lake.

\section{CHANGES IN HORIZONTAL. DISTANCE DURING SOLIDIFICATION}

During the year that the lake solidified, distances

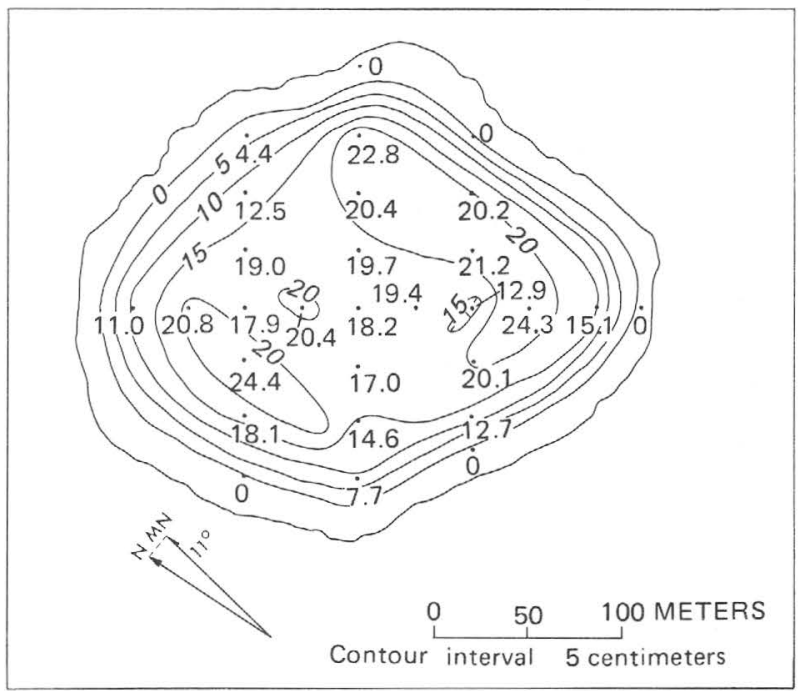

Figure 24.-Total uplift of the lake surface after September 24-25, 1963.

between stations on the surface of the lake also changed in a consistent manner. The first measurements of the distances were on August 30, and September 3 and 11, 1963. When the distances were remeasured on December 4 and 17, 1963, the crust of the central part and north edge of the lake had expanded, and that of most of the lake margin had contracted, as shown in figure $25 \mathrm{~A}$. The greatest change was an expansion of $32 \pm 1.8 \mathrm{~cm}$ between stations 3 and 4 . When the distances were remeasured on July 27,1964 , similar but much smaller changes were found (fig. 25B). An
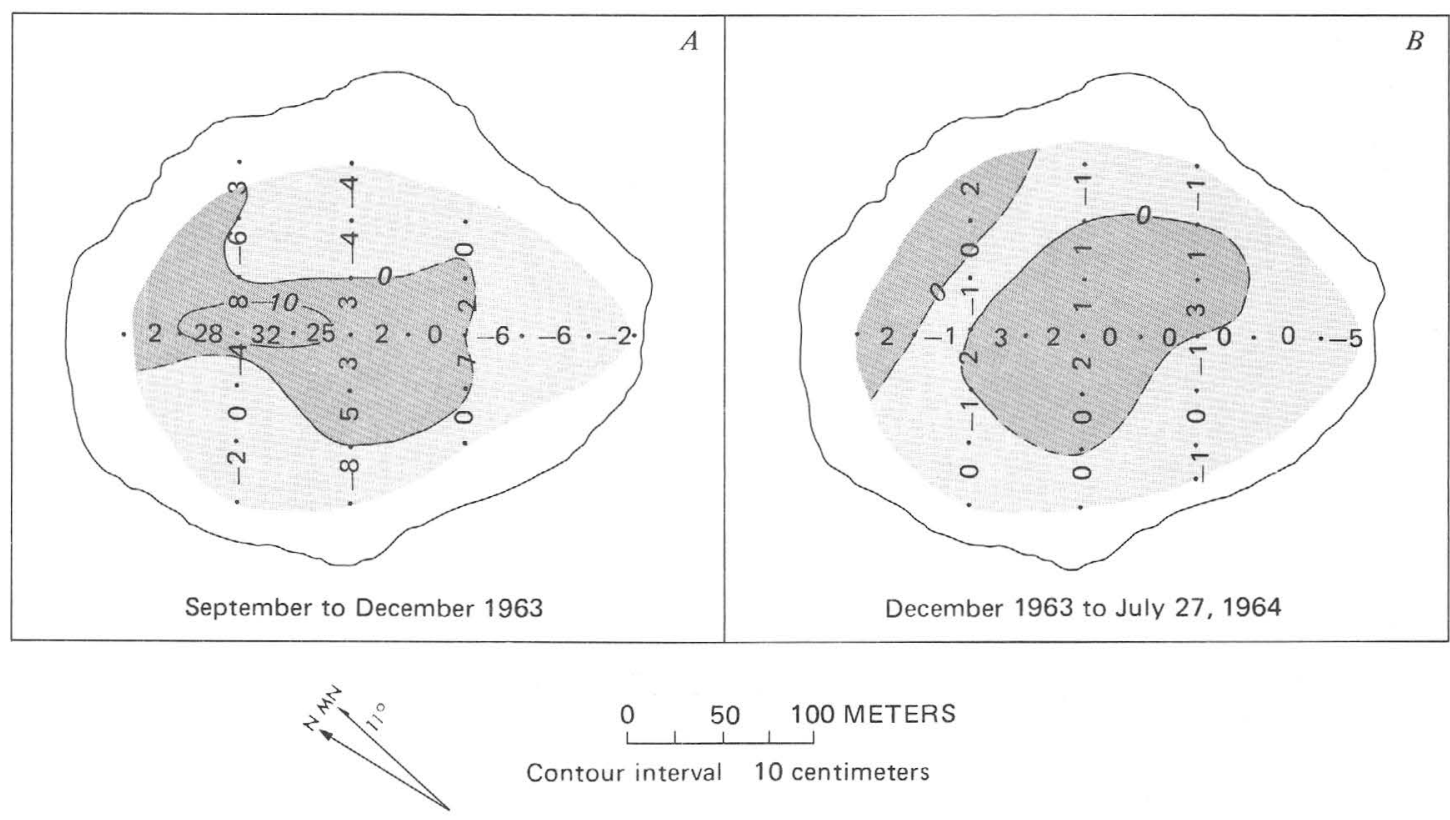

FIGURE 25.-Changes in horizontal distance between stations on the surface of Alae lava lake during solidification of the lake. $A$, Changes $1.5 \mathrm{~cm}$ and greater between September and December 1963. B, Changes greater than $0.6 \mathrm{~cm}$ between December 1963 and late July 1964. Areas that underwent expansion are more heavily shaded. 

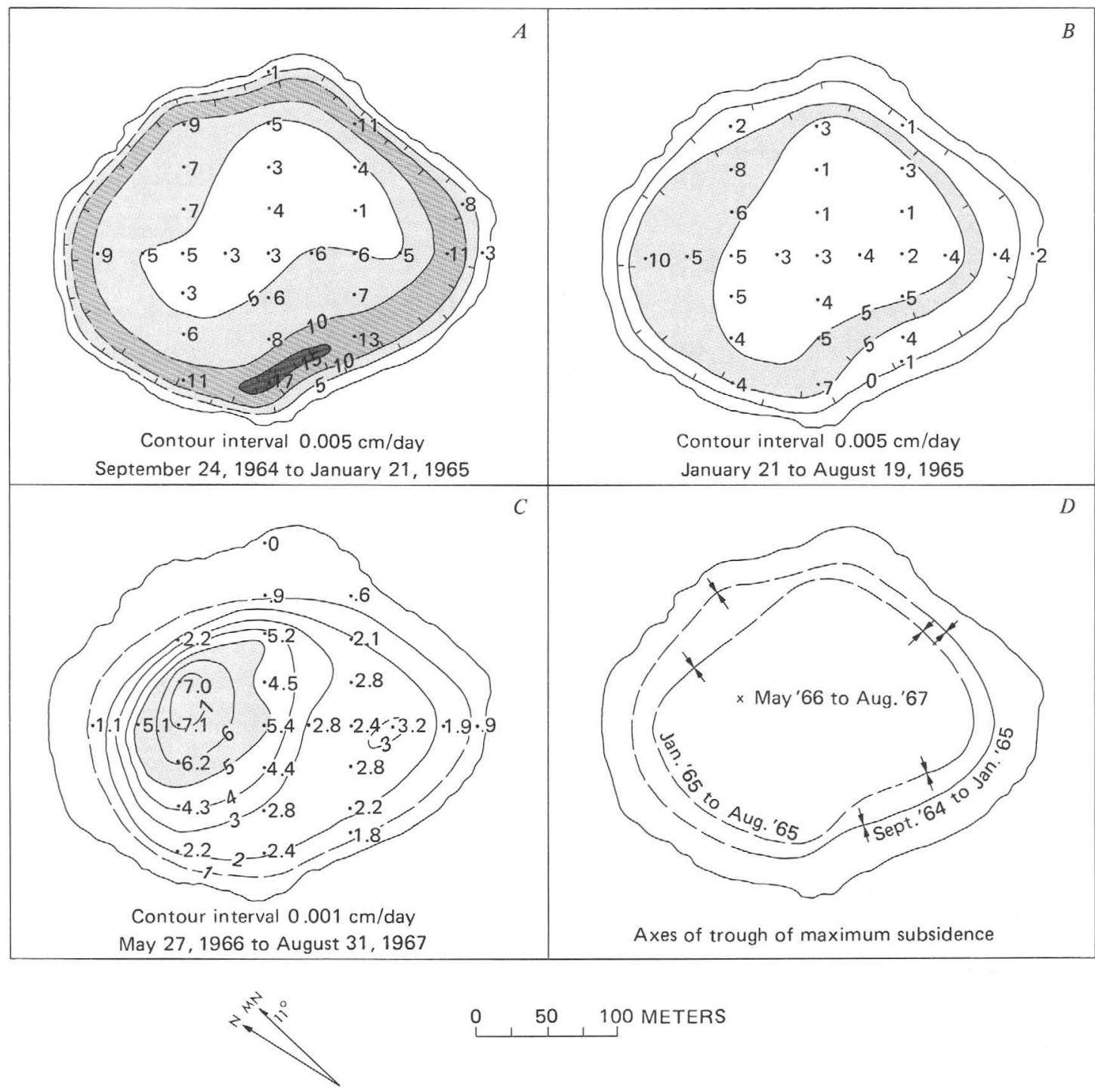

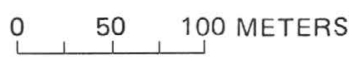

FIgURE 26.-Rate of subsidence of the lake surface after complete solidification in late September 1964. Values in centimeters per day $\times 10^{3} . A$, September 24,1964 to January $21,1965 . B$, January 21 to August 19, 1965. C, May 27, 1966 to August 31, 1967. D, Approximate positions of the axis of the belt of maximum subsidence between September 1964 and August 1965 and the point of maximum subsidence between May 1966 and August 1967. Areas that underwent subsidence of more than $0.005 \mathrm{~cm} /$ day are shaded.

area of expansion in the central part of the lake was surrounded by a ring of contraction, which in turn was bordered on the north by a marginal area of expansion. The greatest increase was $2.7 \pm 0.6 \mathrm{~cm}$ between stations 3 and 4 , and stations 7 and 26 . The greatest decrease was $5.2 \pm 0.6 \mathrm{~cm}$ between stations 9 and 23 .

\section{CHANGES IN ALTITUDE DURING FURTHER COOLING}

After the last interstitial melt in the lake solidified in late September 1964, the altitude of the surface continued to change. The entire surface of the lake subsided, falling an average of $0.006 \mathrm{~cm} /$ day between September 1964 and January 1965, $0.004 \mathrm{~cm} /$ day between January and August 1965, and $0.003 \mathrm{~cm} /$ day between
May 1966 and September 1967 (table 6). ${ }^{3}$ The rate of subsidence was not constant over the lake. From September 1964 to January 1965 and from January to August 1965 , subsidence was greatest in a belt part way between the center and the edge of the lake (fig. $26 \mathrm{~A}$ and $B$ ). This belt migrated inward approximately $15 \mathrm{~m}$ between the successive surveys (fig. 26D). Presumedly, the survey in May 1966, if it had been successful, would have disclosed a similar ring of maximum subsidence closer to the center of the lake. During the final leveling period (fig. 26C), the contours of equal subsid-

${ }^{3}$ The pattern and rate of subsidence between August 1965 and May 1966 is not known because the lake surface and base stations were shifted during an earthquake shortly before the survey of May 1966. 
ence form a rude bullseye pattern having the maximum subsidence over the deepest part of the lake near station 3.

\section{INTERPRETATION OF CHANGES IN ALTITUDE}

\section{SUBSIDENCE OF THE LAKE SURFACE AND CALCULATION OF THE COEFFICIENT OF THERMAL EXPANSION}

The processes causing subsidence of the surface after the lava lake had solidified will be discussed before taking up the more complex subject of altitude changes before complete solidification. Because fewer processes are involved-we can exclude lateral flowage of fluid lava and changes of bulk density upon crystallization and vesiculation - the interpretation is less ambiguous.

Subsidence of the surface after solidification of the lake is attributed to thermal contraction of the cooling basalt. The thermal contraction also caused the opening of joint cracks (Peck and Minakami, 1968; Peck and Kinoshita, 1976). However, as prehistoric Kilauean flows and lava lakes exposed in section show joints that are mostly or entirely vertical or nearly vertical rather than horizontal, the altitude of the Alae lake surface probably was affected little, if any, by jointing. As will be shown later, microfracturing of the basalt very probably took place during cooling, resulting in a decrease of both subsidence and thermal conductivity.

The effective bulk coefficient of thermal expansion of the Alae basalt can be calculated by comparing the changes in average temperature of the lake (measured in drill holes penetrating the base) with the change in altitude of stations near the collars of the holes. The mean coefficient of linear thermal expansion $(\alpha L)$ is given by the following formula (Skinner, 1966, p. 94):

$$
\alpha_{L}=\frac{1(\Delta L)}{L(\Delta T)}
$$

For the lava lake, $L$ equals the thickness of the lake, $\Delta L$ equals the change in thickness (that is, the change in relative altitude of the surface) for a given interval of time, and $\Delta T$ equals the change in average temperature during the same interval of time.

Relevant data are available for two surveying intervals at the main drilling site (DH12) and for one interval at station 4 , above the deepest part of the lake. Drill hole 12, which was equidistant from stations 6 and 26, pierced the base of the lake at a probable depth of $13.3 \pm 0.2 \mathrm{~m}$ (see table 4). Station 4 was $3.6 \mathrm{~m}$ east of drill hole 9 , which penetrated 1,840 lava below the lake at a probable depth of $14.9 \pm 0.1 \mathrm{~m}$. Changes in altitude and temperature at the two sites and the calculated linear coefficient of expansion are listed below.

\begin{tabular}{|c|c|c|c|}
\hline $\begin{array}{l}\text { Date, drill hole, and } \\
\text { survey stations }\end{array}$ & $\begin{array}{c}\text { Average change } \\
\text { in temperature } \\
\left({ }^{\circ} \mathrm{C}\right)\end{array}$ & $\begin{array}{l}\text { Change in } \\
\text { altitude ( } \mathrm{cm} \text { ) }\end{array}$ & $\begin{array}{c}\text { Coefficient of of } \\
\text { thermal expans } \\
\left(\times 10^{6 /} \mathrm{C} C\right)\end{array}$ \\
\hline \multicolumn{4}{|l|}{$\begin{array}{l}\text { January } 21 \text { to } \\
\text { August } 19,1965\end{array}$} \\
\hline $\begin{array}{l}\text { DH9 and Sta. } 4 \\
\text { DH12 and Sta. }\end{array}$ & -170 & -0.61 & 2.4 \\
\hline $\begin{array}{l}\quad 6 \text { and } 26 \\
\text { May } 27,1966 \text { to } \\
\text { August } 31,1967\end{array}$ & -155 & -.55 & 2.7 \\
\hline 6 and 26 & -295 & -1.28 & 3.3 \\
\hline
\end{tabular}

Taking into consideration the possible errors in determining changes in altitude, the effective bulk coefficient of linear thermal expansion is thus $3 \pm 1 \times 10^{-6} /$ ${ }^{\circ} \mathrm{C} .{ }^{4}$ This value is approximately one-half the values reported from measurements on similar rocks in the laboratory. Skinner (1966, p. 94) gives an average value of $5.4 \times 10^{-6} /{ }^{\circ} \mathrm{C}$ for 10 laboratory determinations of the coefficient of linear thermal expansion of basalt, diabase, and gabbro. Richter and Simmons (1974, table 2) give a measured value of $18.8 \times 10^{-6} /{ }^{\circ} \mathrm{C}$ and a calculated value of $19.0 \times 10^{-6} /{ }^{\circ} \mathrm{C}$ for the coefficient of volume thermal expansion of the chemically and mineralogically similar Frederick diabase; these values are equivalent to a coefficient of linear thermal expansion of $6.3 \times 10^{-6} /{ }^{\circ} \mathrm{C}$.

The difference between the value of the coefficient of thermal expansion determined in situ for Alae basalt and those determined in the laboratory on similar but coarser grained, more slowly cooled rocks can probably be attributed to the formation of microfractures across grains and along grain boundaries during cooling of the basalt as the result of stresses induced by differential thermal contraction of the constituent mineral grains. This conclusion is supported by the experimental work of Richter and Simmons (1974), which showed that high heating rates and heating to high temperatures $\left(>350^{\circ} \mathrm{C}\right)$ induce microfracturing that reduces the observed thermal expansion and results in a permanent lengthening of the samples. The two diabase samples studied by them lengthened 0.5 to $1.5 \times 10^{-3}$, after repeated heating to temperatures of $550-660^{\circ} \mathrm{C}$. Assuming that microfracturing reduced the effective bulk coefficient of linear thermal expansion in Alae lava lake by 50 percent, as indicated by comparison of the field and laboratory data, the expansion of the lake (actually, decreased subsidence) inferred to have taken place because of microfracturing during cooling from $980^{\circ} \mathrm{C}$ to $20^{\circ} \mathrm{C}$ was $3 \times 10^{-3}$, the same order of mag-

${ }^{4}$ Thermal modeling of temperatures within and below the lake (p. 45-47) suggests that changes in altitude caused by cooling and thermal contraction of the lake from January to August 1965 may have been reduced by about 10 percent because of heating and thermal expansion of lava beneath the lake. In contrast, changes in altitude from May 1966 to August 1967 may have been increased by about 10 percent because of cooling and thermal contraction of the underlying lava. Taking this effect into consideration would bring the calculated coefficients for the two periods into better agreement with the average value of $3 \times 10^{-6} /^{\circ} \mathrm{C}$. 
nitude as the strains measured in the laboratory.

The presence of relatively abundant microfractures in Alae basalt was inferred independently from the results of thermal conductivity measurements on samples from Alae lava lake and other Hawaiian lava flows. As reported by Robertson and Peck (1974) and discussed on p. 43 of this report, the effective conductivity of the samples studied was found to be 40 percent less than the measured or calculated inherent conductivity. On the basis of studies by Walsh and Decker (1966), the disparity was ascribed to microfractures, which were thought to form 0.5 percent or less of the solid portion of the samples. If the difference between the observed bulk coefficient of thermal expansion in Alae lava lake and the coefficient measured on similar rocks in the laboratory was caused entirely by microfracturing of Alae basalt, then microfracture porosity of the basalt was 0.3 percent.

When the calculated value of $3 \times 10^{-6} /{ }^{\circ} \mathrm{C}$ is used for the coefficient of linear thermal expansion, the contour maps of rates of subsidence can be used to estimate average rates of change of temperature in the lake below the surveying stations. The plot of figure 27 was prepared in this manner from figure $26 B$, and shows the estimated daily average decrease in temperature from January to August 1965. Excluding the cold margin of the lake, the calculated cooling rates during this period ranged from average values of about $0.7^{\circ} \mathrm{C} /$ day in the central part of the lake to a maximum of $2.7^{\circ} \mathrm{C} /$ day below station $1,30 \mathrm{~m}$ from the north margin. Cool-

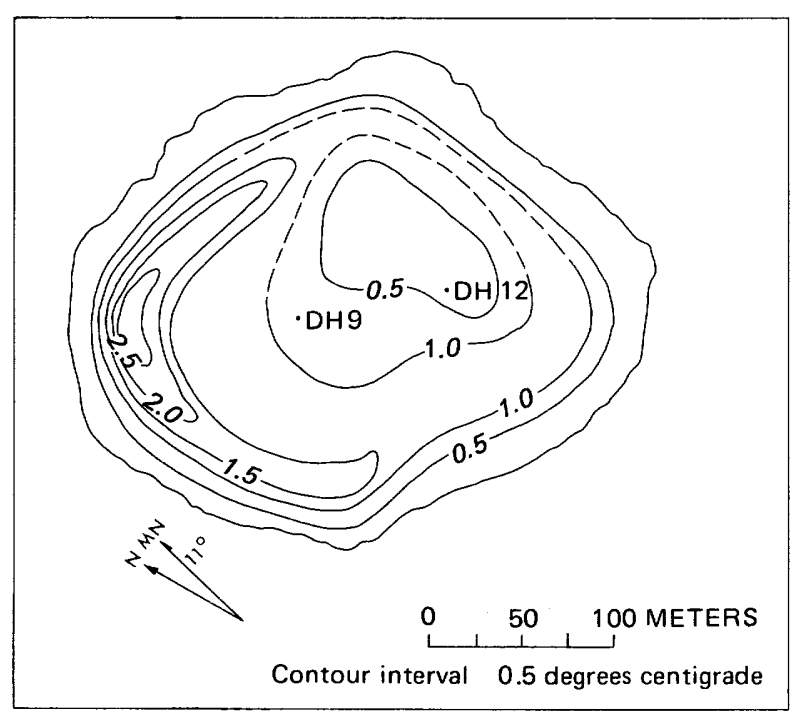

FIGURE 27.-Estimated daily average decrease in temperature in degrees centigrade in the lake from January to August 1965 , as determined from measured rates of subsidence during that period (fig. $26 B$ ) and the observed bulk coefficient of linear thermal expansion of $3 \times 10^{-6} /{ }^{\circ} \mathrm{C}$. The sites of drill holes 9 and 12 are marked. ing rates were highest in a ring (or annular volume) underlying the belt of maximum subsidence shown in figure $26 B$. This ring migrated inward as the lake cooled from September 1964 to August 1965, as shown by the relative positions of the axes of maximum subsidence in figure $26 \mathrm{D}$. Temperatures in the lake decreased sharply across the ring. Midway in the January to August 1965 interval, for example, the maximum temperature in drill hole $12,60 \mathrm{~m}$ inside the ring was $760^{\circ} \mathrm{C}$, whereas the maximum in drill hole 5 , $30 \mathrm{~m}$ outside the ring was only $95^{\circ} \mathrm{C}$. The average cooling rate of $0.7^{\circ} \mathrm{C} /$ day for the central part of the lake inferred by the subsidence rates is approximately the same as the value for this period of $0.9^{\circ} \mathrm{C} /$ day computed from the one-dimensional thermal model illustrated in figure 39. Because inferred cooling rates greatly exceeded this value in the ring of maximum subsidence and because the ring moved inward towards the lake in successive surveying periods, the ring is interpreted to be that part of the lake that was undergoing rapid cooling. Numerical analysis using two-dimensional models (p. 47) does not indicate the existence of such a zone of maximum cooling part way between the center and margin of the lake. Presumedly, the observed belt reflects some cooling process that was not incorporated in the model-possibly convective heat transfer by circulating rainwater in the cooler margin of the lake.

\section{CHANGES IN ALTITUDE OF THE SURFACE DLRING SOLIDIFICATION OF THE LAKE}

The most striking and consistent aspect of the contour maps showing rate of change of altitude during solidification of the lake (fig. 22) is the presence during each bimonthly period from September 1963 to September 1964 of a central area that had undergone uplift bordered by a marginal ring that had subsided. Subsidence of the entire lake surface after complete solidification suggests that before complete solidification the marginal ring of subsidence overlay the solidified outer part of the lake and that some process going on in the central lens of molten lava caused uplift of the overlying surface. This hypothesis can be tested by comparing temperatures in drill holes with rates of uplift and subsidence at the collars of the holes. Figure 28 shows rates of uplift and subsidence at stations on the lake compared with maximum temperatures in nearby drill holes. Each maximum temperature plotted is at the midpoint between the times of the corresponding level measurements. The temperatures were determined from plots of maximum temperature versus time (fig. 14); the plots were based on measurements in drill holes at the main drilling site and also in drill holes 5,6 , and 9 . The plot in figure 28 shows that uplift took place only over that part of the lake that 


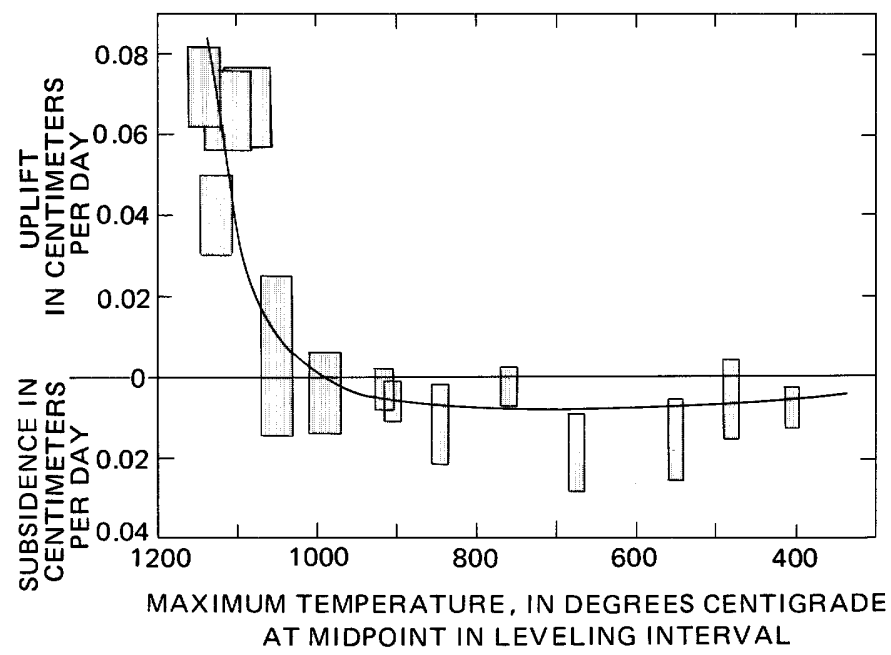

Figure 28.-Rates of uplift and subsidence of stations on the lake compared with maximum temperatures in the lake in nearby drill holes. Maximum temperatures are at the midpoints between times of level measurements. Width and length of bars indicate the uncertainty of the data.

had maximum temperatures of $1,000^{\circ} \pm 20^{\circ} \mathrm{C}$ or more, a value approximately the same as the solidus temperature of the basalt $\left(980^{\circ} \mathrm{C}\right)$ determined from petrographic study of drill core from the lake. Uplift, therefore, took place not only over the fluid core of the lake $\left(T>1,065^{\circ} \mathrm{C}\right)$ but also over the relatively rigid, but partly molten part still undergoing crystallization $\left(1,065^{\circ} \mathrm{C}>\mathrm{T}>980^{\circ}\right)$. Subsidence was limited to the completely crystallized but still cooling margin. The line between uplift and subsidence corresponded to the outer margin of the $1,000^{\circ}$ isothermal envelope, and the level measurements can be used to follow in detail the shrinkage of the lens of fluid and partly molten basalt as discussed on p. 39 and shown in figure 32 .

Changes with time in the rate of uplift of stations above the thick central part of the lake during solidification (figs. 22 and 23 ) were analyzed by comparing the rate of change of uplift at the main drilling site with rates of uplift calculated on the assumption that uplift was caused by vesiculation of the lava during solidification. The calculations, which are discussed below, show that the observed uplift can largely but not entirely be duplicated on the basis of this assumption.

The observed rates of uplift and subsidence at the main drilling site (DH1, 2, 3, 4, 7, 8, and 12) from August 30,1963, to September 24,1964, are shown as circles joined by solid line segments in figure 29. Rates are based on the average uplift and subsidence of stations 6 and 26, which span the site, and were plotted at the midpoint of each surveying interval. Points joined by dashed line segments show calculated rates of uplift for the same time intervals based on measured temperatures in the drill holes and computed temperatures

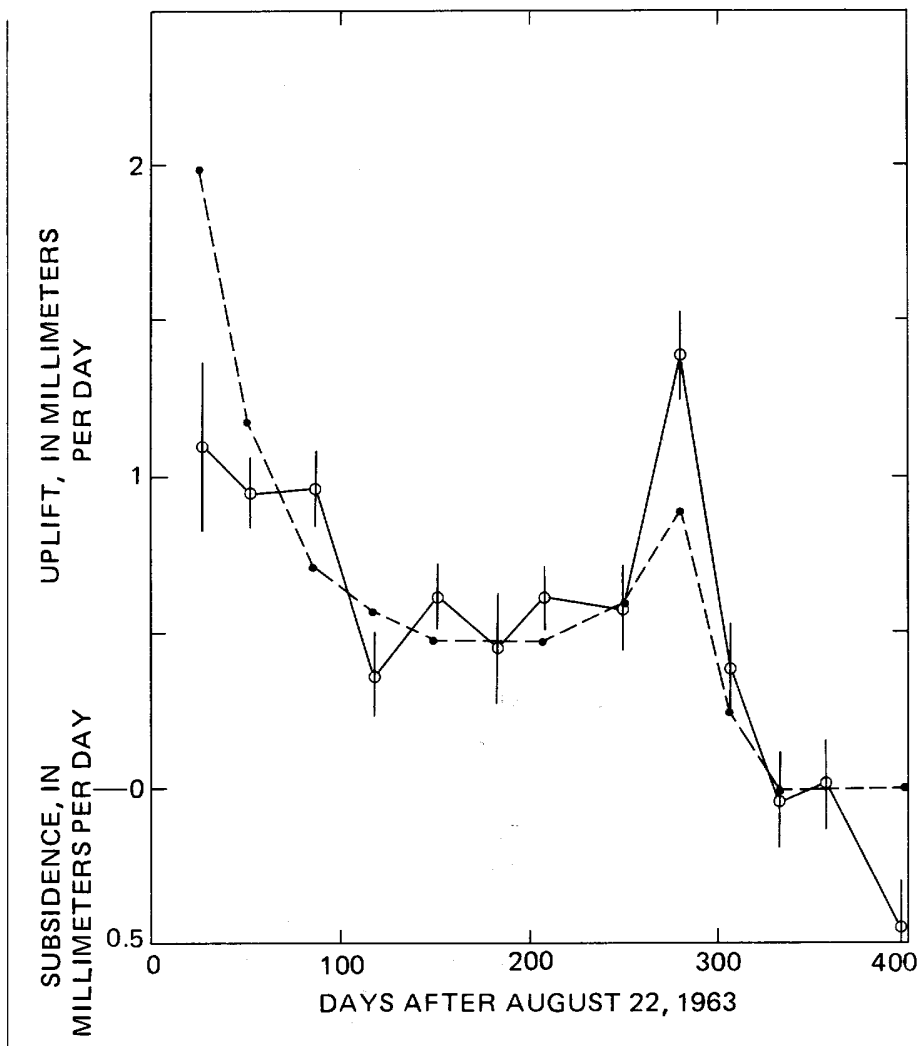

FIGURE 29.-Observed and calculated rates of uplift and subsidence at the main drilling site from August 30,1963, to September 24, 1964. Circles joined by solid lines are observed rates, plotted at the midpoints of the surveying intervals. Dots joined by dashed lines are calculated rates, as described in the text, p. 34,35 .

from a numerical model for a lake 47 feet $(14.3 \mathrm{~m})$ thick with a latent heat of $80 \mathrm{cal} / \mathrm{g}$ and a variable diffusivity, as discussed on p. 45. For each surveying interval, the uplift ( $\Delta L$ ) caused by formation of new crust was calculated by subtracting the subsidence due to crystallization of the new crust from the uplift caused by simultaneous vesiculation. In analogy with the relationship between linear and volume thermal expansion (Dane, 1941 , p. 29) the net uplift was taken to be one-third the net expansion during solidification. In order to simplify the calculations, subsidence caused by thermal contraction of cooling crust and fluid lava was neglected (the effect is approximately an order of magnitude less than the observed rates of uplift), and crystallization and vesiculation were assumed to take place at $1,065^{\circ} \mathrm{C}$. The calculations are based on the following factors: the observed increase in thickness of the upper crust $\left(\Delta D_{u}\right)$ during each leveling period (fig. 11); the computed increase in thickness of the lower crust $\left(\Delta D_{L}\right)$; the porosity $\left(\phi_{u}\right.$ and $\left.\phi_{L}\right)$ of solidified lava at those depths (table 5), as calculated from the measured bulk density of drill core; the density of $2.79 \mathrm{~g} / \mathrm{cc}$ for fluid lava in the lake $\left.\left(\rho_{m}\right)\right)$, as calculated from leveling 
and other data (p. 35-37); and the grain density $\left(\rho_{g}\right)$ of crystallized Alae basalt at $980^{\circ} \mathrm{C}$, as calculated from the grain density at room temperature $(3.01 \mathrm{~g} / \mathrm{cc})$ and the observed bulk coefficient of thermal expansion (p. 32). Expansion caused by vesiculation is proportional to the volume of vesicles and hence the porosity of newly formed crust, and equals $\phi \Delta D$. Contraction caused by crystallization is proportional to the difference between the density of fluid lava and the grain density of crystalline basalt, and equals

$$
\left(\frac{\rho_{m}-\rho_{g}}{\rho_{g}}\right) \Delta D \text {. }
$$

The formulation is as follows:

$$
\Delta L=1 / 3\left[\Delta D_{u} \phi_{\mathrm{u}}+\Delta D_{L} \phi L+\left(\Delta D_{\mathrm{u}}+\Delta D_{L}\right)\left(\frac{\rho_{m}-\rho_{g}}{\rho_{g}}\right)\right]
$$

Figure 29 shows a good correlation between observed and calculated rates from October 1963 (50 days) to July 1964 (300 days), indicating that uplift can indeed be attributed to vesiculation during solidification of new crust. The observed and calculated rates of uplift fell from an initial value of $1 \mathrm{~mm} /$ day at 50 days to a rather constant $0.5 \mathrm{~mm} /$ day after 100 days because of a progressive decrease in the vesicularity of new upper crust formed at greater depth and a decrease in the rate of solidification. The rates remained relatively constant until about 275 days when the margin of the lens of fluid lava passed beneath the site causing a short burst of rapid uplift. The rate thereafter rapidly decreased to zero as the entire lake beneath the site cooled to below the solidus. The divergence between calculated and observed rates of uplift at 275 days probably results from the simplifying assumption that all crystallization and vesiculation took place at $1,065^{\circ} \mathrm{C}$. The divergence during the first month after the eruption shows that uplift from vesiculation at the site during this period was offset by another processvery probably by lateral flowage of lava. Between August 30 and September 11, subsidence was measured at all but two of the nine stations measured (fig. $21 A$ ), and the pattern of uplift and subsidence suggests continued drainback of lava toward the vent. The changes measured between September 11 and 26 (fig. $21 B$ ), form a more complex pattern and may record not only uplift due to solidification of vesicular crust and changes due to lateral flowage, but also structural warping caused by horizontal expansion of the crust. Because of the correlation in time between a late stage, high rate of uplift at a site and the passage of the outer margin of the lens of fluid lava beneath the site, the leveling data of the full grid of stations can be used to determine the approximate outline of the lens of fluid lava during each successive leveling period. This approach was used in constructing figure 31 , which is presented later in this report. The results are not as accurate as the outline of the $1,000^{\circ}$ isothermal envelope (fig. 32), because the date of zero uplift at each station can be determined more accurately than the date of maximum uplift.

If uplift at each station of the lake was caused solely by expansion of fluid lava upon solidification, as suggested for the main drilling site after late September 1963 by the preceding analysis, then the ratio of lake thickness to total uplift at each station should be the same. Indeed, the total uplift at most stations after late September 1963 (fig. 24) was $1.4+0.2$ percent of the lake thickness. Exceptions include the stations near the lake margin, all of which had smaller proportionate uplifts or even net subsidence. Some of these stations overlay parts of the lake that had largely or completely solidified by the date of the first complete survey. For other stations, uplift was diminished by seepage of the underlying lava toward the vent and central parts of the lake during the first several leveling periods. Several stations nearer the center of the lake $(8,13$, and 29) have proportionate uplifts substantially higher than average (1.7-1.8 percent), and station 7 had proportionately less (1.0 percent). Stations with greater than average uplift are in broad areas part way between the center of the lake and the eastern and western margins. Inspection of plots of cumulative uplift for each station, such as that for station 29 in figure 23 , reveals that the higher or lower than average uplift at these stations took place between September 1963 and February 1964. The greater than average uplift may have been caused by the seepage of lava from the lake margins into the fluid core beneath the stations. However, another possible explanation for the differences in total uplift is suggested by the measured lateral expansion of the crust over the central part of the lake between September 1963 and July 1964 (fig. 25). The outward thrust of the central crust may have caused flexure of the crust between the expanding center of the lake and the solidified margin, forming anticlinal ridges and troughs. After April 1964, the greater thickness of crust over the central part of the lake and the greater width of solidified margin may have formed a container of solid basalt sufficiently rigid to prevent continued outward thrusting and the resulting warping.

\section{CALCULATION OF THE DENSITY OF FLUID LAVA IN THE LAKE}

Assuming that the average uplift of the surface above the lake after late September 1963 was caused solely by expansion of fluid lava during solidification, that is, that positive and negative variations in the uplift due to structural warping and lateral flow cancel 


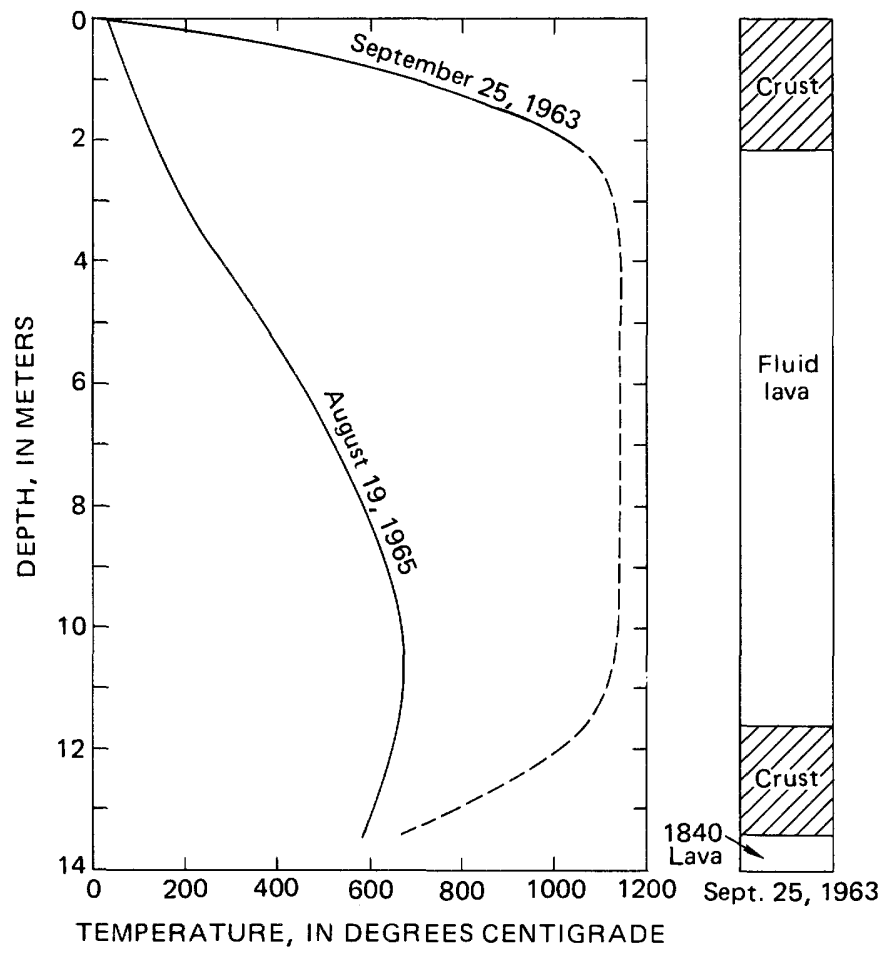

Figure 30.-Temperature profiles on September 25, 1963, and August 19,1965 , and a section through the lake on September 25, 1963. The 1963 profile was prepared from temperature measurements in drill hole 1 on September 24 and 26, 1963 (solid line), extrapolated to the base of the lake (dashed line) by computations based on thermal modeling. The 1965 profile was measured in drill hole 9.

out, the density of fluid lava in the lake in late September 1963 can be estimated from the measured changes in altitude of the surface during solidification. On September 25, 1963, the central part of the lake (using average values for all main stations on the grid except those very close to the margin-11, 23, 31, 32, and 34) consisted of $2.2 \mathrm{~m}$ of crust, $9.4 \mathrm{~m}$ of molten lava of average temperature, $1,130^{\circ} \mathrm{C}$, and $1.8 \mathrm{~m}$ of crust at the bottom of the lake. These figures are derived from the contour map of figure 1 and temperature profiles in drill hole 1 on September 24 and 26, 1963 (table 3), extrapolated to the base of the lake by computations based on thermal modeling similar to that illustrated in figure 39. The measured and extrapolated temperature profile is shown in figure 30 , together with a profile in drill hole 9 on August 19, 1965, that was also used in the calculation.

The calculations are based on the constancy of mass of the original lava and the derived solidified basalt. As mass equals density times volume, we can write the following equation:

$$
\rho_{f}=\frac{\rho_{s} V_{s}}{V_{f}}
$$

where $\rho$ equals density, $V$ equals volume, and subscripts $f$ and $s$ stand for fluid lava and solidified basalt. The density of the solidified basalt, $\rho_{s}$, is known from measurements of drill core. The volume ratio, $V_{s} / V_{f}$, can be calculated from the measured uplift of the lake surface and the average depth of the lake as determined by photogrammetry and vertical-angle surveys. In order to adjust for the effects of thermal contraction, temperature measurements in drill holes can be used to reduce the rock density measured at room temperature to its value at the solidus $\left(980^{\circ} \mathrm{C}\right)$ and to increase the observed uplift by the calculated thermal contraction of the lake during the period involved. In the calculations, we envisage a vertical segment of unit width through the lake that is representative of the central part of the lake.

The average density at $25^{\circ} \mathrm{C}$ of basalt solidified from the molten lava present on September 25, 1963-that is, basalt at depths in the lake between $2.2 \mathrm{~m}$ and $11.9 \mathrm{~m}$-is $2.665 \mathrm{~g} / \mathrm{cc}$ (table 5). The density at $980^{\circ} \mathrm{C}$ can be calculated using the coefficient of volume thermal expansion determined by the lake studies; $\alpha V$ equals $3 \alpha L$ (Dane, 1941, p. 29), and thus equals $9 \times$ $10^{-6 /}{ }^{\circ} \mathrm{C}$. The formulation is derived from the constancy of mass as follows:

$$
\begin{aligned}
& \rho_{980}=\frac{\rho_{25} V_{25}}{V_{980}} \\
& =\quad V_{25}^{\left.\frac{\rho_{25} V_{25}}{\left(1+\alpha_{V} \Delta\right.} T\right)} \\
& =\quad \frac{\rho_{25}}{1+\alpha_{V} \Delta T}
\end{aligned}
$$

where $\Delta T$ equals the change in temperature from $25^{\circ}$ to $980^{\circ} \mathrm{C}$.

The ratio $V_{s} / V_{f}$ (eq 1) of unit volumes of solidified basalt and fluid lava can be calculated from the change in thickness of the lake during solidification. In the lake, solidifying lava expanded in all three dimensions, as shown by changes in horizontal distance between stations on the lake surface (see section on "Changes in Horizontal Distance during Solidification"). Accordingly, the ratio of volumes, $V_{s} / V_{f}$, is equal to the cube of the ratio of thicknesses, $L_{s} / L_{f}$, of solidified and fluid lava. The formulation is as follows:

$$
\begin{aligned}
V_{s} / V_{f} & =\left(L_{s} / L_{f}\right)^{3} \\
& =\left[\frac{L_{f}+\Delta L_{u}+\Delta L_{c}}{L_{f}}\right]^{3}
\end{aligned}
$$

where $L_{f}$ equals $9.4 \mathrm{~m}$, the average thickness of fluid 
lava in the lake in late September, $1963 ; \Delta L_{u}$ equals 0.1475 , the average recorded uplift of 24 stations on the lake; and $\Delta L_{c}$ equals 0.0233 , the calculated decrease in altitude during this period caused by thermal contraction of the unit segment of solidified basalt and fluid lava. This decrease was calculated using the coefficient of linear thermal expansion $\left(3 \times 10^{-6}\right)$ and includes the following elements: $0.0018 \mathrm{~m}$ subsidence due to thermal contraction of $9.4 \mathrm{~m}$ of fluid lava as it cooled from $1,130^{\circ} \mathrm{C}$ to $1,065^{\circ} \mathrm{C} ; 0.0161 \mathrm{~m}$ subsidence from thermal contraction as it continued to cool from $1,065^{\circ} \mathrm{C}$ to the average value of $495^{\circ} \mathrm{C}$ on August 19, 1965; $0.0039 \mathrm{~m}$ of subsidence due to thermal contraction of the original $2.2 \mathrm{~m}$ of upper crust as it cooled an average of $590^{\circ} \mathrm{C}$ during this period; and $0.0015 \mathrm{~m}$ of subsidence due to the inferred $280^{\circ} \mathrm{C}$ of cooling of the original $1.8 \mathrm{~m}$ of lower crust.

When these values are used, the ratio $V_{s} / V_{f}$ is 1.0555 , and the calculated density of fluid lava is $2.79 \pm 0.03 \mathrm{~g} / \mathrm{cc}$. A fairly large uncertainty is indicated because of possible errors in several of the figures used in the calculation. The measured average density may be greater than the true density because of relatively poor core recovery from more vesicular layers in the crust. The measured average cumulative uplift may include an unknown contribution from structural warping or lateral flow. The value for the average depth of the lake may differ from the true value by as much as $0.3 \mathrm{~m}$ because of errors in the vertical angle measurements from the rim of the crater. The value of $2.79 \mathrm{~g} / \mathrm{cc}$ reported here is $0.01 \mathrm{~g} / \mathrm{cc}$ greater than the value reported earlier (Peck, 1969) from preliminary calculations.

The calculated value for the density of fluid lava can be compared with values for the density of basaltic melt derived from the measured densities of basaltic glass or calculated from a chemical analysis of the glass. Fluid lava at $1,130^{\circ} \mathrm{C}$ in Alae lava lake contained an estimated 15 percent crystals, consisting of 11 percent olivine and pyroxene and 4 percent plagioclase (Wright and Peck, 1978). The content of gas bubbles is not known but is inferred to be $1 / 2$ of 1 percent or less. Degassing of the initially oversaturated lava had largely finished by late September 1963 (p. 21-23 and figure 19). Vesiculation caused by crystallization over the temperature interval $1,140^{\circ}$ to $1,130^{\circ} \mathrm{C}$ should have yielded no more than $1 / 2$ of 1 percent gas bubbles, if vesiculation was proportional to crystallization, as illustrated in figure 20. As the mass of fluid lava $\left(m_{f}\right)$ equals the mass of the melt fraction $\left(m_{m}\right)$ plus crystals $\left(m_{c}\right)$ and gas bubbles $\left(m_{g}\right)$, the density of the melt fraction $\left(\rho_{m}\right)$ can be calculated from the densities of fluid lava $\left(\rho_{f}\right)$, crystals $\left(\rho_{c}\right)$, and gas bubbles $\left(\rho_{g}\right)$ from the following relationship:

$$
\begin{aligned}
m_{f} & =m_{m}+m_{c}+m_{g} \\
\rho_{f} V_{f} & =\rho_{m} V_{m}+\rho_{c} V_{c}+\rho_{g} V_{g} \\
\rho_{m} & =\frac{\rho_{f} V_{f}-\rho_{c} V_{c}-\rho_{g} V_{g}}{V_{m}}
\end{aligned}
$$

When one considers a unit volume of fluid lava, the volumes of melt, crystals, and gas bubbles $\left(V_{m}, V_{c}\right.$, and $V_{g}$ ) reduce to decimal proportions. The density of the exsolved gas is essentially zero, so that the term $\rho_{g} V_{g}$ can be dropped (the content of gas bubbles enters the calculations by reducing the decimal proportion of melt). The densities of the crystals at $1,130^{\circ} \mathrm{C}$ are 3.2 $\mathrm{g} / \mathrm{cc}$ for olivine and pyroxene and $2.65 \mathrm{~g} / \mathrm{cc}$ for plagioclase, judging from their densities at room temperature as determined by mineral separations (Wright and Peck, 1978) and published coefficients of volumetric thermal expansion (Skinner, 1966, p. 87). When one assumes a zero content of gas bubbles, the calculated density of the melt fraction is $2.74 \mathrm{~g} / \mathrm{cc}$. With $1 / 2$ of 1 percent gas bubbles the calculated density of melt is $2.76 \mathrm{~g} / \mathrm{cc}$. The measured density at room temperature of glass separated from two samples of pumice formed during the Alae eruption at $1,140^{\circ} \mathrm{C}$ and $1,160^{\circ} \mathrm{C}$ is 2.76 $\mathrm{g} / \mathrm{cc}$ (Wright and Peck, 1978). Vesicle-and crystal-free glass from differentiated melt collected at a temperature of $1,100^{\circ} \mathrm{C}$ from drill hole $69-1$ in Makaopuhi lava lake has a density at room temperature of 2.78 g/cc. (T. L. Wright and N. L. Hickling, oral commun., 1975). If these are reduced to the values at $1,130^{\circ} \mathrm{C}$ using the coefficient of volumetric thermal expansion of $9 \times 10^{-6 /{ }^{\circ}} \mathrm{C}$, the densities of the melt fraction are 2.73 and $2.75 \mathrm{~g} / \mathrm{cc}$; these densities are in good agreement with the density of the melt fraction calculated on the assumption that the proportion of exsolved gas is negligible. The density of glass from Alae pumice can also be calculated from a chemical analysis of the pumice using the method of Bottinga and Weill (1970), in which density is calculated from the partial molar volumes of the oxide components. Molar volumes at $1,130^{\circ} \mathrm{C}$ were determined by linear extrapolations of the values listed for greater temperatures $(1,250$ $1,600^{\circ} \mathrm{C}$, in Bottinga and Weill, 1970 , table 5 and p. 175-176). The density for the melt at $1,130^{\circ} \mathrm{C}$ calculated by this method is $2.704 \mathrm{~g} / \mathrm{cc}$, about 1 percent less than the values derived from the density measurements in the laboratory or calculated from the lavalake data.

\section{THE PATTERN OF COOLING IN THREE DIMENSIONS}

Some aspects of the three-dimensional pattern of solidification and further cooling of Alae lava lake were revealed by repeated temperature measurements in drill holes in different parts of the lake and by repeated 


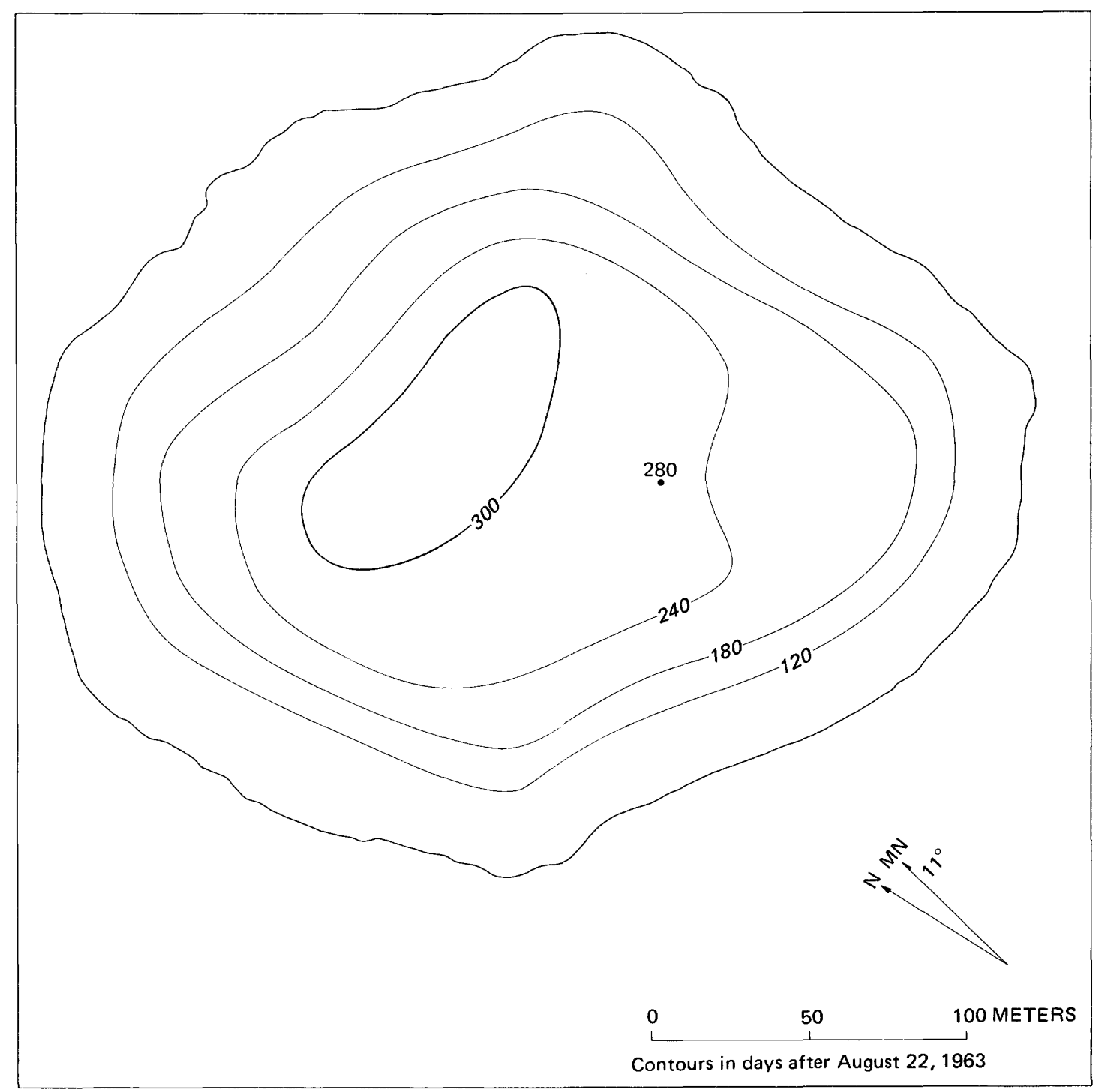

FIGURE 31.-Approximate position of the outer margins of the $1,080^{\circ} \mathrm{C}$ isothermal surface in the lake as a function of time in days after August 22, 1963. The date when the margin passed beneath drill holes 3, 4, and 8 (marked by a dot in fig. 31) was calculated by extrapolation of a plot of maximum temperatures versus time (fig. 14), and the position of the margin was estimated elsewhere by determining the time interval during which each surveying station underwent a late-stage, high-rate of uplift (fig. 23 and table 6).

surveys of the altitude of the grid of stations on the lake surface. In the following section, the position with time of the outer margin of the $1,080^{\circ} \mathrm{C}$ isothermal surface (approximately the fluid-crust interface) and the $1,000^{\circ}$ isothermal surface (approximately the solidus) are shown in plan and those of the $1,000^{\circ} \mathrm{C}$ and $700^{\circ} \mathrm{C}$ surfaces are shown in cross section. The measured and inferred positions of the isothermal surfaces agree closely with the positions computed on the basis of two-dimensional numerical models, which are illustrated in figure 40 .

The approximate position in plan of the outer margin of the $1,080^{\circ} \mathrm{C}$ isothermal surface is shown as a func- tion of days after August 22, 1963, in figure 31; the position is based on sparse temperature data from drill holes and on the surveying interval or intervals when each surveying station underwent a late stage, high rate of uplift. As discussed on p. 35, this phase of uplift at a station records the migration through the lake beneath the station of the outer margin of the lens of fluid lava and reflects the high rate of crystallization and vesiculation between $1,080^{\circ} \mathrm{C}$ and $1,050^{\circ} \mathrm{C}$. Figure 31 clearly shows the effect on the rate of solidification of the thinning of the lake over preeruption ridges beneath the north and southeast parts of the lake, as well as the rather rapid solidification of the lens of fluid lava 


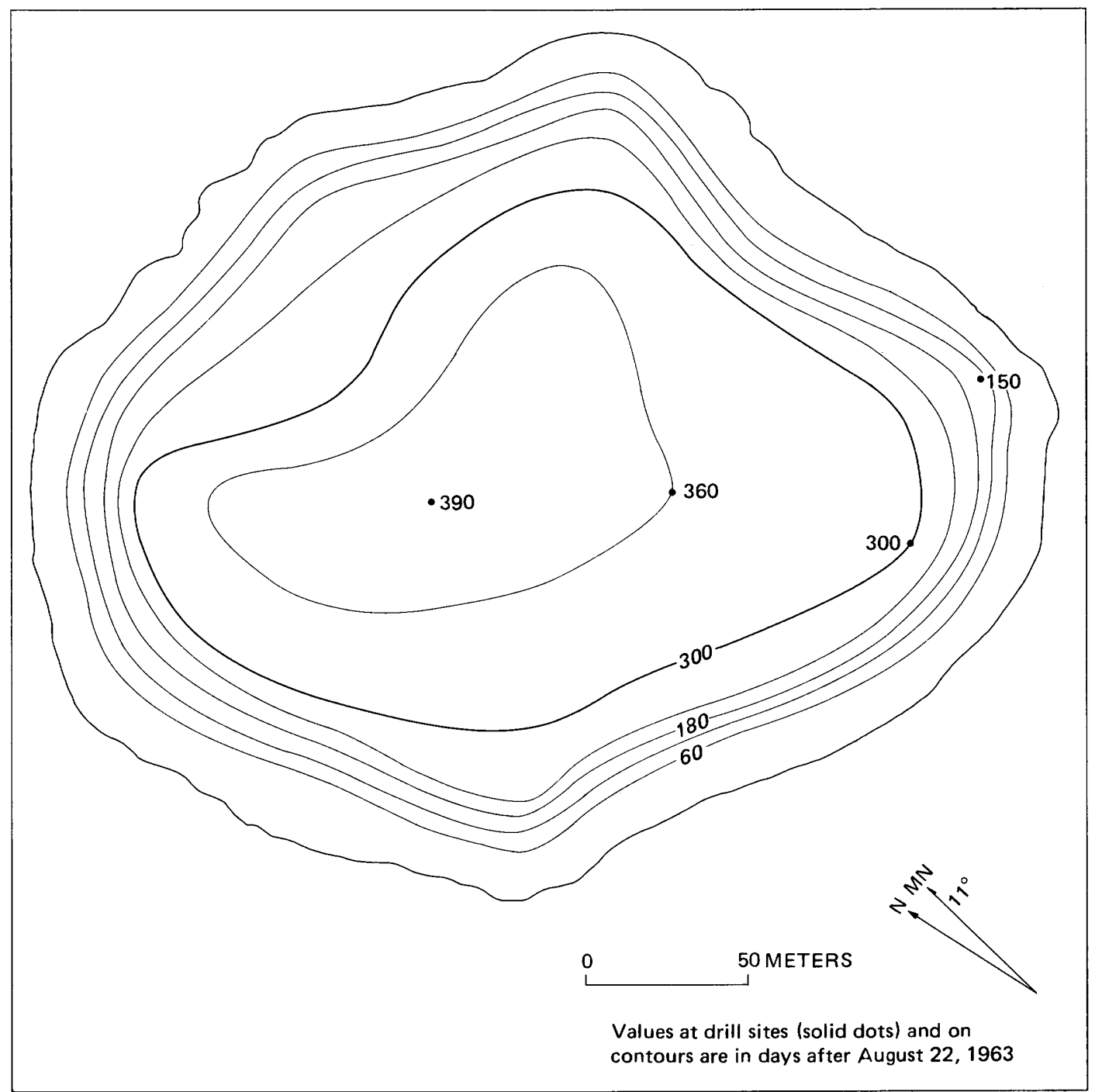

Figure 32.-Outer margins of the $1,000^{\circ} \mathrm{C}$ isothermal surface (approximately the solidus) in Alae lava lake as a function of days after August 22,1963. The maximum lateral extent of the surface on different dates is based on precise level measurements of stations on the surface of the lake (fig. 22 and table 6) and on temperature measurements in drill holes (solid dots) that penetrated to the depths of the maximum temperature at the time of complete solidification.

after 250 days. The outer margin of the $1,080^{\circ} \mathrm{C}$ isothermal surface after 300 days outlines fairly closely that part of the lake that was $14 \mathrm{~m}$ or more thick.

The position of the $1,000^{\circ} \mathrm{C}$ isothermal surface, approximately the solidus, is shown in plan and longitudinal section in figures 32 and 33 . The location of the surface was determined from interpolation and extrapolation of temperature data from drill holes $5,6,8$, 9 , and 12 and from the time at which each surveying station started to subside. The change from uplift to subsidence at a station reflected the completion of crystallization and vesiculation in the lake beneath that station (p. 33, 34 and fig. 28). Figure 32 shows, as does figure 31 , the effect of prelake highs beneath the north and southeast parts of the lake and the rapid completion of crystallization during the final 100 days. The position of the $1,000^{\circ} \mathrm{C}$ isothermal surface is known more precisely than the $1,080^{\circ} \mathrm{C}$ surface because more temperature data are available and because the time of the beginning of subsidence at each station can be accurately determined by plotting rates of change in altitude versus time for each station and interpolating the intersection with the zero rate axis. Figure 33 shows the position of the isothermal surface in sections, the lower with the vertical scale equal to the horizontal scale and the upper with a $10 \times$-vertical exaggeration. In the lower part of the lake, the position 

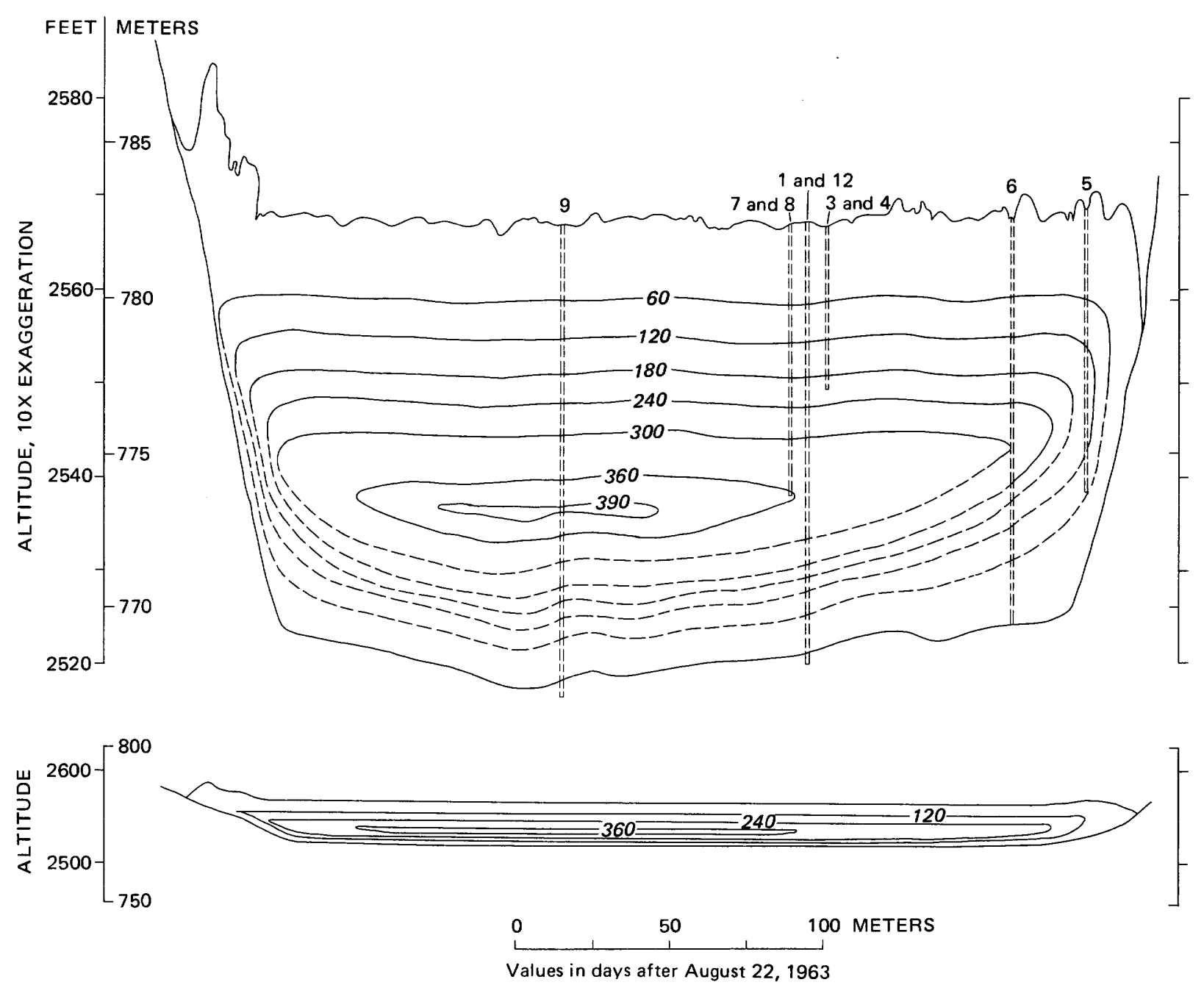

FIGURE 33.-Longitudinal cross section of Alae lava lake showing the positions of the $1,000^{\circ} \mathrm{C}$ isothermal surface as a function of days after August 22, 1963. Isotherms dashed were extrapolated. Upper section, 10× vertical exaggeration; lower section, horizontal and vertical scales are equal. Numbered vertical lines are projected drill holes.

of the isothermal surface (dashed) is largely inferred. Near the end of crystallization, the lens of partly molten lava is at a depth 60 percent of the distance from the upper surface and within the thickest part of the lake. Figures 32 and 33 show that final crystallization took place more rapidly in the thinner southeastern part of the lake than in the thicker, spatter-covered northwestern part; the figures are in good agreement with the computed position of the $1,000^{\circ} \mathrm{C}$ isotherm in a generalized radial section of the lake after 300 days (fig. 40).

The depth of the $700^{\circ} \mathrm{C}$ isothermal surface in both the upper and lower parts of the lake (fig. 34) is known from several drill holes in both the marginal (DH5 and 6) and central (DH1, 3, 4, 7, 8, 9, and 12) parts of the lake. The position through time of the outer margin, however, is rather poorly known at distances from drill holes, because the data from repeated surveys of the altitude of stations on the lake surface are of little help in determining its location. The only relevant data from the altitude surveys is the position of the axis of maximum subsidence after solidification of the lake; the position puts an outer bound on the margin of the surface during two surveying periods. As in figure 33, the section shows the effect of lake thickness on the position of the isotherms-the last part to cool to $700^{\circ} \mathrm{C}$ was in the thickest part of the lake and at a depth 75 percent of the lake thickness below the surface. Computed positions of the $700^{\circ}$ isotherm at 300 and 600 days (fig. 40) are in close agreement.

\section{THERMAL PROPERTIES OF ALAE BASALT}

Several thermal properties of Alae basalt were measured in the laboratory or were calculated from laboratory data on the constituent minerals. 


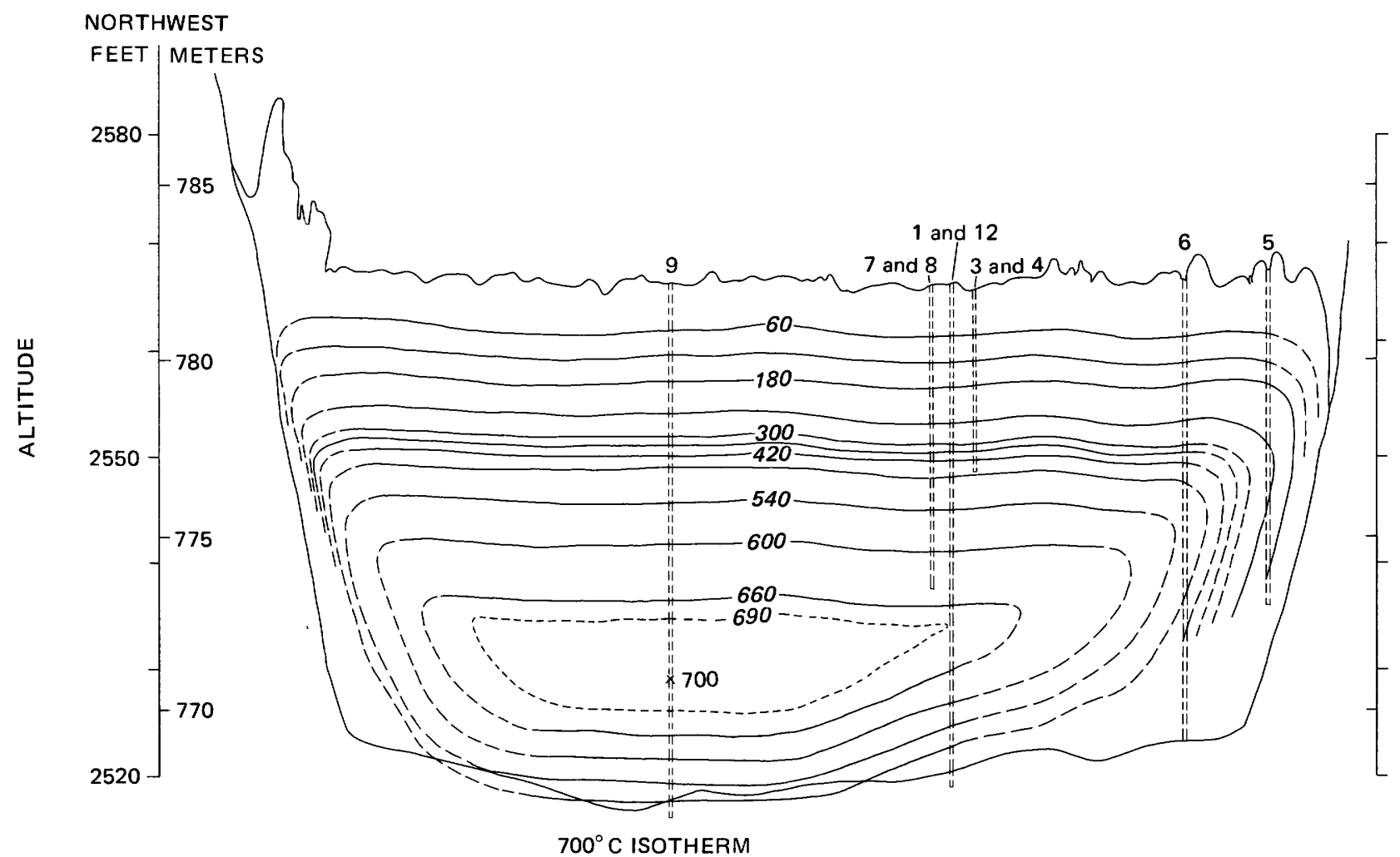

$700^{\circ} \mathrm{C}$ ISOTHERM

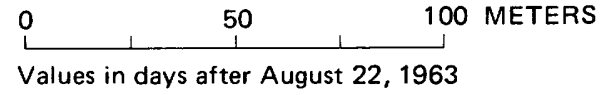

FIgURE 34.-Longitudinal cross section of Alae lava lake showing the position of the $700^{\circ} \mathrm{C}$ isothermal surface as a function of days after August 22, 1963 (10× vertical exaggeration). Isotherms dashed were extrapolated. The position was determined from temperature profiles in drill holes, which are shown projected into the line of section as numbered vertical dashed lines.

The thermal conductivity at ambient temperatures of Alae basalt can be determined from the graphs and formulation of Robertson and Peck (1974, figs. 7 and 8, eq 12), derived from detailed conductivity measurements at $35^{\circ} \mathrm{C}$ of vesicular basalt from Hawaii. The 61 samples studied included 4 from the crust of Alae lava lake (Robertson and Peck, 1974 or 1969 , nos. 613,618 , 619 , and 620 ). Conductivity was found to vary with porosity, olivine content, and the nature of the pore fluid (air or water). The conductivity of basalt samples which have the same pore fluid and similar olivine contents varies inversely with porosity, forming a linear plot against $(1-\text { porosity })^{2}$. The conductivity $(K)$ in air of Alae basalts can be calculated from the following equation (Robertson and Peck, 1974, eq 12, p. 4884):

$$
\sqrt{ } K=a+b\left(\gamma \sqrt{ } K_{s}+\phi \sqrt{ } K_{a}\right)
$$

where $a$ and $b$ are experimentally determined constants, $\gamma=$ solidity (that is, 1 - porosity), $\phi=$ porosity, $K_{s}=$ conductivity of fully solid basalt, and $K_{a}=$ conductivity of air. When one uses the experimentally determined values of $6.1 \times 10^{-3} \mathrm{cal} / \mathrm{cm} \sec { }^{\circ} \mathrm{C}$ for $K_{s}$,
$0.063 \times 10^{-3} \mathrm{cal} / \mathrm{cm} \mathrm{sec}{ }^{\circ} \mathrm{C}$ for $K_{a}, 0.2$ for $a$, and 0.7 for $b$, the equation reduces to:

$$
K=(1.929-1.554 \phi)^{2} \text {. }
$$

The conductivity of Alae and other Hawaiian basalts which have $0-5$ percent olivine, as calculated from this equation, is shown as a function of porosity in figure 35 . Alae basalt with 11 percent porosity, which forms the bulk of the lake, has a conductivity of $3.09 \times 10^{-3}$ $\mathrm{cal} / \mathrm{cm} \mathrm{sec}{ }^{\circ} \mathrm{C}$, but the conductivity values for more vesicular basalt decrease to $1.71 \times 10^{-3} \mathrm{cal} / \mathrm{cm} \mathrm{sec}{ }^{\circ} \mathrm{C}$ for the basalt with 40 percent porosity that forms the thin surficial crust of the lake.

An appreciable increase in conductivity with temperature for solidified, vesicular Alae basalt is shown by laboratory measurements reported in this section and also by the results of thermal modeling discussed later (p. 45-47). This variation differs from that of previously published laboratory studies on the variation with temperature of the conductivity of basalt, apparently because of the effect of abundant vesicles. As summarized by Nafe and Drake (1968) and Robertson 


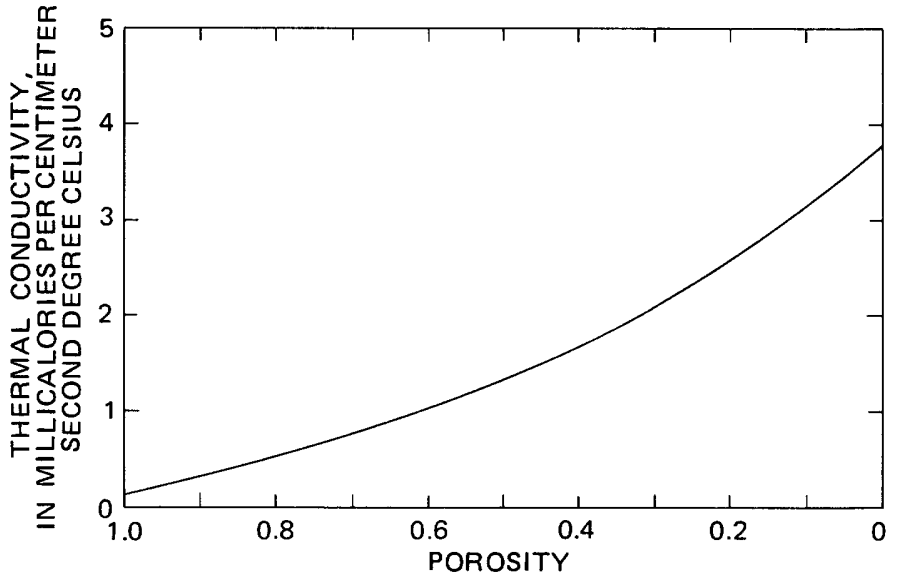

FIgURE 35.-Thermal conductivity at $35^{\circ} \mathrm{C}$ of air-saturated Alae basalt. Curve calculated using the formulation and experimentally determined constants of Robertson and Peck (1974, p. 4884), as discussed in the text.

(unpub. data, 1976), most laboratory measurements of the variation with temperature of the conductivity of basalt indicate that conductivity values do not vary greatly with increasing temperature, although on the average they show a slight increase. Apparently the decrease in conductivity with increasing temperature of pyroxene and olivine is approximately counterbalanced by the increase in conductivity of plagioclase (Birch and Clark, 1940). Murase and McBirney (1973), however, found that the conductivities of Columbia River basalt and alkali olivine basalt from the Galapagos decrease about 50 percent from room temperature to $1,100^{\circ} \mathrm{C}$. At greater temperatures conductivities increased sharply because of increased photon conductivity (Murase and McBirney, 1973, p. 3584).

The studies summarized above were made on samples which have little or no porosity. In order to determine the effects of abundant vesicles on the variation of conductivity with temperature, Kaoru Kawada of the Earthquake Research Institute, Tokyo University, kindly measured the conductivity of four samples from Alae crater (written commun., 1966). Two of the samples (A-5-1 and A-11-1) were coarsely vesicular drill core from near the surface of the 1963 lava lake, one sample (DPH-28) was a coarsely vesicular hand sample from an open joint crack near the main drilling site, and the fourth sample (AM-51) was a finely vesicular hand sample from the petrographically similar prehistoric Alae lava lake, collected on the cliff face of the mezzanine $9.8 \mathrm{~m}$ below the surface of the lake. Conductivities were measured on cylindrical samples $2.5 \mathrm{~cm}$ in diameter and $5.0 \mathrm{~cm}$ in length in a furnace under controlled temperature. The temperature was increased in small increments by means of a heating filament inserted in a $0.25 \mathrm{~cm}$ diameter hole along the axis of each sample, and temperatures were recorded by thermocouples in two $0.18 \mathrm{~cm}$ diameter holes drilled 0.3 and $1.2 \mathrm{~cm}$ from the axis, half the length of each sample parallel to the axis and in the same plane. The experimental apparatus and techniques are described by Kawada (1966).

The results are listed in table 7 and are plotted in figure 36 as ratios of the measured conductivities at high temperatures to the conductivities at room temperature. For three of the samples, conductivities increased nearly linearly with increasing temperature to the highest temperatures at which conductivities were measured $\left(673^{\circ}-950^{\circ} \mathrm{C}\right)$. The greatest rate of increase of conductivity with temperature, 0.09 percent $/{ }^{\circ} \mathrm{C}$, was shown by the highly vesicular samples A-5-1 and A-11-1, which had bulk porosities of 28 and 25 percent respectively. A smaller increase, 0.03 percent $/{ }^{\circ} \mathrm{C}$, was shown by the denser sample AM-51, which had a porosity of 7 percent. The fourth sample, DPH-28, which had a porosity of 24 percent, showed a nearly

TABLE 7.-Thermal conductivity of four samples of basalt from Alae crater as a function of temperature [Data from K. Kawada (written commun., 1966]

\begin{tabular}{|c|c|c|c|c|c|c|c|c|}
\hline & $\begin{array}{c}\text { Temperature } \\
\left({ }^{\circ} \mathrm{C}\right)\end{array}$ & $\begin{array}{c}\text { A-5-1 } 1^{1} \\
\text { Conductivity } \\
\left.\text { (cal/cm sec }{ }^{\circ} \mathrm{C}\right)\end{array}$ & $\begin{array}{c}\text { Temperature } \\
\left({ }^{\circ} \mathrm{C}\right)\end{array}$ & $\begin{array}{c}\text { A-11-12 } \\
\text { Conductivity } \\
\left(\text { cal/cm sec }{ }^{\circ} \mathrm{C}\right)\end{array}$ & $\underset{\left({ }^{\circ} \mathrm{C}\right)}{\text { Temperature }}$ & $\begin{array}{c}\text { AM-513 } \\
\text { Conductivity } \\
\left(\mathrm{cal} / \mathrm{cm} \mathrm{sec}{ }^{\circ} \mathrm{C}\right)\end{array}$ & $\begin{array}{c}\text { Temperature } \\
\left({ }^{\circ} \mathrm{C}\right)\end{array}$ & $\begin{array}{c}\text { DPH-284 } \\
\text { Conductivity } \\
\text { (cal/cm sec }{ }^{\circ} \mathrm{C} \text { ) }\end{array}$ \\
\hline 28 & ---------------- & $1.19 \times 10^{-3}$ & 46 & $2.21 \times 10^{-3}$ & 32 & $2.07 \times 10^{-3}$ & 40 & $2.86 \times 10^{-3}$ \\
\hline 70 & - - - & $1.27 \times 10^{-3}$ & 94 & $2.36 \times 10^{-3}$ & 54 & $2.06 \times 10^{-3}$ & 74 & $2.77 \times 10^{-3}$ \\
\hline 73 & $--1--1-1-1$ & $1.23 \times 10^{-3}$ & 194 & $2.53 \times 10^{-3}$ & 62 & $2.05 \times 10^{-3}$ & 149 & $2.70 \times 10^{-3}$ \\
\hline 128 & - - - - & $1.28 \times 10^{-3}$ & 430 & $3.01 \times 10^{-3}$ & 123 & $1.99 \times 10^{-3}$ & 185 & $2.36 \times 10^{-3}$ \\
\hline 139 & ------- - & $1.27 \times 10^{-3}$ & 551 & $3.27 \times 10^{-3}$ & 274 & $2.17 \times 10^{-3}$ & 268 & $2.23 \times 10^{-3}$ \\
\hline 216 & - & $1.52 \times 10^{-3}$ & 699 & $3.64 \times 10^{-3}$ & 363 & $2.24 \times 10^{-3}$ & 313 & $2.40 \times 10^{-5}$ \\
\hline 306 & 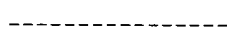 & $1.66 \times 10^{-3}$ & 804 & $3.83 \times 10^{-3}$ & 450 & $2.33 \times 10^{-3}$ & 370 & $2.21 \times 10^{-3}$ \\
\hline 433 & - & $1.70 \times 10^{-3}$ & 946 & $4.03 \times 10^{-3}$ & 451 & $2.25 \times 10^{-3}$ & 495 & $2.11 \times 10^{-3}$ \\
\hline 527 & -------------- & $1.72 \times 10^{-3}$ & - & $-\ldots---$ & 528 & $2.27 \times 10^{-3}$ & -- & 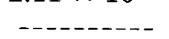 \\
\hline 653 & --------------- & $1.93 \times 10^{-3}$ & -- & - - - - - - - & 673 & $2.49 \times 10^{-3}$ & - & -- - - - - - - \\
\hline 722 & $-------1----1--$ & $2.00 \times 10^{-3}$ & - & $\ldots \ldots \ldots$ & -- & --------- & -. & -- - - - - \\
\hline 839 & $---------\div------$ & $2.12 \times 10^{-3}$ & -- & - - - - - - & -- & - - - - - - & -- & - - - - \\
\hline 950 & $------1---1-1+-$ & $2.24 \times 10^{-3}$ & - & $-\ldots--\ldots$ & - & -------- & - & $--1-\ldots-1$ \\
\hline
\end{tabular}

${ }^{1}$ Drill core collected at a depth of $0-0.1 \mathrm{~m}$ in drill hole 5 in the 1963 Alae lava lake. Measured bulk density, $2.16 \mathrm{~g} / \mathrm{cm}^{3}$. Calculated porosity, 0.28 .

${ }^{2}$ Drill core collected at a depth of $0-0.15 \mathrm{~m}$ in drill hole 11 in the 1963 Alae lava lake. Measured bulk density, $2.25 \mathrm{~g} / \mathrm{cm}^{3}$. Calculated porosity, 0.25 .

${ }_{4}^{3}$ Hand sample collected from the cliff face of the prehistoric lava lake $16 \mathrm{~m}$ below the mezzanine of Alae crater. Measured bulk density, $2.80 \mathrm{~g} / \mathrm{cm}^{3}$. Calculated porosity, 0.07 .

${ }^{4}$ Hand sample collected from an open joint crack in the 1963 Alae lava lake near drill hole 1 . Measured bulk density, $2.28 \mathrm{~g} / \mathrm{cm}^{3}$. Calculated porosity, 0.24 . 


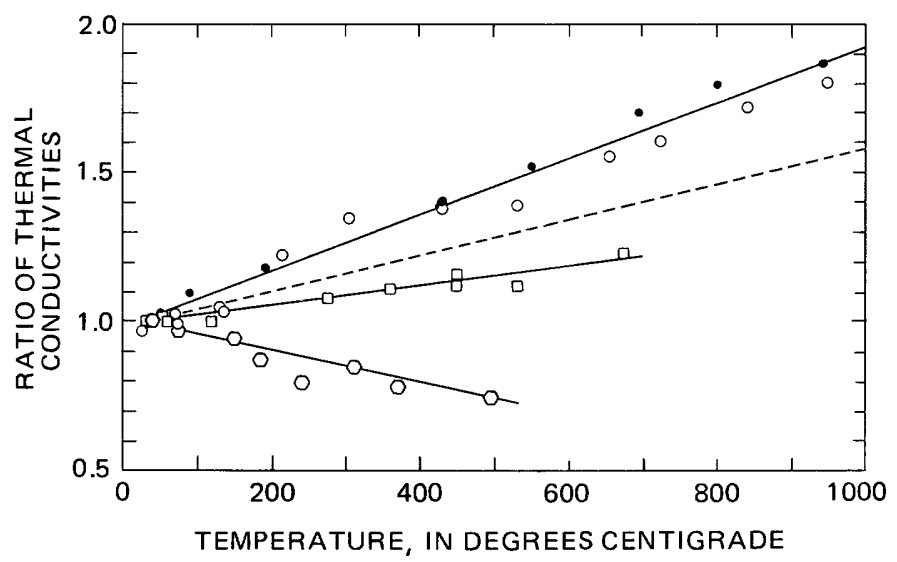

FIGURE 36.-The ratio of conductivity at high temperature to conductivity at room temperature of four samples of basalt from Alae crater. Data from K. Kawada (written commun., 1966). Samples A-5-1 (circles), A-11-1 (dots), and DPH-28 (hexagons) are from the August 1963 lava lake; sample AM-51 (squares) was collected from a prehistoric lake exposed in the wall of the crater. The dashed line indicates ratios calculated on the basis of an increase in conductivity of 0.06 percent $/{ }^{\circ} \mathrm{C}$, as deduced from thermal modeling (p. 45).

linear decrease in conductivity, 0.05 percent $/{ }^{\circ} \mathrm{C}$, to $495^{\circ} \mathrm{C}$, the highest temperature measured. Kawada suggested that the decrease in conductivity of this sample may record the temperature effect for dense, nonporous basalt. Although the sample was highly vesicular, the vesicles were large compared with the sample size, and none may have been situated along the axial plane containing the heating element and sensing thermocouples. Low porosity in the axial plane is suggested by the relatively high conductivity of 2.86 $\times 10^{-3} \mathrm{cal} / \mathrm{cm} \mathrm{sec}{ }^{\circ} \mathrm{C}$ measured at room temperature. A disparity between bulk porosity of the samples and the porosity in the axial planes is also suggested for two other samples, A-5-1 and AM-51, by a comparison of the relatively low conductivities measured at room temperature in these experiments with the measurements of Robertson and Peck (1974) and the resulting formulation on page 41 . The marked increase in conductivity with temperature of three of the samples was confirmed by H. R. Shaw (written commun., 1975) by laboratory measurements of the diffusivity of vesicular basalt from Makaopuhi laval lake as a function of temperature, but is in contrast with the small changes with temperature found by other workers on nonporous samples. The difference may be due to radiative heat transfer across the vesicles, convective heat transfer by gases in the vesicles, or progressive closing of microfractures as the result of thermal expansion of the samples during heating.

In situ thermal conductivity in the Alae lava lake may have been greater at higher temperatures because of the effect of an additional process, a decrease in con- ductivity with falling temperature in the cooling lava caused by successive formation of microfractures resulting from thermally induced stresses. The presence of relatively abundant ( 0.3 percent) microfractures in the crust of the lake is suggested by the disparity between the measured bulk coefficient of thermal expansion in the lake and coefficients determined in the laboratory on basalt and diabase of similar composition (p. 32, 33). Microfractures across grains and along grain boundaries are also evident in thin sections under the microscope. The effect of microfractures on rock conductivity has been demonstrated in the laboratory by measurements of conductivity with increasing pressure (Walsh and Decker, 1966) and was suggested as a possible factor in the conductivity of vesicular Hawaiian basalt by Naoyuki Fujii and George C. Kennedy (oral commun., 1974) after a review of the conductivity data. Robertson and Peck (1974) found that the intrinsic conductivity of nonporous basalt, as measured on finely crushed samples or calculated from mineral conductivities and the mode, was 40 percent greater than the effective conductivity determined from laboratory measurements on discs. They suggested that the difference was due to microvesicles and microfractures formed during initial cooling of the parent lava.

The thermal modeling of the temperature data in Alae lava lake described in the section "Thermal Modeling" also indicates that the conductivity of solidified basalt in the lake increased with temperature. The results do not define the form of the relationship or the relative importance of radiative heat transfer, convective heat transfer, or microfracturing. The results do indicate that conductivity $(K)$ at a given temperature $\left(T\right.$, in $\left.{ }^{\circ} \mathrm{C}\right)$ can be related approximately to the conductivity at room temperature $\left(K_{R T}\right)$ for temperatures less than $1,000^{\circ} \mathrm{C}$ by the linear relationship $K \times$ $K_{R T}(1+0.000 \beta T)$, where $\beta$ equals $0.0006 \pm 0.0001$. Values calculated by this function are represented by the dashed line in figure 36 . The conductivity of Alae basalt at temperatures of more than $1,000^{\circ} \mathrm{C}$ is not known. Thermal modeling using greatly different values for the conductivity of solid and molten basalt resulted in very small differences in temperatures, less than the accuracy of the field measurements. Laboratory studies by Murase and McBirney (1973) suggest that the conductivity of basalt at temperatures between the solidus and the liquidus is less than the conductivity at lower temperatures.

The heat capacity of Alae basalt at six temperatures from $300^{\circ}$ to $1,400^{\circ} \mathrm{K}$ was calculated by R. A. Robie (written commun., 1964) using the modal mineral composition (p. 3) and experimentally determined values of the specific heats of the minerals later published by Robie and Waldbaum (1968). The results are 
TABLE 8.—Specific heats of minerals and calculated heat capacity of Alae basalt [Data from R. A. Robie (written commun., 1964)]

\begin{tabular}{|c|c|c|c|c|c|c|c|c|c|}
\hline \multicolumn{2}{|c|}{$\begin{array}{l}\text { Temperature } \\
{ }^{\circ} K\end{array}$} & \multicolumn{7}{|c|}{ Specific heat cal $/ \mathrm{g}^{\circ}$} & \multirow{2}{*}{$\begin{array}{c}\begin{array}{c}\text { Heat } \\
\text { capacity }\end{array} \\
\text { Basalt }\end{array}$} \\
\hline & & Fayalite & Fosterite & Diopside & Albite & Anorthite & Magnetite & Ilmenite & \\
\hline 300 & - & 0.1564 & 0.2011 & 0.1742 & 0.1876 & 0.1789 & 0.1569 & 0.1572 & 0.1783 \\
\hline 500 & - & .1890 & .2535 & .2331 & .2389 & .2319 & .1890 & .1854 & .2318 \\
\hline 800 & 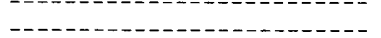 & .2108 & .2822 & .2617 & .2688 & .2614 & .2610 & .2017 & .2608 \\
\hline 1000 & 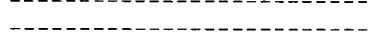 & .2218 & .2949 & .2731 & .2826 & .2747 & .2072 & .2092 & .2724 \\
\hline 1200 & 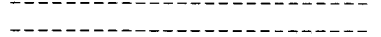 & .2320 & .3060 & .2825 & .3029 & .2864 & .2072 & .2165 & .2849 \\
\hline 1400 & - & .2418 & .3165 & .2911 & .3066 & .2974 & .2072 & .2223 & .2927 \\
\hline
\end{tabular}

tabulated in table 8 . Values range from $0.1783 \mathrm{cal} / \mathrm{g}{ }^{\circ} \mathrm{C}$ at $300^{\circ} \mathrm{K}$ to $0.2927 \mathrm{cal} / \mathrm{g}{ }^{\circ} \mathrm{C}$ at $1,400^{\circ} \mathrm{K}$. A smooth curve for heat capacity $(c)$ as a function of temperature (fig. 37) was constructed on the basis of the calculated heat capacities and fitted to the following function of temperature ( $T$ in Kelvins) by R. A. Robie (written commun., 1975):

$$
c=0.2356+4.3635 \times 10^{-5} T-\frac{6.3440 \times 10^{3}}{T^{2}}
$$

Thermal diffusivity in the cooling Alae lava lake undoubtedly varied with time and depth. Diffusivity $(D)$ is related to conductivity $(K)$, density $(\rho)$, and heat capacity $(c)$ by the following relationship:

$$
D=K / \rho c
$$

Conductivity varies with vesicularity as well as tem-

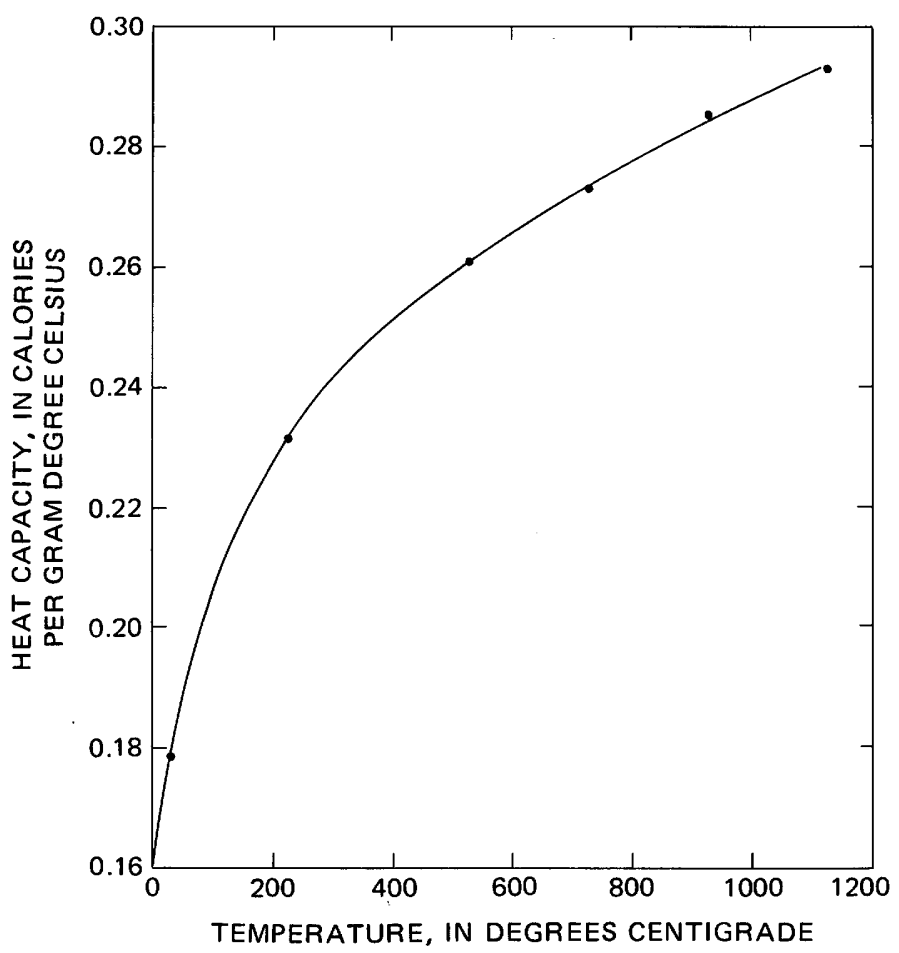

Figure 37.-Calculated heat capacity of Alae basalt as a function of temperature. perature, as discussed above, and hence with depth in the lake and probably with time at a given depth during solidification. The same is true of density. Both the heat capacity and conductivity vary with temperature, hence they vary also with time and depth. Increased conductivity with decreased porosity and increased temperature, however, is at least partly offset by the increased density of less porous basalt and the increased heat capacity at greater temperature. Changes in diffusivity of solidified basalt with time and depth in the lava lake are illustrated in figure 38; the figure shows computed diffusivities for solidified basalt on 2 days during solidification (Sept. 6 and Dec. 30, 1963) and 3 days thereafter. Diffusivity values were computed using a numerical formulation (p. 45-47) for a lake 49 feet $(14.9 \mathrm{~m})$ thick having a latent heat of 80 $\mathrm{cal} / \mathrm{g}$, a conductivity that increased 0.06 percent $/{ }^{\circ} \mathrm{C}$ and varied with porosity as described on page 41 , a variable heat capacity described on pages 43,44 and a density structure in the lake as tabulated in table 5. A lowconductivity vesicular cell at shallow depth was not included. Calculated diffusivities increased downward in the upper 3-5 $\mathrm{m}$ of the crust because of the increase in density and temperature with depth. On December 30 , 1963, for example, the calculated diffusivity increased from $0.0049 \mathrm{~cm}^{2} / \mathrm{sec}$ at $0.15 \mathrm{~m}$ depth to 0.0064 $\mathrm{cm}^{2} / \mathrm{sec}$ at a depth of $3.8 \mathrm{~m}$. The average diffusivity of the upper crust (average of values at $0.3 \mathrm{~m}$ intervals) increased from $0.0055 \mathrm{~cm}^{2} / \mathrm{sec}$ on September 6, 1963, to 0.0058 on September 3,1964 . The computed average diffusivity of the lake after complete crystallization in late September 1964 decreased from a maximum value of $0.0060 \mathrm{~cm}^{2} / \mathrm{sec}$ on December 8,1964 , to $0.0058 \mathrm{~cm}^{2} /$ sec in August 1965 and May 1966, but thereafter increased to 0.0060 on August 31,1967 , as temperatures continued to fall.

The latent heat of Alae basalt can be deduced from numerical analysis of the thermal data (p. 45, Peck and others, 1977), and can also be calculated using estimated and experimentally determined heats of fusion of the component minerals. Unfortunately, the reliability of the calculated value is limited because of uncertainty in the values of heats of fusion of the major 


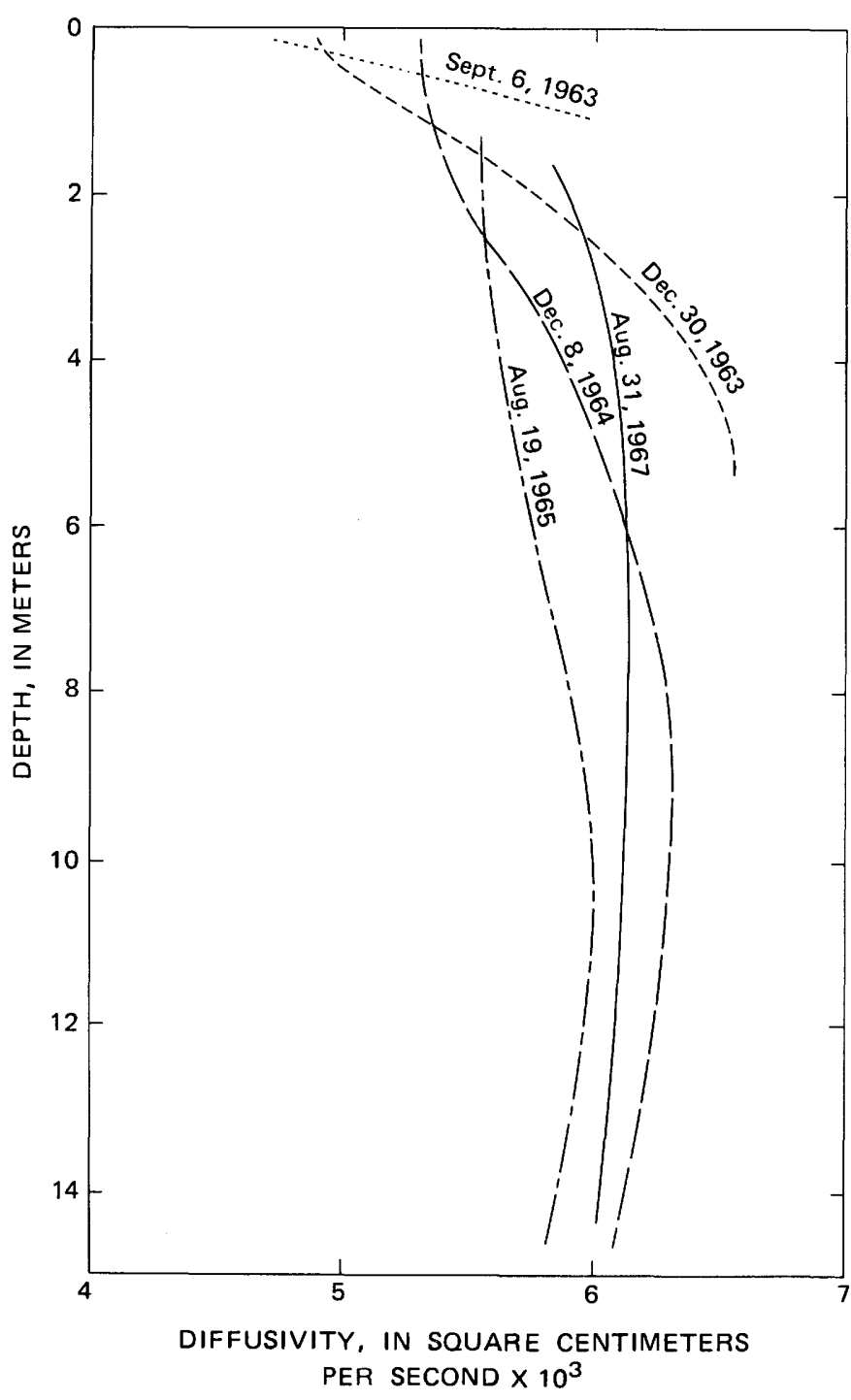

FIGURE 38.-Calculated diffusivity of solidified Alae basalt $\left(<1,000^{\circ} \mathrm{C}\right)$ as a function of depth and time. Curves are based on computed values at $0.3 \mathrm{~m}$ intervals, as described in the text.

constituents augite and labradorite. Calculations were made using the modal data on page 3 and the normative composition of the 6.75 percent residual silicic glass (Wright and Weiblan, 1968). Values for heats of fusion were taken from Robie and Waldbaum (1968) and Bradley (1962), and were supplemented by a value of $22.4 \mathrm{kcal} / \mathrm{gfwt}$ for augite Wo. ${ }_{4} \mathrm{En} ._{4} \mathrm{Fs}_{._{2}}$ estimated by D. R. Wones (written commun., 1964, 1975) and two rather different estimates for anorthite-29.4 kcal/ gfwt (Wones) and $18.7 \mathrm{kcal} / \mathrm{gfwt}$ (Yoder, 1975). When these values are used, the calculated latent heat of completely (100 percent) crystalline Alae basalt would be $94 \mathrm{cal} / \mathrm{g}$ or $85 \mathrm{cal} / \mathrm{g}$, depending on the value used for anorthite. The calculated latent heat that would be released during crystallization in the lake, however, is substantially less, 77 or $67 \mathrm{cal} / \mathrm{g}$, because of the crystallization prior to the eruption of 13 percent olivine, pyroxene, and plagioclase, and the retention of nearly 7 percent silicic glassy residuum at the end of crystallization. The calculated values are in good agreement with the value of $80 \pm 10 \mathrm{cal} / \mathrm{g}$ deduced from numerical analysis of the temperature data (p. 45).

\section{THERMAL MODELING}

Temperature profiles in Alae lava lake were analyzed (Peck, Hamilton, and Shaw, 1977) using the one- and two-dimensional computer programs for cooling lava lakes devised by Shaw, Hamilton, and Peck (1977). The effort was an extension of a preliminary analysis conducted with J. C. Jaeger (written commun., 1967) that was summarized by Peck (1974). Computed temperature profiles were compared with representative profiles measured in the central part of the lake on 12 separate days from September 6, 1963, to August 31, 1967. The effect of rainfall on temperatures in the lake was computed by withdrawing 620 calories from the $100^{\circ} \mathrm{C}$ isotherm for each centimeter of measured rainfall. The latent heat was distributed in three temperature intervals in accordance with modal data on crystal abundance within partly molten lava near the base of the crust-that is, 30 percent from $1,140^{\circ}$ to $1,080^{\circ} \mathrm{C}, 41$ percent from $1,080^{\circ}$ to $1,050^{\circ} \mathrm{C}$, and 29 percent from $1,050^{\circ}$ to $980^{\circ} \mathrm{C}$. The upper surface was held at $70^{\circ} \mathrm{C}$ for the first 5 months and at $40^{\circ} \mathrm{C}$ thereafter, and temperatures in the lake were reduced by conductive cooling to a surface at a temperature of $20^{\circ} \mathrm{C}$ at a depth 100 feet $(30.5 \mathrm{~m})$ below the bottom of the lake. A cell length of 1 foot $(0.3 \mathrm{~m})$ and a time interval of $3.237 \times 10^{4}$ seconds 0.385 day) were selected for the computations.

During the initial runs using one-dimensional models, thermal and physical properties of basalt in the lake were assumed to be constant, and a lake thickness of 48 feet $(14.6 \mathrm{~m})$ was chosen to simulate the deeper, central part of the lake. Ten measured profiles during the first 2 years of cooling were reproduced with average deviations of $20^{\circ} \mathrm{C}$ using a constant diffusivity of $0.006 \mathrm{~cm}^{2} / \mathrm{sec}$ and a latent heat of $90 \mathrm{cal} / \mathrm{g}$. A better match, particularly of temperature profiles in the upper crust during initial cooling and at the base of the lake after complete solidification, was obtained using numerical models incorporating variable thermal and physical properties, as well as slightly different values for lake thickness and latent heat. The following modifications were made to the initial model.

1. A variable diffusivity was included by assigning values for density and conductivity at room temperature to each 1 -foot $(0.3 \mathrm{~m})$ cell in the lake; this density was based on the measured density (table 5) and the relationship between conductivity and porosity de- 


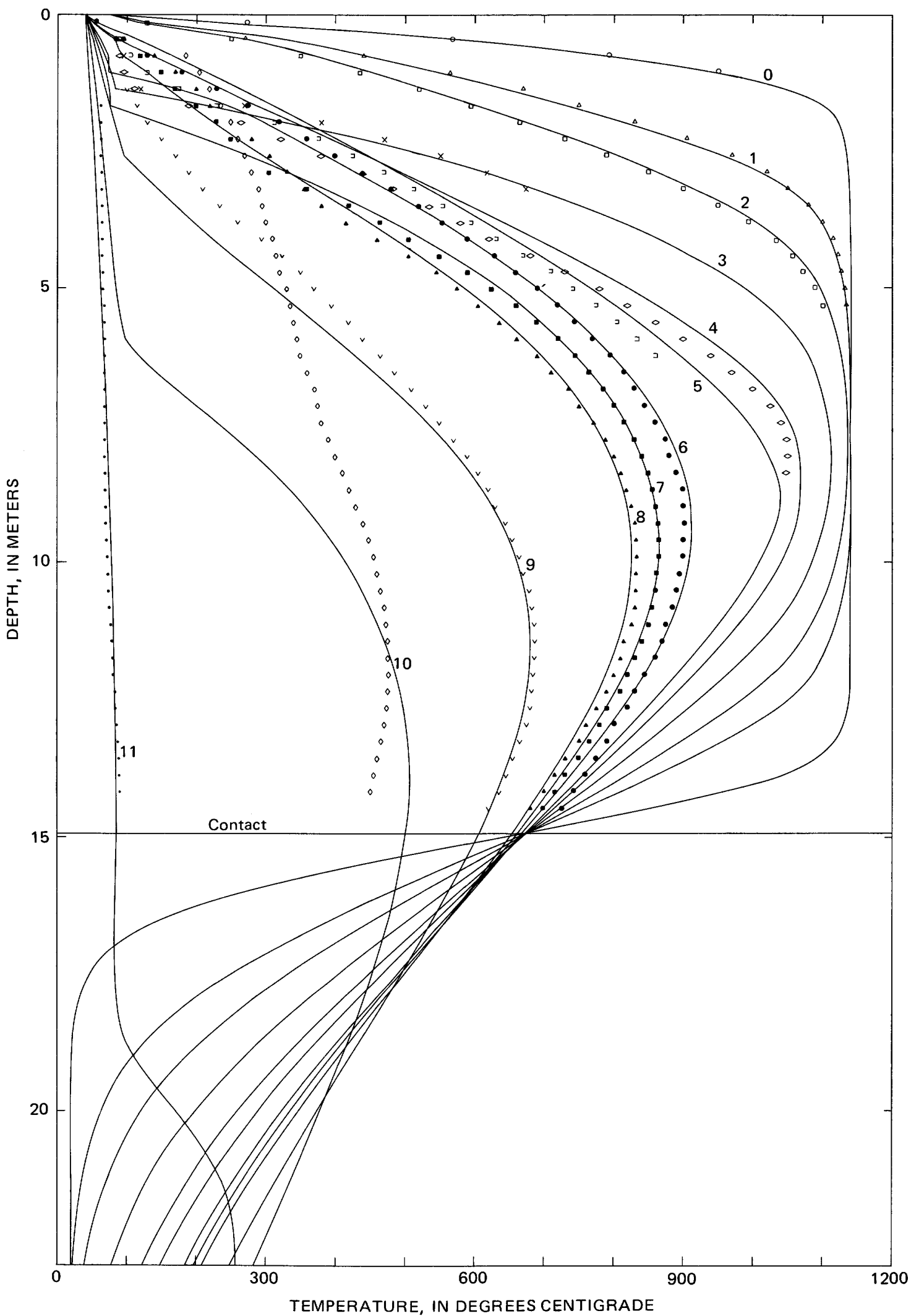

Figure 39. - Computed (solid) and observed (symbols) temperature profiles in Alae lava lake. Temperature data are marked in table 3 and the dates indicated in figure 10. The dates for the profiles and the drill holes in which the temperatures were measured are as follows: 0, Sept. 6, 1963, DH 1; 1, Nov. 5 and 8, 1963, DH 3; 2, Dec. 30, 1963, DH 4; 3, Mar. 24, 1964, DH 4; 4, July 2, 1964, DH 8; 5, Sept. 3, 1964, DH 8; 6, Dec. 8, 1964, DH 9; 7, Jan. 21, 1965, DH 9; 8, Mar. 2, 1965, DH 9; 9, Aug. 19, 1965, DH 9; 10, May 27, 1966, DH 12; 11, Aug. 31, 1967, DH 12. 
scribed on p. 41. Heat capacity, conductivity, and diffusivity were calculated for each cell by an iterative process, using the relationship between heat capacity and temperature given on page 43 , and a linear increase of 0.06 percent $/{ }^{\circ} \mathrm{C}$ of conductivity with increasing temperature.

2. Heat loss by rainfall was computed using the measured density structure of the lake.

3. The lake thickness was increased to 49 feet $(14.9 \mathrm{~m})$, a better approximation of the deepest part of the lake near drill hole 9 , and the latent heat for the basalt was decreased accordingly to $80 \mathrm{cal} / \mathrm{g}$.

4. Low-conductivity and density values were assigned to one of the cells to simulate the highly vesicular and cavernous zone found at shallow depth in the lake.

The computed profiles for a lake 49 feet $(14.9 \mathrm{~m})$ thick and measured profiles in Alae lava lake are shown in figure 39. The measured profiles are based on temperatures measured at depth intervals of $0.3 \mathrm{~m}$ or less for the first four profiles and $0.9 \mathrm{~m}$ or less for the last eight. Temperatures read from smoothed plots of the profiles are shown by symbols at 0.3 intervals on the figure, and the dates of the profiles are indicated in figure 10. The last two profiles (10 and 11), which were measured in drill hole 12 on May 27, 1966, and August 31, 1967, are not strictly comparable with the computed profiles or with the other measured profiles. The lake was an estimated $1 \frac{1}{2} \mathrm{~m}$ shallower at this site, and the upper part of the hole was heated by gases rising along a fracture intersected in the drilling. However, this was the only drill hole open through the lake during the last 2 years. Using the numerical model described above and illustrated in figure 39 , average deviations (at $0.3 \mathrm{~m}$ intervals) between computed and measured temperatures for the 10 representative profiles during the first 2 years are less than $2^{\circ} \mathrm{C}$. Measured temperatures for the first three profiles are matched with average deviations of one-half ${ }^{\circ} \mathrm{C}$. Measured and computed maximum temperatures after solidification (profiles 6 to 9) and basal contact temperatures for profiles 7 to 9 are matched within $2^{\circ} \mathrm{C}$. The computed contact temperature for profile 6 is $27^{\circ} \mathrm{C}$ less than observed; this difference may reflect errors in the measurement of the values for depths or temperatures near the base of the lake for that profile. The poorest match of computed and measured temperatures is for profile 4 , for which computed temperatures on the average are $55^{\circ} \mathrm{C}$ greater than observed. The profile was measured in drill hole 8 only 2 weeks after the hole was drilled, and temperatures in the upper part of the hole were probably still strongly depressed because of the coolant water used in the drilling. Computed and measured temperatures August 31, 1967 (profile 11), 4 years after formation of the lake, agree with an average deviation of $0.5^{\circ} \mathrm{C}$, and the computed and measured temperatures (at the base of the lake) differ by only $1^{\circ} \mathrm{C}$. The value of the observed maximum of $86^{\circ} \mathrm{C}$ suggests that the lake cooled to less than $100^{\circ} \mathrm{C}$ several months before the date of the measurement. In the computer model the lake cooled to $100^{\circ} \mathrm{C}$ in mid-April 1967, 41/2 months before the final temperature measurements. Computed temperatures in the lake using a "no-rain" model are as much as $366^{\circ} \mathrm{C}$ greater than observed on August 31,1967, and the lake takes a total of 19.5 years to cool to $100^{\circ} \mathrm{C}$.

Cooling at the margins of Alae lava lake was analyzed using a two-dimensional numerical model formulated by Shaw, Hamilton, and Peck (1977). The results are presented by Peck, Hamilton, and Shaw (1977) and summarized below. A generalized radial section of the southern quarter of the lake was divided into cells $15 \mathrm{~m}$ long and $1.5 \mathrm{~m}$ thick (Shaw and others, 1977, fig. 6), and the model cooled in 150 time steps of $8.318 \times 10^{5} \mathrm{sec}$ (9.63 days) duration. A constant value of diffusivity of $0.006 \mathrm{~cm}^{2} / \mathrm{sec}$ and a latent heat of $80 \mathrm{cal} / \mathrm{g}$ were used in the calculations, and heat loss from rain was taken into account using a constant value for the average density of the lake. The results are illustrated in figure 9 of Peck, Hamilton, and Shaw (1977), which shows the positions of several isotherms (including the $1,080^{\circ}, 1,000^{\circ}$, and $700^{\circ}$ ) after 300 days, and in figure 40 , which shows the positions of the $1,000^{\circ}$ isotherm after 120,240 , and 360 days. The computed temperature distribution in cross section, which is in close agreement with temperatures measured in drill holes and inferred from level surveys (figs 31-34), indicates that temperatures in the central part of the lake were not influenced by cooling at the margins. Throughout the first year, temperatures in the computer model were decreased more than $1^{\circ} \mathrm{C}$ only in the outer $15 \mathrm{~m}$ of the lake, and in the fourth year only in the outer $45 \mathrm{~m}$. The variation of 90 days in the dates of complete solidification in the central part of the lake (figs. 32 and 33) can be attributed to lateral variations of about $2 \mathrm{~m}$ in the depth of the lake. Heat transfer to the margins, however, may have been a more significant factor in the cooling of Alae lava lake than in the model because of factors that were not incorporated in the model. This conclusion is suggested by the existence of a belt of maximum subsidence in the lake detected by repeated level surveys during the first year after solidification (fig. 26). The belt, which presumedly represents the part of the lake undergoing the most rapid cooling and thermal contraction, does not manifest itself in the two-dimension thermal model. Possi- 


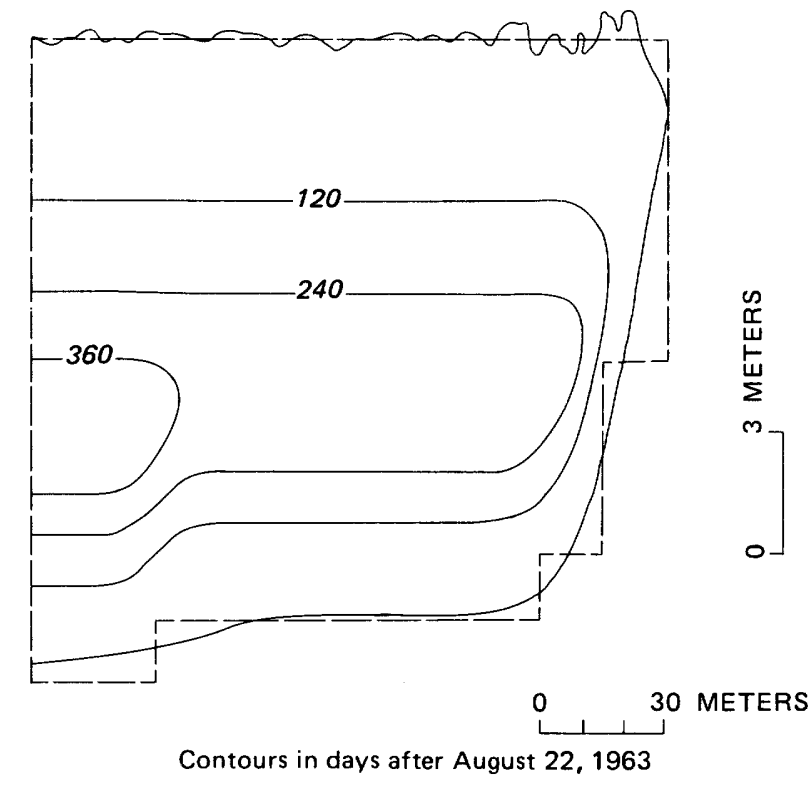

Figure 40.-Computed position of the $1,000^{\circ} \mathrm{C}$ isotherm in a generalized radial section of Alae lava lake after 120, 240, and 360 days. Computations based on a two-dimensional model having a latent heat of $80 \mathrm{cal} / \mathrm{g}$ and a constant diffusivity of $0.006 \mathrm{~cm}^{2} / \mathrm{sec}$. Solid boundary shows the margins of the lake in a generalized section based on measured surface profiles and the topographic map of the crater (fig. 1 ). Dashed boundary shows the margin of cells in the simplified model used in the numerical calculations (Shaw and others, 1977, fig. 6B).

bly, cooling in the lake itself was accelerated because of shallow circulation in the margin of the lake of water, less than $100^{\circ} \mathrm{C}$, derived from rain that fell on the lake margin, bordering talus, and crater walls.

\section{CONCLUSIONS}

The 15-m-thick Alae lava lake solidified in $10 \frac{1}{2}$ months and cooled to less than $100^{\circ} \mathrm{C} 3$ years later. Study of the lake, combined with study of Makaopuhi lava lake (Wright and others, 1968; Wright and Okamura, 1977) and Kilauea Iki lava lake (Richter and Moore, 1966) provide a unique body of data on the cooling and crystallization of Kilauean tholeiite. Alae was the smallest of the three lakes, cooled in the least time, and showed the simplest pattern of solidification and cooling. Major conclusions of this study are as follows:

1. Solidification of Alae lava lake took place by the slow increase in thickness of upper and lower crusts with time (fig. 10). Growth of the upper crust during the first 3 months was linear with respect to the square root of time; the thickness (in meters) was equal to $0.00132 \sqrt{t}-0.18$, where $t$ equals time in seconds after the eruption.

2. Crystallization of tholeiitic basalt in the lake took place over a temperature interval of $160^{\circ} \mathrm{C}$ from the emplacement temperature of $1,140^{\circ} \mathrm{C}$ to the solidus temperature of $980^{\circ} \mathrm{C}$. The interface between fluid lava and solid crust was at $1,065^{\circ} \mathrm{C}$. Measured temperatures at the base of the lake were as much as $700 \pm 10^{\circ} \mathrm{C}, 60$ percent of the initial temperature of the lake (table 4).

3 . The lava vesiculated as it cooled and crystallized because of the exsolution of gases, raising the upper surface of the lake (fig. 22) and forming porous basalt that decreased in porosity (and increased in density) downward from the surface (fig. 16, table 5). Initially, gas was exsolved because of supersaturation of the newly erupted lava; later vesiculation was caused by crystallization and resulted in minute, angular pores (fig. 18). Repeated leveling surveys combined with temperature measurements in the drill holes permit delineation of the approximate outline in plan of the lens of fluid lava (fig. 31) and the outline in plan and section of the fluid lava and partly molten crust (figs. 32, 33). Comparison of these figures with computer runs based on twodimensional thermal modeling (fig. 40) indicates that solidification rates in the central part of the lake were not affected by cooling at the lake margin.

4. The lake continued to cool for 3 years after solidification. Thermal contraction of the cooling basalt caused subsidence of the lake surface (fig. 26). The bulk linear coefficient of thermal expansion $\left(3 \pm 1 \times 10^{-6} /{ }^{\circ} \mathrm{C}\right)$ determined by the lake's studies is markedly less than values measured in the laboratory on similar rocks, presumedly because of microfracturing caused by differential thermal contraction.

5. Measured temperatures in the cooling lake can be matched within the limits of error of the measurements and of the lateral variability of temperature in the lake by computations based on numerical models (fig. 39), indicating that the

- lake cooled largely by conductive heat transfer. Vaporization of the abundant rainfall, however, strongly affected temperatures in the upper crust during solidification and throughout the lake thereafter. Near joint cracks, temperatures were affected by downward circulation of cool air from the upper surface and by upward flow of hot gases from the interior of the lake.

6. Thermal properties of the Alae basalt measured in the laboratory or calculated from laboratory data are in good agreement with values deduced from the thermal modeling. Values for the properties are as follows: 
(a) Conductivity $\left(K\right.$, in cal $\left./ \mathrm{cm} \mathrm{sec}{ }^{\circ} \mathrm{C}\right)$ increased with decreasing porosity $(\phi)$ and with increasing temperature $\left(T\right.$ in $\left.{ }^{\circ} \mathrm{C}\right)$, and can be represented by the following expression;

$$
K=(1.929-1.554 \phi)^{2}(1+0.0006 T)
$$

(b) Heat capacity $(c)$ can be represented by the following function of temperature ( $T$, in Kelvins): $c=0.2356+4.3635 \times 10^{-5} T-6.3440 \times 10^{3} / T^{2}$

(c) Thermal diffusivity varied with time and depth in the lake from about 0.005 to $0.006 \mathrm{~cm}^{2} / \mathrm{sec}$ with changing conductivity, density, and heat capacity.

(d) The latent heat for 80 percent crystallization of the basalt was $80 \pm 10 \mathrm{cal} / \mathrm{g}$.

The results of this investigation are pertinent to interpretations of the cooling histories of other basaltic lakes and flows, but they should be applied with caution. Such factors as mineralogical composition and vesicularity strongly affect thermal properties. Different modes of formation of the lake or flow may result in different initial temperature distributions. Temperatures in the upper part of Makaopuhi lava lake, for example, were decreased markedly by repeated crustal foundering during drain back of lava into the vent at the end of the eruption. Separate lakes and flows are subjected to different amounts of rainfall. Furthermore, the cooling effect of rain may be markedly less in thicker lakes, where a significant fraction of the vaporized rainwater condenses at shallow levels in the crust rather than escaping to the atmosphere.

\section{REFERENCES CITED}

Ault, W. U., Eaton, J. P., and Richter, D. H., 1961, Lava temperatures in the 1959 Kilauea eruption and cooling lake: Geol. Soc. America Bull., v. 72, no. 5, p. 791-794.

Ault, W. U., Richter, D. H., and Stewart, D. B., 1962, A temperature measurement probe into the melt of the Kilauea Iki lava lake in Hawaii: Jour. Geophys. Research, v. 67, no. 7, p. 2809-2812.

Birch, Francis, and Clark, Harry, 1940, The thermal conductivity of rocks and its dependence upon temperature and composition: Am. Jour. Sci., v. 238, no. 8, p. 529-558, no. 9, p. 613-635.

Bottinga, Y., and Weill, D. F., 1970, Densities of liquid silicate systems calculated from partial molar volumes of oxide components: Am. Jour. Sci., v. 269, no. 2, p. 169-182.

Bradley, R. S., 1962, Thermodynamic calculations on phase equilibria involving fused salts, Part 2, Solid solutions and applications to the olivines: Am. Jour. Sci., v. 260, no. 7, p. 550-554.

Carslaw, H. S., and Jaeger, 1959, Conduction of Heat in Solids: London, Oxford at the Clarendon Press, $510 \mathrm{p}$.

Daly, R. A., Manger, G. E., and Clark, S. P., Jr., 1966, Density of rocks, in Clark, S P., Jr., ed., Handbook of Physical Constants (rev. ed.): Geol. Soc. America Memoir 97, p. 19-26.

Dane, E. B., Jr., 1941, Density at high pressure; thermal expansion, in Birch, Francis, Schairer, J. R., and Spicer, H. C., Handbook of Physical Constants: Geol. Soc. America Spec. Paper 36, p. 27-37.

Decker, R.W., and Peck, D. L., 1967, Infrared radiation from Alae lava lake, Hawaii, in Geological Survey research 1967: U. S. Geol. Survey Prof. Paper 575-D, p. D169-D175.
Finlayson, J. B., Barnes, I. L., and Naughton, J. J., 1968, Developments in volcanic gas research in Hawaii, in The crust and upper mantle of the Pacific area: Am. Geophys. Union Geophys. Mon. 12 , p. $428-438$.

Kawada, Kaoru, 1966, Studies of the thermal state of the earth. The 17th Paper: Variation of thermal conductivity of rocks, Part 2: Bull. Earthquake Research Inst., Tokyo Univ., v. 44, p. 1-21.

Murase, Tsutomu, and McBirney, A. R., 1973, Properties of some common igneous rocks and their melts at high temperatures: Geol. Soc. America Bull., v. 84, p. 3563-3592.

Nafe, J. E., and Drake, C. L., 1968, Physical properties of rocks of basaltic composition, in Hess, H. H., and Poldervaart, Arie, eds.; Basalts, v. 2: New York and London, Interscience Pub., p. 483502.

Peck, D. L., 1969, Density of molten lava in Alae lava lake, Hawaii [abs.]: EOS, v. 50 , no. 4 , p. 339.

1974, Thermal properties of basaltic magma; results and practical experience from study of Hawaiian lava lakes-summary, in Colp, J. L., and Furumoto, A. S., eds., The Utilization of Volcano Energy: Sandia Laboratories, Albuquerque, p. 287-295.

Peck, D. L., Hamilton, M. S., and Shaw, H. R., 1977, Numerical analysis of lava lake cooling models; Part II, Application to Alae lava lake, Hawaii: Am. Jour. Sci., v. 277, p. 415-437.

Peck, D. L., and Kinoshita, W. T., 1976, The eruption of August 1963 and the formation of Alae lava lake, Hawaii: U. S. Geol. Survey Prof. Paper 935-A, p. A1-A33.

Peck, D. L., and Minakami, Takeshi, 1968, The formation of columnar joints in the upper part of Kilauean lava lakes, Hawaii: Geol. Soc. America Bull., v. 79, no. 9, p. 1151-1165.

Peck, D. L., Moore, J. G., and Kojima, George, 1964, Temperatures in the crust and melt of Alae lava lake, Hawaii, after the August 1963 eruption of Kilauea volcano-a preliminary report, in Geological Survey research 1964: U. S. Geol. Survey Prof. Paper 501-D, p. D1-D7.

Peck, D. L., Wright, T. L., and Moore, J. G., 1966, Crystallization of tholeiitic basalt in Alae lava lake, Hawaii: Bull. Volcanol., v. 29, p. 629-655.

Rawson, D. E., 1960, Drilling into molten lava in the Kilauea Iki volcanic crater, Hawaii: Nature, v. 188, p. 930-931.

Richter, D. H., and Moore, J. G., 1966, Petrology of the Kilauea Iki lava lake, Hawaii: U. S. Geol. Survey Prof. Paper 537-B, 26 p.

Richter, Dorothy, and Simmons, Gene, 1974, Thermal expansion behavior of igneous rocks: Int. Jour. Rock Mechanics and Mining Science, v. 11, p. 403-411.

Robertson, E. C., and Peck, D. L., 1974, Thermal conductivity of vesicular basalt from Hawaii: Jour. Geophys. Research, v. 79, no. 32 , p. $4875-4888$.

Robie, R. A., and Waldbaum, D. R., 1968, Thermodynamic properties of minerals and related substances at $298.15^{\circ} \mathrm{K}\left(25.0^{\circ} \mathrm{C}\right)$ and one atmosphere (1.013 bars) pressure and at higher temperatures: U. S. Geol. Survey Bull. 1259, p. 1-256.

Shaw, H. R., 1969, Rheology of basalt in the melting range: Jour. Petrology, v. 10, no. 3, p. 511-535.

Shaw, H. R., Hamilton, M. S., and Peck, D. L., 1977, Numerical analysis of lava lake cooling models; Part I, Description of the model: Am. Jour. Sci., v. 277, p. 384-414.

Shaw, H. R., Wright, T. L., Peck, D. L., and Okamura, R., 1968, The viscosity of basaltic magma: An analysis of field measurements in Makaopuhi lava lake, Hawaii: Am. Jour. Sci., v. 266, no. 4, p. 225-264.

Skinner, B. J., 1966, Thermal expansion, in Clark, S.P., Jr., ed., Handbook of Physical Constants (rev. ed.): Geol. Soc. America Mem. 97, p. 75-96.

Stearns, H. T., and Macdonald, G. A., 1946, Geology and groundwater resources of the Island of Hawaii: Hawaii Div. Hydrog- 
raphy, Bull. 9, $363 \mathrm{p}$.

Swanson, D. A., Duffield, W. A., Jackson, D. B., and Peterson, D. W., 1973, The complex filling of Alae crater, Kilauea volcano, Hawaii: Bull. Volcanol., v. 36 (1972) no. 1, p. 105-126.

Swanson, D. A., Jackson, D. B., Duffield, W.A., and Peterson, D. W., 1971, Mauna Ulu eruption, Kilauea Volcano: Geotimes, v. 16, no. 5, p. 12-16.

Swanson, D.A., and Peterson, D. W., 1972, Partial draining and crustal subsidence of Alae lava lake, Kilauea Volcano, Hawaii, in Geological Survey research 1972: U. S. Geol. Survey Prof. Paper 800-C, p. C1-C14.

Walsh, J. B., and Decker, E. R., 1966, Effect of pressure and saturating fluid on the thermal conductivity of compact rock: Jour. Geophys. Research, v. 71, no. 12, p. 3053-3061.

Wright, T. L., Kinoshita, W. T., and Peck, D. L., 1968, March 1965 eruption of Kilauea volcano and the formation of Makaopuhi lava lake: Jour. Geophys. Research, v. 73 , no. 10, p. 3181-3205. Wright, T. L., and Okamura, R. T., 1977, Cooling and crystallization of tholeiitic basalt, 1965, Makaopuhi lava lake, Hawaii: U.S. Geol. Survey Prof. Paper 1004, 78 p.

Wright, T. L., and Peck, D. L., 1978, Crystallization and differentiation of the Alae magma: U.S. Geol. Survey Prof. Paper 935-C (in press).

Wright, T. L., Peck, D. L., and Shaw, H. R., 1976, Kilauean lava lakes: natural laboratories for study of cooling, crystallization, and differentiation of basaltic magma: Am. Geophys. Union Geophys. Mon. 19, p. 375-390.

Wright, T. L., and Weiblen, P. W., 1968, Mineral composition and paragenesis in tholeiitic basalt from Makaopuhi lava lake, Hawaii [abs.]: Geol. Soc. America, Spec. Paper 115, p. 242.

Yoder, H. S., Jr., 1975, Heat of melting of simple systems related to basalts and eclogites: Carnegie Inst. Wash. Year Book 74, p. $515-519$. 
TABLE 3 
TABLE 3.-Temperatures in Alae lava lake

[Temperatures measured with thermocouples of chromel-alumel unless noted otherwise. Profiles used in constructing fig. 10 are marked by an asterisk $(*)$. Square root of time in days after 06h Aug. 22, 1963, in parentheses]

\begin{tabular}{|c|c|c|c|}
\hline $\begin{array}{l}\text { Drill hole } \\
\text { No. }\end{array}$ & Time $^{1}$ & $\begin{array}{c}\text { Depth}^{2} \\
\text { (ft) }\end{array}$ & $\begin{array}{l}\text { Temperature } \\
\left({ }^{\circ} \mathrm{C}\right)\end{array}$ \\
\hline
\end{tabular}

\begin{tabular}{|c|c|c|c|}
\hline \multicolumn{4}{|c|}{ August 30, $1963(2.87)$} \\
\hline DH1 $1_{--}$ & $10 \mathrm{~h} 58 \mathrm{~m}-11 \mathrm{~h} 46 \mathrm{~m}$ & $\begin{array}{l}0.0 \\
.5 \\
1.0 \\
1.5 \\
2.0 \\
2.5 \\
2.7\end{array}$ & $\begin{array}{c}351.60 \\
272 \\
496 \\
668 \\
817 \\
925 \\
954\end{array}$ \\
\hline \multicolumn{4}{|c|}{ September 3, 1963 (3.49) } \\
\hline DH1 & $10 \mathrm{~h} 31 \mathrm{~m}-10 \mathrm{~h} 58 \mathrm{~m}$ & $\begin{array}{l}1.0 \\
1.5 \\
2.0 \\
2.5 \\
2.7\end{array}$ & $\begin{array}{l}489 \\
623 \\
748 \\
846 \\
868\end{array}$ \\
\hline
\end{tabular}

September 4, $1963(3.63)$

\begin{tabular}{|c|c|c|c|}
\hline DH1 -- & $9 \mathrm{~h} 50 \mathrm{~m}-11 \mathrm{~h} 20 \mathrm{~m} \quad---$ & $\begin{array}{l}0.5 \\
1.0 \\
1.5 \\
2.0 \\
2.5 \\
3.0 \\
3.5 \\
3.75\end{array}$ & $\begin{array}{l}264 \\
439 \\
578 \\
709 \\
822 \\
914 \\
993 \\
1,022\end{array}$ \\
\hline \multicolumn{4}{|c|}{ September 6, $1963(3.90)$} \\
\hline *DHL & $10 \mathrm{~h} 29 \mathrm{~m}-11 \mathrm{~h} 11 \mathrm{~m}$ & $\begin{array}{l}0.5 \\
1.0 \\
1.5 \\
2.0 \\
2.5 \\
3.0 \\
3.5 \\
3.55 \\
3.65\end{array}$ & $\begin{array}{r}274 \\
440 \\
569 \\
691 \\
794 \\
882 \\
951 \\
4960 \\
4971\end{array}$ \\
\hline \multicolumn{4}{|c|}{ September 9, $1963(4.27)$} \\
\hline DH1 & $11 \mathrm{~h} 25 \mathrm{~m}-13 \mathrm{~h} 38 \mathrm{~m}$ & $\begin{array}{l}0.5 \\
1.0 \\
1.5 \\
2.0 \\
2.5 \\
3.0 \\
3.5 \\
4.0 \\
4.25 \\
4.25\end{array}$ & $\begin{array}{r}246 \\
397 \\
528 \\
643 \\
742 \\
826 \\
898 \\
967 \\
991 \\
4997\end{array}$ \\
\hline $\mathrm{DH} 2_{--}$ & -................. & $\begin{array}{r}.5 \\
1.0 \\
1.5 \\
2.0 \\
2.5\end{array}$ & $\begin{array}{l}4263 \\
4425 \\
4564 \\
4656 \\
4681\end{array}$ \\
\hline
\end{tabular}

TABLE 3.-Temperatures in Alae lava lake-Continued

\begin{tabular}{|c|c|c|c|}
\hline $\begin{array}{l}\text { Drill hole } \\
\text { No. }\end{array}$ & Time $^{1}$ & $\begin{array}{c}\text { Depth}^{2} \\
\text { (ft) }\end{array}$ & $\begin{array}{l}\text { Temperature } \\
\left({ }^{\circ} \mathrm{C}\right)\end{array}$ \\
\hline \multicolumn{4}{|c|}{ September 11, 1963 (4.50) } \\
\hline *DH1 & $10 \mathrm{~h} 30 \mathrm{~m}-12 \mathrm{~h} 27 \mathrm{~m}$ & $\begin{array}{l}0.0 \\
.5 \\
1.0 \\
1.5 \\
2.0 \\
2.5 \\
3.0 \\
3.5 \\
4.0 \\
4.25 \\
4.25 \\
.5 \\
1.0 \\
1.5 \\
2.0 \\
2.15\end{array}$ & $\begin{array}{l}67 \\
235 \\
392 \\
517 \\
626 \\
717 \\
799 \\
877 \\
942 \\
965 \\
4968 \\
4266 \\
4414 \\
4537 \\
4637 \\
4662\end{array}$ \\
\hline
\end{tabular}

September 17, $1963(5.12)$

$\begin{array}{lrrr}* \mathrm{DH} 11_{--} \quad 9 \mathrm{~h} 39 \mathrm{~m}-10 \mathrm{~h} 47 \mathrm{~m} & --- & 1.0 & 4339 \\ & & 2.0 & 4581 \\ & & 3.0 & 4736 \\ & & 3.5 & 4806 \\ & & 4.0 & 4870 \\ & & 4.2 & 4899\end{array}$

September 24, 1963 (5.76)

$\begin{array}{rrr}* \mathrm{DH} 1--\quad 10 \mathrm{~h} 05 \mathrm{~m}-12 \mathrm{~h} 06 \mathrm{~m}--- & 0.5 & 4200 \\ & 1.0 & 4312 \\ 1.5 & 4417 \\ 2.0 & 4511 \\ 2.5 & 4594 \\ 3.0 & 4668 \\ 3.5 & 4734 \\ 4.0 & 4795 \\ 4.5 & 4854 \\ 5.0 & 4907 \\ & 5.4 & 4939\end{array}$

September 26, 1963 (5.93)

\begin{tabular}{rrr}
\hline DH1_- $10 \mathrm{~h} 05 \mathrm{~m}-11 \mathrm{~h} 49 \mathrm{~m}---$ & .5 & 4167 \\
& 1.0 & 4295 \\
1.5 & 4403 \\
2.0 & 4503 \\
2.5 & 4584 \\
3.0 & 4657 \\
3.5 & 4724 \\
4.0 & 4784 \\
4.5 & 4839 \\
5.0 & 4891 \\
& 5.4 & 4923
\end{tabular}

October 1, $1963(6.30)$

*DH1 1 9h35m-10h48m

$\begin{array}{ll}1.4 & 4357 \\ 1.9 & 4456 \\ 2.4 & 4541 \\ 2.9 & 4614 \\ 3.4 & 4680 \\ 3.9 & 4740 \\ 4.4 & 4798 \\ 4.9 & 4843 \\ 5.4 & 4889\end{array}$


COOLING AND VESICULATION OF ALAE LAVA LAKE, HAWAII

TABLE 3.-Temperatures in Alae lava lake-Continued

\begin{tabular}{|c|c|c|c|}
\hline $\begin{array}{l}\text { Drill hole } \\
\text { No. }\end{array}$ & Time $^{1}$ & $\begin{array}{c}\text { Depth}{ }^{2} \\
\text { (ft) }\end{array}$ & $\begin{array}{l}\text { Temperature } \\
\left({ }^{\circ} \mathrm{C}\right)\end{array}$ \\
\hline \multicolumn{4}{|c|}{ October 2, 1963 (6.42) } \\
\hline DH3 & 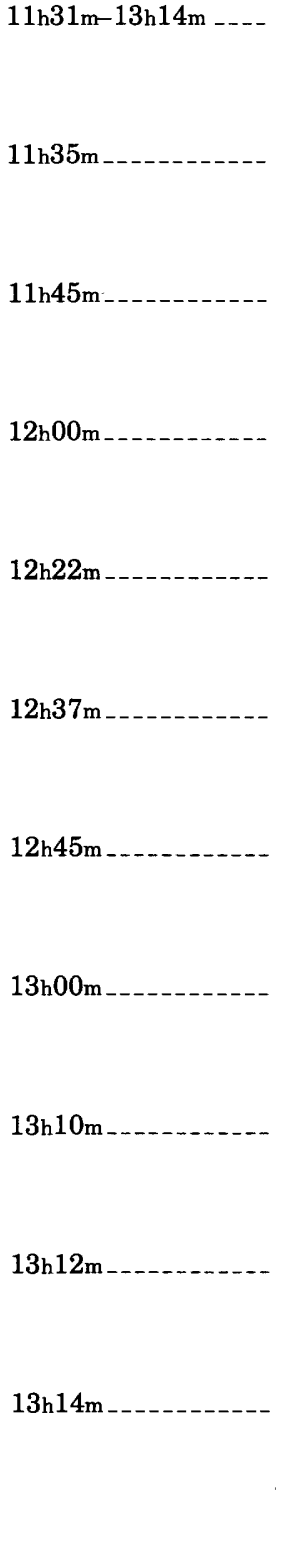 & $\begin{array}{c}7.5 \\
8.0 \\
8.5 \\
9.0 \\
9.5 \\
7.5 \\
8.0 \\
8.5 \\
9.0 \\
9.5 \\
7.5 \\
8.0 \\
8.5 \\
9.0 \\
9.5 \\
7.55 \\
8.05 \\
8.55 \\
9.05 \\
9.55 \\
7.6 \\
8.1 \\
8.6 \\
9.1 \\
9.6 \\
7.6 \\
8.1 \\
8.6 \\
9.1 \\
9.6 \\
7.6 \\
8.1 \\
8.6 \\
9.1 \\
9.6 \\
7.7 \\
8.2 \\
8.7 \\
9.2 \\
9.7 \\
7.9 \\
8.4 \\
8.9 \\
9.4 \\
9.9 \\
8.1 \\
8.6 \\
9.1 \\
9.6 \\
10.1 \\
8.1 \\
8.6 \\
9.1 \\
9.6 \\
10.1\end{array}$ & $\begin{array}{l}906 \\
985 \\
1,026 \\
1,056 \\
1,050 \\
926 \\
1,000 \\
1,037 \\
1,063 \\
1,053 \\
955 \\
1,018 \\
1,047 \\
1,069 \\
1,058 \\
983 \\
1,031 \\
1,056 \\
1,074 \\
1,062 \\
1,002 \\
1,039 \\
1,063 \\
1,078 \\
1,065 \\
1,011 \\
1,044 \\
1,067 \\
1,079 \\
1,066 \\
1,016 \\
1,046 \\
1,068 \\
1,079 \\
1,065 \\
1,022 \\
1,051 \\
1,070 \\
1,078 \\
1,064 \\
1,033 \\
1,058 \\
1,075 \\
1,076 \\
1,066 \\
1,043 \\
1,065 \\
1,075 \\
1,071 \\
1,075 \\
1,045 \\
1,066 \\
1,079 \\
1,070 \\
1,084\end{array}$ \\
\hline \multicolumn{4}{|c|}{ October 17, 1963 (7.50) } \\
\hline * DH1 & $11 \mathrm{~h} 39 \mathrm{~m}-11 \mathrm{~h} 52 \mathrm{~m} \ldots$ & $\begin{array}{l}0.5 \\
1.0 \\
1.5 \\
2.0 \\
2.5 \\
3.4 \\
3.9 \\
4.4 \\
4.9 \\
5.4\end{array}$ & $\begin{array}{l}141 \\
239 \\
332 \\
416 \\
492 \\
596 \\
654 \\
705 \\
758 \\
798\end{array}$ \\
\hline
\end{tabular}

See footnotes at end of table.
TABLE 3.-Temperatures in Alae lava lake-Continued

\begin{tabular}{|c|c|c|c|}
\hline $\begin{array}{l}\text { Drill hole } \\
\text { No. }\end{array}$ & Time $^{1}$ & $\underset{(\mathrm{ft})}{\mathrm{Depth}^{2}}$ & $\begin{array}{c}\text { Temperature } \\
\left({ }^{\circ} \mathrm{C}\right)\end{array}$ \\
\hline & \multicolumn{3}{|c|}{ October 24, $1963(7.95)$} \\
\hline \multirow[t]{11}{*}{ DH3 } & $09 \mathrm{~h} 55 \mathrm{~m}-10 \mathrm{~h} 22 \mathrm{~m}$ & 0.8 & 255 \\
\hline & & 1.3 & $\begin{array}{l}336 \\
409\end{array}$ \\
\hline & & $\begin{array}{l}1.8 \\
2.3\end{array}$ & $\begin{array}{l}409 \\
481\end{array}$ \\
\hline & & 3.3 & 602 \\
\hline & & 3.8 & $65 \overline{5}$ \\
\hline & & 4.3 & 701 \\
\hline & & 4.8 & 745 \\
\hline & & 5.8 & 824 \\
\hline & & 6.3 & 865 \\
\hline & & 6.8 & 903 \\
\hline & & 7.3 & 939 \\
\hline \multirow[t]{4}{*}{ DH1_- } & $10 \mathrm{~h} 40 \mathrm{~m}$ & 3.4 & 589 \\
\hline & & 3.9 & 639 \\
\hline & & 4.4 & 691 \\
\hline & & 4.9 & 740 \\
\hline \multirow{7}{*}{ DH3 .. } & $15 \mathrm{~h} 00 \mathrm{~m}-16 \mathrm{~h} 04 \mathrm{~m}$ & 10.0 & ${ }^{41}, 043$ \\
\hline & & 11.0 & ${ }^{41,077}$ \\
\hline & & 11.5 & ${ }^{4} 1,079$ \\
\hline & & 12.5 & ${ }^{41,108}$ \\
\hline & & 13.0 & 41,113 \\
\hline & & 13.5 & 41,117 \\
\hline & & 14.0 & ${ }^{4} 1,121$ \\
\hline
\end{tabular}

November 5, 1963 (8.68)

\begin{tabular}{|c|c|c|c|}
\hline 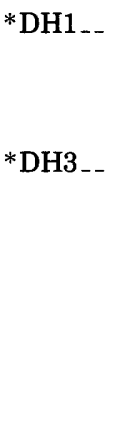 & $13 \mathrm{~h} 46 \mathrm{~m}-14 \mathrm{~h} 16 \mathrm{~m}$ & $\begin{array}{l}1.4 \\
2.4 \\
3.4 \\
4.4 \\
5.4 \\
1.0 \\
2.0 \\
3.0 \\
4.0 \\
5.0 \\
5.8 \\
6.8 \\
7.8 \\
8.8 \\
9.8\end{array}$ & $\begin{array}{l}291 \\
427 \\
534 \\
637 \\
726 \\
185 \\
365 \\
509 \\
616 \\
710 \\
778 \\
855 \\
925 \\
987 \\
1,035\end{array}$ \\
\hline
\end{tabular}

November 7, $1963(8.79)$

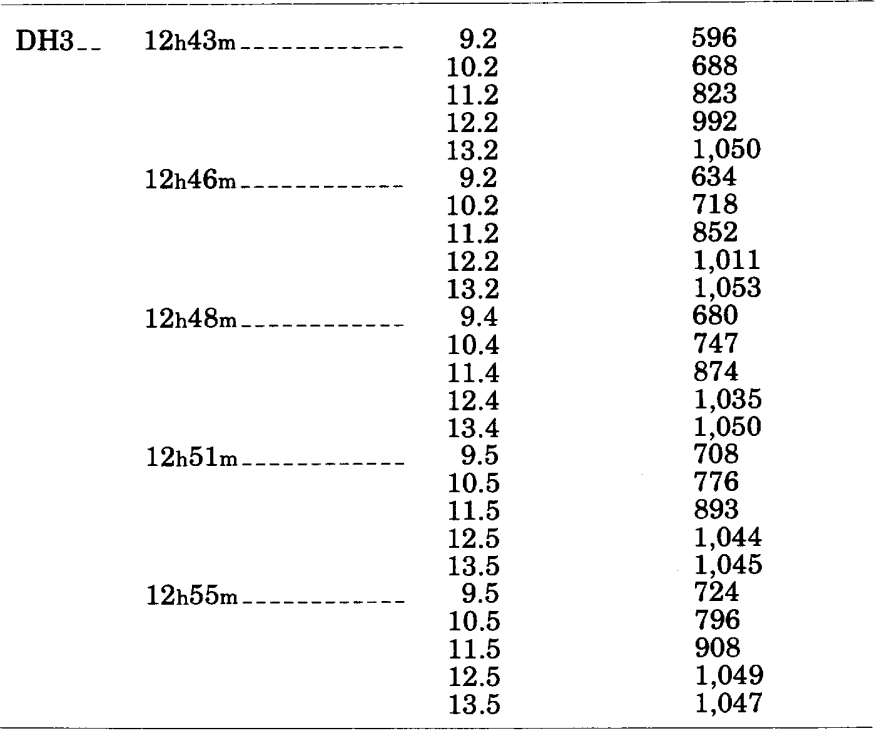


TABLE 3.-Temperatures in Alae lava lake-Continued

\begin{tabular}{|c|c|c|c|}
\hline $\begin{array}{l}\text { Drill hole } \\
\text { No. }\end{array}$ & Time $^{1}$ & $\begin{array}{c}\text { Depth }^{2} \\
\text { (ft) }\end{array}$ & $\begin{array}{c}\text { Temperature } \\
\left({ }^{\circ} \mathrm{C}\right)\end{array}$ \\
\hline \multirow[t]{73}{*}{ DH3 $\ldots$} & $13 \mathrm{~h} 00 \mathrm{~m}$ & 9.5 & 740 \\
\hline & & 10.5 & 816 \\
\hline & & 11.5 & 924 \\
\hline & & 12.5 & 1,053 \\
\hline & & 13.5 & 1,048 \\
\hline & $13 \mathrm{~h} 05 \mathrm{~m} \ldots$ & 9.5 & 754 \\
\hline & & 10.5 & 832 \\
\hline & & 11.5 & 934 \\
\hline & & 12.5 & 1,057 \\
\hline & & 13.5 & 1,051 \\
\hline & $13 \mathrm{~h} 10 \mathrm{~m}$ & 9.5 & 765 \\
\hline & & 10.5 & 845 \\
\hline & & 11.5 & 948 \\
\hline & & 12.5 & 1,059 \\
\hline & & 13.5 & 1,052 \\
\hline & $13 \mathrm{~h} 15 \mathrm{~m}$ & 9.5 & 776 \\
\hline & & 10.5 & 858 \\
\hline & & 11.5 & 958 \\
\hline & & 12.5 & 1,061 \\
\hline & & 13.5 & 1,054 \\
\hline & $13 \mathrm{~h} 19 \mathrm{~m} \ldots$ & 9.5 & 784 \\
\hline & & 10.5 & 866 \\
\hline & & 11.5 & 964 \\
\hline & & 12.5 & 1,063 \\
\hline & & 13.5 & 1,056 \\
\hline & $13 \mathrm{~h} 26 \mathrm{~m}_{---}$ & 9.5 & 796 \\
\hline & & 10.5 & 879 \\
\hline & & 11.5 & 974 \\
\hline & & 12.5 & 1,065 \\
\hline & & 13.5 & 1,057 \\
\hline & $13 \mathrm{~h} 30 \mathrm{~m}$ & 9.5 & 807 \\
\hline & & 10.5 & 887 \\
\hline & & 11.5 & 981 \\
\hline & & 12.5 & 1,069 \\
\hline & & 13.5 & 1,062 \\
\hline & $13 \mathrm{~h} 31 \mathrm{~m}$ & 12.5 & 1,070 \\
\hline & & 13.5 & 1,062 \\
\hline & $13 \mathrm{~h} 33 \mathrm{~m} \ldots \ldots$ & 12.5 & 1,070 \\
\hline & & 13.5 & 1,062 \\
\hline & $13 \mathrm{~h} 34 \mathrm{~m} \ldots \ldots$ & 9.5 & 811 \\
\hline & & 10.5 & 894 \\
\hline & & 11.5 & 986 \\
\hline & & 12.5 & 1,071 \\
\hline & & 13.5 & 1,063 \\
\hline & $13 \mathrm{~h} 37 \mathrm{~m}$ & 12.5 & 1,071 \\
\hline & & 13.5 & 1,063 \\
\hline & $13 \mathrm{~h} 39 \mathrm{~m} \ldots \ldots$ & 9.5 & 817 \\
\hline & & 10.5 & 901 \\
\hline & & 11.5 & 992 \\
\hline & & 12.5 & 1,072 \\
\hline & & 13.5 & 1,064 \\
\hline & $13 \mathrm{~h} 41 \mathrm{~m}$ & 12.5 & 1,073 \\
\hline & & 13.5 & 1,064 \\
\hline & $13 \mathrm{~h} 43 \mathrm{~m} \ldots$ & 9.5 & 824 \\
\hline & & 10.5 & 907 \\
\hline & & 11.5 & 999 \\
\hline & & 12.5 & 1,074 \\
\hline & & 13.5 & 1,065 \\
\hline & $13 \mathrm{~h} 45 \mathrm{~m}$ & 12.5 & 1,074 \\
\hline & & 13.5 & 1,065 \\
\hline & $13 \mathrm{~h} 46 \mathrm{~m} \ldots \ldots$ & 11.55 & 1,001 \\
\hline & & 12.55 & 1,075 \\
\hline & & 13.55 & 1,065 \\
\hline & $13 \mathrm{~h} 47 \mathrm{~m}$ & 12.55 & 1,075 \\
\hline & & 13.55 & 1,066 \\
\hline & $13 \mathrm{~h} 48 \mathrm{~m}$ & 12.6 & 1,076 \\
\hline & & 13.6 & 1,067 \\
\hline & $13 \mathrm{~h} 49 \mathrm{~m}$ & 12.6 & 1,078 \\
\hline & & 13.6 & 1,067 \\
\hline & $13 \mathrm{~h} 50 \mathrm{~m}$ & 12.7 & 1,080 \\
\hline & & 13.7 & 1,067 \\
\hline & $13 \mathrm{~h} 51 \mathrm{~m}$ & 13.0 & 1,081 \\
\hline & & 14.0 & 1,064 \\
\hline
\end{tabular}

TABLE 3.-Temperatures in Alae lava lake-Continued

\begin{tabular}{|c|c|c|c|}
\hline $\begin{array}{l}\text { Drill hole } \\
\text { No. }\end{array}$ & Time $^{1}$ & $\operatorname{Depth}_{(\mathrm{ft})}{ }^{2}$ & $\begin{array}{c}\text { Temperature } \\
\left(^{\circ} \mathrm{C}\right)\end{array}$ \\
\hline \multicolumn{4}{|c|}{ November 8, $1963(8.85)$} \\
\hline DH3 & $11 \mathrm{~h} 36 \mathrm{~m}-12 \mathrm{~h} 48 \mathrm{~m}$ & $\begin{array}{r}1.0 \\
2.0 \\
3.0 \\
4.0 \\
5.0 \\
6.0 \\
7.0 \\
8.0 \\
8.9 \\
9.0 \\
9.4 \\
9.9 \\
10.0 \\
10.4 \\
10.8 \\
10.9 \\
11.4 \\
11.8 \\
11.9 \\
12.4 \\
12.8 \\
12.9 \\
13.4 \\
13.8 \\
13.9 \\
14.8 \\
14.9 \\
15.9 \\
16.9 \\
17.9\end{array}$ & $\begin{array}{l}94 \\
97 \\
94 \\
269 \\
436 \\
593 \\
741 \\
858 \\
944 \\
944 \\
979 \\
1,008 \\
1,005 \\
1,034 \\
1,053 \\
1,055 \\
1,071 \\
1,085 \\
1,086 \\
1,095 \\
1,112 ? \\
1,099,1,100 \\
1,104 \\
1,110 \\
1,114 ; 1,115 ; 1,115 \\
1,123 \\
1,124 ; 1,126 ; 1,125 \\
1,129 ; 1,130 ; 1,131 \\
1,134 ; 1,132 ; 1,132 \\
1,136 ; 1,135\end{array}$ \\
\hline
\end{tabular}

November 20, 1963 (9.50)

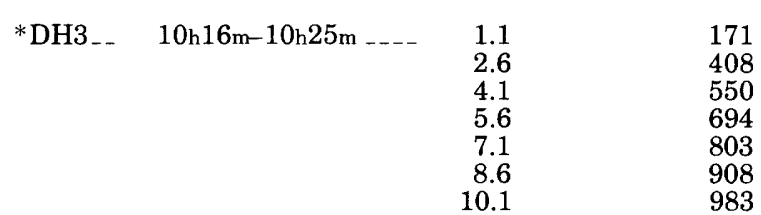

November 27, 1963 (9.86)

$\begin{array}{rrr}\mathrm{DH} 4 \ldots+14 \mathrm{~h} 30 \mathrm{~m} \ldots & 11.3 & 810 \\ & 12.3 & 897 \\ & 13.3 & 948 \\ & 14.3 & 974 \\ & 15.3 & 702 \\ 14 \mathrm{~h} 48 \mathrm{~m} \ldots & 11.3 & 827 \\ & 12.3 & 918 \\ & 13.3 & 969 \\ & 14.3 & 997 \\ & 15.3 & 760\end{array}$

November 28, 1963 (9.91)

$\begin{array}{rrr}\mathrm{DH} 44_{--} \quad 10 \mathrm{~h} 42 \mathrm{~m}-10 \mathrm{~h} 57 \mathrm{~m}---\quad 6.0 & 481 \\ & 7.0 & 586 \\ 8.0 & 693 \\ 9.0 & 797 \\ 10.0 & 886 \\ 11.2 & 981 \\ 12.2 & 1,035 \\ 13.2 & 1,065 \\ 14.2 & 1,068 \\ 15.2 & 1,058\end{array}$


TABLE 3.-Temperatures in Alae lava lake-Continued

\begin{tabular}{|c|c|c|c|}
\hline $\begin{array}{l}\text { Drill hole } \\
\text { No. }\end{array}$ & Time $^{1}$ & $\underset{\text { Depth }}{\text { Det }^{2}}$ & $\begin{array}{c}\text { Temperature } \\
\left({ }^{\circ} \mathrm{C}\right)\end{array}$ \\
\hline \multicolumn{4}{|c|}{ December 2, 1963 (10.11) } \\
\hline DH4 & $12 \mathrm{~h} 25 \mathrm{~m}-13 \mathrm{~h} 30 \mathrm{~m}$ & $\begin{array}{r}3.0 \\
3.5 \\
4.0 \\
4.5 \\
5.0 \\
5.5 \\
6.0 \\
6.5 \\
7.0 \\
7.5 \\
8.0 \\
8.5 \\
9.0 \\
9.5 \\
10.0 \\
10.5 \\
11.0 \\
11.5 \\
12.0 \\
12.5 \\
13.0 \\
13.5 \\
14.0 \\
14.5 \\
15.0 \\
15.5 \\
16.0 \\
16.5 \\
17.0 \\
17.5 \\
18.0\end{array}$ & $\begin{array}{l}323 \\
377 \\
425 \\
470 \\
514 \\
559 \\
612,598 \\
657 \\
698 \\
740 \\
781 \\
820 \\
849,853 \\
884 \\
917 \\
946 \\
974 \\
1,001 \\
1,013 ; 1,022 \\
1,033 \\
1,048 \\
1,059 \\
1,066 \\
1,071 \\
1,062 ; 1,075 \\
1,071 \\
1,079 \\
1,088 \\
1,094 \\
1,099 \\
1,100\end{array}$ \\
\hline \multicolumn{4}{|c|}{ December 5, 1963 (10.26) } \\
\hline $\mathrm{DH} 4_{--}$ & $10 \mathrm{~h} 12 \mathrm{~m}-13 \mathrm{~h} 22 \mathrm{~m}$ & $\begin{array}{r}1.0 \\
2.0 \\
3.0 \\
4.0 \\
5.0 \\
6.0 \\
7.0 \\
8.0 \\
9.0 \\
10.0 \\
11.0 \\
12.0 \\
13.0 \\
14.0 \\
15.0 \\
16.0\end{array}$ & $\begin{array}{l}4127 \\
4240 \\
4357 \\
4456 \\
4546 \\
4635 \\
4715 \\
4793 \\
4864 \\
4926 \\
4981 \\
41,010 \\
41,048 \\
41,069 \\
41,086 \\
41,102\end{array}$ \\
\hline \multicolumn{4}{|c|}{ December 16, 1963 (10.78) } \\
\hline $\mathrm{DH}_{4}$ & $10 \mathrm{~h} 45 \mathrm{~m}-15 \mathrm{~h} 28 \mathrm{~m}$ & $\begin{array}{r}1.0 \\
2.0 \\
3.0 \\
4.0 \\
5.0 \\
6.0 \\
7.0 \\
8.0 \\
9.0 \\
10.0 \\
11.0 \\
12.0 \\
13.0 \\
13.3 \\
13.8 \\
14.0 \\
14.3\end{array}$ & $\begin{array}{l}158 \\
284 \\
399 \\
493 \\
573 \\
653 \\
724 \\
794 \\
857 \\
911 \\
953 \\
995 \\
1,034 \\
1,045 \\
1,060 \\
1,061 \\
1,064\end{array}$ \\
\hline
\end{tabular}

TABLE 3.-Temperatures in Alae lava lake-Continued

\begin{tabular}{|c|c|c|c|}
\hline $\begin{array}{l}\text { Drill hole } \\
\text { No. }\end{array}$ & Time $^{1}$ & $\begin{array}{l}\text { Depth }{ }^{2} \\
(\mathrm{ft})\end{array}$ & $\begin{array}{c}\text { Temperature } \\
\left({ }^{\circ} \mathbf{C}\right)\end{array}$ \\
\hline DH4_-- & $10 \mathrm{~h} 45 \mathrm{~m}-15 \mathrm{~h} 28 \mathrm{~m}_{-\ldots}$ & $\begin{array}{l}14.8 \\
15.0 \\
15.3 \\
15.8 \\
16.3 \\
16.8 \\
17.3 \\
17.8 \\
17.0\end{array}$ & $\begin{array}{l}1,073 \\
1,075 \\
1,079 \\
1,087 \\
1,089 \\
1,094 \\
1,095 \\
1,098 \\
41,096 ; 1,086\end{array}$ \\
\hline
\end{tabular}

December 18, 1963 (10.79)

\begin{tabular}{rll}
\hline$* \mathrm{DH} 4{ }_{--} \quad 11 \mathrm{~h} 21 \mathrm{~m}-12 \mathrm{~h} 21 \mathrm{~m}-\ldots-$ & 0.0 & 67 \\
& 1.0 & 172 \\
& 2.0 & 289 \\
3.0 & 394 \\
4.0 & 484 \\
5.0 & 567 \\
6.0 & 643 \\
7.0 & 713 \\
8.0 & 779 \\
9.0 & 837 \\
10.0 & 904 \\
11.0 & 950 \\
12.0 & 995 \\
13.0 & 1,031 \\
13.5 & 1,049 \\
13.85 & 1,062 \\
14.0 & 1,058 \\
14.5 & 1,069 \\
14.85 & 1,078 \\
15.5 & 1,083 \\
15.85 & 1,091 \\
16.5 & 1,094 \\
16.85 & 1,101 \\
1.5 & 1,100 \\
17.85 & 1,106
\end{tabular}

December 30, 1963 (11.41)

$\begin{array}{lll}* \mathrm{DH} 4--\quad 10 \mathrm{~h} 16 \mathrm{~m}-13 \mathrm{~h} 25 \mathrm{~m}--- & 0.0 & 358 \\ 1.0 & 196 \\ 2.0 & 302 \\ 3.0 & 395 \\ 4.0 & 477 \\ 5.0 & 547 \\ 6.0 & 639 \\ 7.0 & 700 \\ 8.0 & 758 \\ 9.0 & 812 \\ 10.0 & 861 \\ 11.0 & 926,934 \\ 11.75 & 968 \\ 12.0 & 970,980,975 \\ 12.25 & 990 \\ 12.5 & 999 \\ 12.75 & 1,005 \\ 13.0 & 1,005 ; 1,018 ; 1,015 ; 1,009 \\ 13.25 & 1,024 ; 1,025 \\ 13.5 & 1,031 ; 1,032 ; 1,036 \\ 13.75 & 1,036 ; 1,043 \\ 13.85 & 1,042 \\ 14.0 & 1,042 ; 1,048 ; 1,044 ; 1,043 \\ 14.25 & 1,053 ; 1,050 \\ 14.5 & 1,057 ; 1,056 ; 1,060 \\ 14.75 & 1,062 ; 1,064 \\ 14.85 & 1,064 \\ 15.0 & 1,063 ; 1,063 ; 1,064 ; 1,063 \\ 15.25 & 1,065 ; 1,068 \\ 15.5 & 1,069 ; 1,074 ; 1,073 \\ 15.75 & 1,079 ; 1,077 \\ 15.85 & 1,076 \\ 16.0 & 1,083 ; 1,084 \\ & \end{array}$

See footnotes at end of table. 
TABLE 3.-Temperatures in Alae lava lake-Continued

\begin{tabular}{|c|c|c|c|}
\hline $\begin{array}{l}\text { Drill hole } \\
\text { No. }\end{array}$ & Time $^{1}$ & $\begin{array}{c}\text { Depth}{ }^{2} \\
\text { (ft) }\end{array}$ & $\begin{array}{l}\text { Temperature } \\
\left({ }^{\circ} \mathrm{C}\right)\end{array}$ \\
\hline \multicolumn{4}{|c|}{ December 30, 1963 (11.41)—Continued } \\
\hline * DH4 & $10 \mathrm{~h} 16 \mathrm{~m}-13 \mathrm{~h} 25 \mathrm{~m}_{----}$ & $\begin{array}{l}16.25 \\
16.5 \\
16.75 \\
16.85 \\
17.0 \\
17.25 \\
17.5 \\
17.75 \\
17.85\end{array}$ & $\begin{array}{l}1,085 ; 1,086 \\
1,088 ; 1,089 ; 1,089 \\
1,091 \\
1,092 \\
1,097 \\
1,098 \\
1,100 ; 1,100 \\
1,101 \\
1,103\end{array}$ \\
\hline DH5 -- & $14 \mathrm{~h} 09 \mathrm{~m}-15 \mathrm{~h} 14 \mathrm{~m}$ & $\begin{array}{r}0.0 \\
1.0 \\
2.0 \\
3.0 \\
4.0 \\
5.0 \\
6.0 \\
7.0 \\
8.0 \\
9.0 \\
10.0 \\
11.0 \\
12.0 \\
13.0 \\
14.0 \\
15.0 \\
15.5 \\
16.0 \\
16.5 \\
17.0 \\
17.5 \\
18.0 \\
18.5 \\
19.0 \\
19.5 \\
20.0\end{array}$ & $\begin{array}{l}345 \\
128 \\
217 \\
292 \\
365 \\
434 \\
526 \\
594 \\
655 \\
713 \\
766 \\
842 \\
887 \\
928 \\
963 \\
993 \\
1,021 \\
1,032 \\
1,038 \\
1,045 \\
1,049 \\
1,052 \\
1,050 \\
1,050 \\
1,044 \\
1,041\end{array}$ \\
\hline
\end{tabular}

January 29, 1964 (12.70)

\begin{tabular}{rll}
\hline *DH4_- $\quad 12 \mathrm{~h} 11 \mathrm{~m}-14 \mathrm{~h} 48 \mathrm{~m}-\ldots-$ & 1.0 & 95 \\
& 2.0 & 161 \\
3.0 & 272 \\
4.0 & 374,362 \\
5.0 & 453,436 \\
6.0 & 533,528 \\
7.0 & 602,596 \\
8.0 & $683,670,660$ \\
9.0 & 743,728 \\
9.3 & 765 \\
10.0 & 796,781 \\
10.3 & 818 \\
11.0 & 846 \\
11.3 & 867 \\
12.0 & 891 \\
12.3 & 912 \\
13.3 & 953
\end{tabular}

February 17, 1964 (13.43)

\begin{tabular}{rrr}
\hline DH5_- $10 \mathrm{~h} 35 \mathrm{~m}-13 \mathrm{~h} 25 \mathrm{~m}---$ & 1.5 & 100,97 \\
& 3.0 & 101,97 \\
4.5 & 101,97 \\
6.0 & 441 \\
7.5 & 563,555 \\
9.0 & 641,633 \\
10.5 & 711,704 \\
12.0 & 767,760 \\
13.5 & 817,809 \\
15.0 & 853,844 \\
15.5 & 879,877
\end{tabular}

TABLE 3.-Temperatures in Alae lava lake-Continued

\begin{tabular}{|c|c|c|c|}
\hline $\begin{array}{l}\text { Drill hole } \\
\text { No. }\end{array}$ & Time $^{1}$ & $\underset{(\mathrm{ft})}{\operatorname{Depth}}$ & $\begin{array}{l}\text { Temperature } \\
\left({ }^{\circ} \mathrm{C}\right)\end{array}$ \\
\hline DH5_- & $10 \mathrm{~h} 35 \mathrm{~m}-13 \mathrm{~h} 25 \mathrm{~m}$ & $\begin{array}{l}16.85 \\
18.5 \\
19.85 \\
21.5 \\
22.85 \\
24.5 \\
25.85 \\
27.5 \\
28.85\end{array}$ & $\begin{array}{l}899 \\
917,912 \\
913 \\
902,897 \\
876 \\
842,836 \\
801 \\
750,745 \\
701\end{array}$ \\
\hline *DH4 & $14 \mathrm{~h} 05 \mathrm{~m}-15 \mathrm{~h} 28 \mathrm{~m}$ & $\begin{array}{r}1.0 \\
2.0 \\
3.0 \\
4.0 \\
5.0 \\
6.0 \\
7.0 \\
8.0 \\
9.0 \\
9.2 \\
10.0 \\
10.2 \\
11.2 \\
12.2 \\
13.2\end{array}$ & $\begin{array}{l}95,96 \\
93,97 \\
176,195 \\
307,318 \\
399,407 \\
504,506 \\
569,572 \\
631,633 \\
687,690 \\
716 \\
738,739 \\
769 \\
818 \\
865 \\
907\end{array}$ \\
\hline
\end{tabular}

March 24, 1964 (14.71)

\begin{tabular}{|c|c|c|c|}
\hline *DH4 & 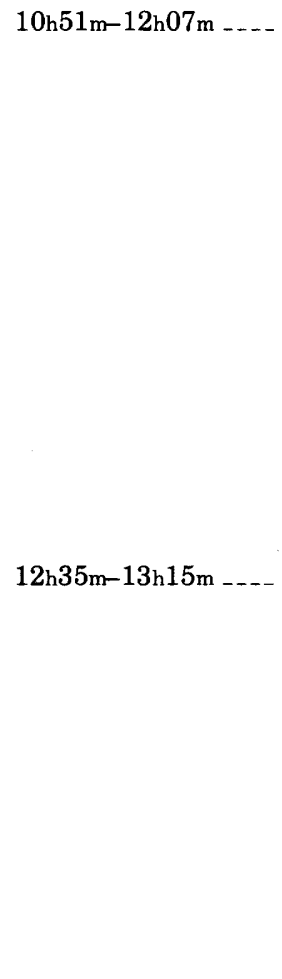 & $\begin{array}{r}1.5 \\
3.0 \\
4.5 \\
6.0 \\
7.5 \\
9.0 \\
10.5 \\
12.0 \\
13.5 \\
15.0 \\
15.5 \\
16.9 \\
18.5 \\
19.9 \\
21.5 \\
22.9 \\
24.5 \\
25.9 \\
27.5 \\
28.9 \\
1.0 \\
2.0 \\
3.0 \\
4.0 \\
5.0 \\
6.0 \\
6.5 \\
7.0 \\
7.5 \\
8.0 \\
8.5 \\
9.0 \\
9.5 \\
10.0 \\
10.5\end{array}$ & $\begin{array}{l}110 \\
140 \\
218 \\
342 \\
449 \\
555 \\
625 \\
683 \\
719 \\
752 \\
779,781 \\
781 \\
808,809 \\
811 \\
799,799 \\
785 \\
752,752 \\
722 \\
673,672 \\
633 \\
96 \\
97 \\
95 \\
97 \\
187 \\
330 \\
381 \\
425 \\
471 \\
512 \\
552 \\
583 \\
618 \\
644 \\
674\end{array}$ \\
\hline
\end{tabular}

April 13, 1964 (15.37)

$\begin{array}{lccc}* \mathrm{DH} 4--\quad 12 \mathrm{~h} 42 \mathrm{~m}-13 \mathrm{~h} 23 \mathrm{~m} \ldots- & 0.0 & 337 \\ & 1.0 & 94 \\ & 2.0 & 96 \\ 3.0 & 97 \\ & 4.0 & 125 \\ & 5.0 & 205 \\ & 6.0 & 307 \\ & 7.0 & 376\end{array}$


COOLING AND VESICULATION OF ALAE LAVA LAKE, HAWAII

TABLE 3.-Temperatures in Alae lava lake-Continued

\begin{tabular}{|c|c|c|c|}
\hline $\begin{array}{l}\text { Drill hole } \\
\text { No. }\end{array}$ & Time $^{1}$ & $\begin{array}{l}\text { Depth}{ }^{2} \\
\text { (ft) }\end{array}$ & $\underset{\left({ }^{\circ} \mathrm{C}\right)}{\text { Temperature }}$ \\
\hline * $\mathrm{DH}_{--}$ & $12 \mathrm{~h} 42 \mathrm{~m}-13 \mathrm{~h} 23 \mathrm{~m}$ & $\begin{array}{r}8.0 \\
9.0 \\
10.0 \\
10.5\end{array}$ & $\begin{array}{l}451 \\
517 \\
578 \\
605\end{array}$ \\
\hline DH5 _- & $13 \mathrm{~h} 40 \mathrm{~m}-14 \mathrm{~h} 33 \mathrm{~m}$ & $\begin{array}{r}3.0 \\
6.0 \\
9.0 \\
12.0 \\
15.0 \\
16.3 \\
19.3 \\
22.3 \\
25.3 \\
28.3\end{array}$ & $\begin{array}{l}179 \\
331 \\
492 \\
608 \\
669 \\
725 \\
744 \\
729 \\
678 \\
598\end{array}$ \\
\hline
\end{tabular}

April 16, 1964 (15.47)

\begin{tabular}{lll}
\hline DH6 $12 \mathrm{~h} 28 \mathrm{~m}-14 \mathrm{~h} 17 \mathrm{~m}-\mathrm{r}$ & 111 \\
3.0 & 153 \\
4.5 & 111 \\
6.0 & 177 \\
7.5 & 307 \\
9.0 & 428 \\
10.5 & 530 \\
12.0 & 638 \\
13.5 & 703 \\
15.0 & 808 \\
16.5 & 897 \\
18.0 & 959 \\
19.5 & $988 ; 1,004$ \\
20.5 & 1,023 \\
21.0 & 1,015 \\
22.5 & 1,$023 ; 1,032$ \\
23.5 & 1,039 \\
24.0 & 1,028 \\
25.5 & 1,$019 ; 1,027$ \\
26.5 & 1,023 \\
27.0 & 1,007 \\
28.5 & 982,989 \\
29.5 & 978 \\
30.0 & 955 \\
31.5 & 926 \\
32.5 & 905 \\
\hline
\end{tabular}

May 22, 1964 (16.59)

\begin{tabular}{|c|c|c|c|}
\hline DH6 - & $12 \mathrm{~h} 20 \mathrm{~m}-13 \mathrm{~h} 00 \mathrm{~m}$ & $\begin{array}{r}0.0 \\
1.45 \\
4.45 \\
7.45 \\
10.45 \\
13.45 \\
17.25 \\
20.25 \\
23.25 \\
26.25 \\
29.25\end{array}$ & $\begin{array}{l}339 \\
96 \\
97 \\
97 \\
554 \\
728 \\
908 \\
996 \\
1,046 \\
1,044 \\
1,005 \\
\end{array}$ \\
\hline \multicolumn{4}{|c|}{ June 9, 1964 (17.13) } \\
\hline${ }^{\circ} \mathrm{DH} 7$ & $13 \mathrm{~h} 15 \mathrm{~m}-15 \mathrm{~h} 10 \mathrm{~m}$ & $\begin{array}{c}0.0 \\
.3 \\
3.3 \\
6.3 \\
7.8 \\
9.3 \\
9.35 \\
10.8 \\
12.35 \\
13.8 \\
15.35 \\
16.8 \\
18.35 \\
21.35\end{array}$ & $\begin{array}{l}337 \\
78 \\
161 \\
274 \\
367 \\
423 \\
449 \\
523 \\
609 \\
686 \\
761 \\
828 \\
889 \\
981\end{array}$ \\
\hline
\end{tabular}

See footnotes at end of table.
TABLE 3.-Temperatures in Alae lava lake-Continued

\begin{tabular}{|c|c|c|c|}
\hline $\begin{array}{l}\text { Drill hole } \\
\text { No. }\end{array}$ & Time $^{1}$ & $\begin{array}{c}\text { Depth }^{2} \\
\text { (ft) }\end{array}$ & $\begin{array}{c}\text { Temperature } \\
\left({ }^{\circ} \mathrm{C}\right)\end{array}$ \\
\hline \multicolumn{4}{|c|}{ June 17, 1964 (17.36) } \\
\hline DH5 .. & $13 \mathrm{~h} 45 \mathrm{~m}-14 \mathrm{~h} 18 \mathrm{~m}$ & $\begin{array}{r}0.0 \\
3.0 \\
6.0 \\
9.0 \\
12.0 \\
16.4 \\
19.4 \\
22.4 \\
25.4\end{array}$ & $\begin{array}{c}352 \\
236 \\
356 \\
456 \\
513 \\
578 \\
579 \\
557 \\
510\end{array}$ \\
\hline
\end{tabular}

July 2, 1964 (17.79)

\begin{tabular}{rrr}
$* \mathrm{DH} 8$ - $\quad 11 \mathrm{~h} 00 \mathrm{~m}-12 \mathrm{~h} 55 \mathrm{~m}---$ & 1.5 & 96 \\
& 3.0 & 99 \\
4.5 & 110 \\
6.0 & 231 \\
7.5 & 322 \\
9.0 & 407 \\
10.5 & 483 \\
12.0 & 556 \\
13.5 & 621 \\
15.0 & 690,706 \\
16.3 & 765 \\
18.0 & 843 \\
19.3 & 894 \\
21.0 & 956 \\
22.3 & 996 \\
24.0 & 1,032 \\
25.3 & 1,047 \\
27.0 & 1,049 \\
28.3 & 1,044 \\
\hline
\end{tabular}

July 27, 1964 (18.48)

$\begin{array}{rrr}* \mathrm{DH} 8_{--} \quad 15 \mathrm{~h} 16 \mathrm{~m}-15 \mathrm{~h} 55 \mathrm{~m}---- & 0.0 & 343 \\ & 3.0 & 102 \\ 6.0 & 256 \\ 9.0 & 431,436 \\ 12.0 & 573,580 \\ 15.0 & 698,710 \\ 18.0 & 827 \\ 21.0 & 920 \\ & \end{array}$

September 3, 1964 (19.49)

\begin{tabular}{rrr}
\hline DH8 $--\quad 13 \mathrm{~h} 20 \mathrm{~m}-15 \mathrm{~h} 30 \mathrm{~m}-\ldots-$ & 0.0 & 53 \\
& 1.5 & 92 \\
& 3.0 & 112 \\
4.5 & 174 \\
6.0 & 272 \\
7.5 & 377 \\
10.5 & 513 \\
13.5 & 632 \\
16.5 & 742 \\
19.5 & 834
\end{tabular}

December 8, 1964 (21.81)

\begin{tabular}{rrc}
\hline $\mathrm{DH} 12 \quad 10 \mathrm{~h} 05 \mathrm{~m}-10 \mathrm{~h} 57 \mathrm{~m}-\ldots-$ & 0.0 & 336 \\
& 3.0 & 273 \\
6.0 & 414 \\
9.0 & 544 \\
12.0 & 639 \\
15.0 & 716 \\
18.0 & 774 \\
21.0 & 828 \\
24.0 & 863 \\
27.0 & 871 \\
\hline
\end{tabular}


TABLE 3.-Temperatures in Alae lava lake-Continued

\begin{tabular}{lccc}
\hline $\begin{array}{c}\text { Drill hole } \\
\text { No. }\end{array}$ & Time $^{1}$ & $\begin{array}{c}\text { Depth } \\
(\mathrm{ft})\end{array}$ & $\begin{array}{c}\text { Temperature } \\
\left({ }^{\circ} \mathrm{C}\right)\end{array}$ \\
\hline
\end{tabular}

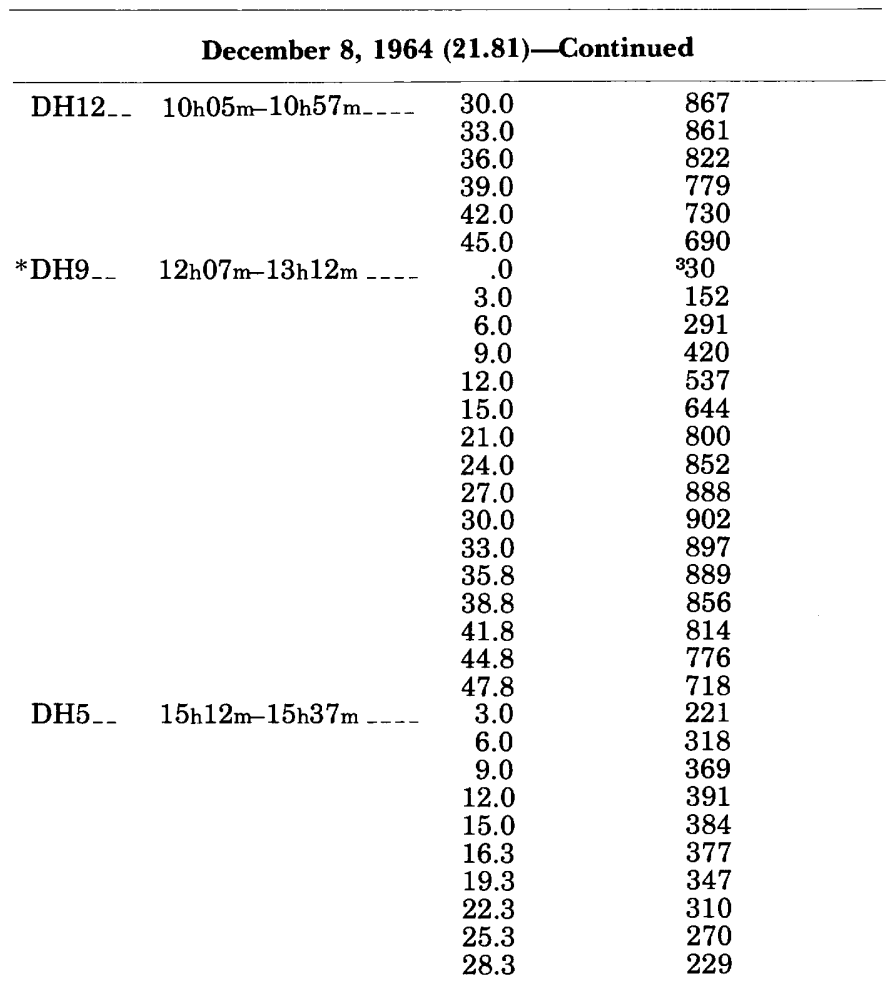

January 21, 1965 (22.79)

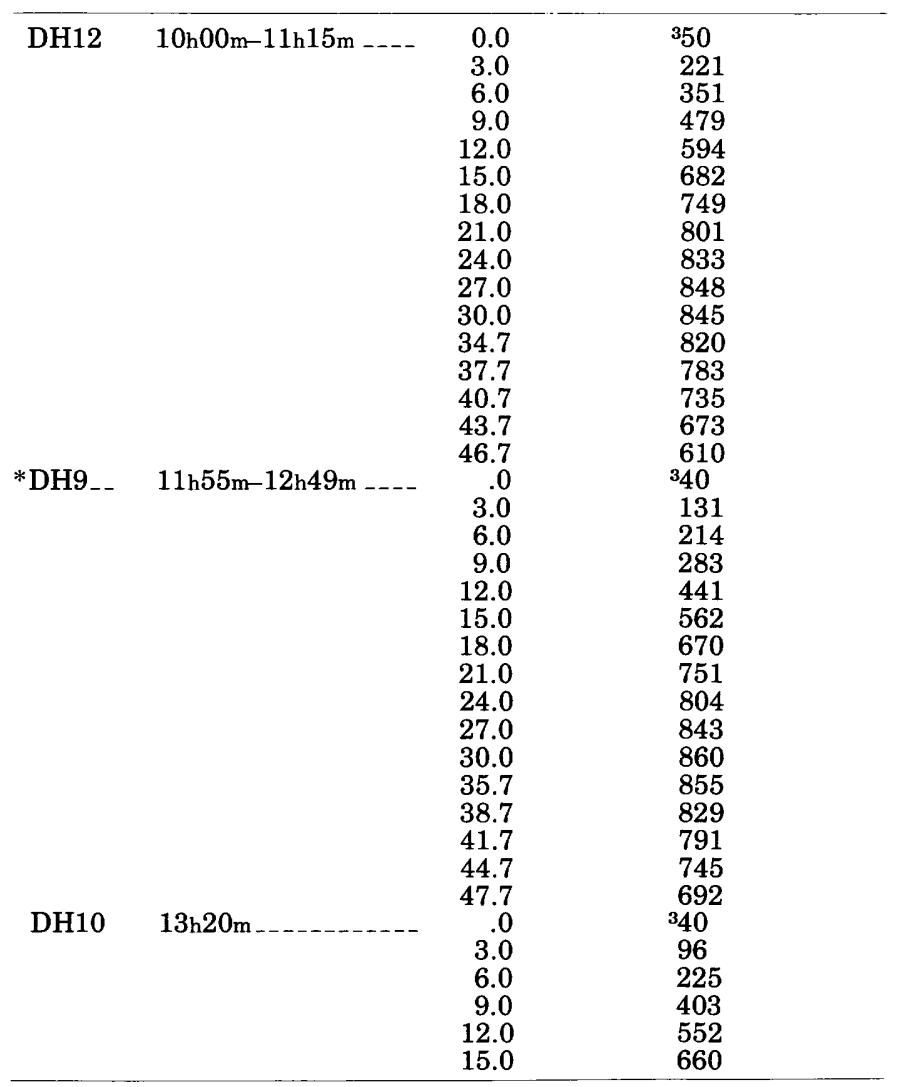

See footnotes at end of table.
TABLE 3.-Temperatures in Alae lava lake-Continued

\begin{tabular}{|c|c|c|c|}
\hline $\begin{array}{l}\text { Drill hole } \\
\text { No. }\end{array}$ & Time $^{1}$ & $\begin{array}{l}\operatorname{Depth}^{2} \\
\text { (ft) }\end{array}$ & $\begin{array}{l}\text { Temperature } \\
\left({ }^{\circ} \mathrm{C}\right)\end{array}$ \\
\hline DH11 & $13 \mathrm{~h} 52 \mathrm{~m}$ & $\begin{array}{r}.0 \\
3.0 \\
6.0 \\
9.0 \\
12.0 \\
15.0\end{array}$ & $\begin{array}{c}342 \\
145 \\
250 \\
355 \\
473 \\
579\end{array}$ \\
\hline DH5 & $15 \mathrm{~h} 15 \mathrm{~m}-15 \mathrm{~h} 40 \mathrm{~m}$ & $\begin{array}{r}.0 \\
3.0 \\
6.0 \\
9.0 \\
12.0 \\
15.0 \\
16.3 \\
19.3 \\
22.3 \\
25.3 \\
28.3\end{array}$ & $\begin{array}{c}330 \\
159 \\
231 \\
289 \\
322 \\
326 \\
321 \\
297 \\
264 \\
229 \\
192\end{array}$ \\
\hline
\end{tabular}

March 2, 1965 (23.65)

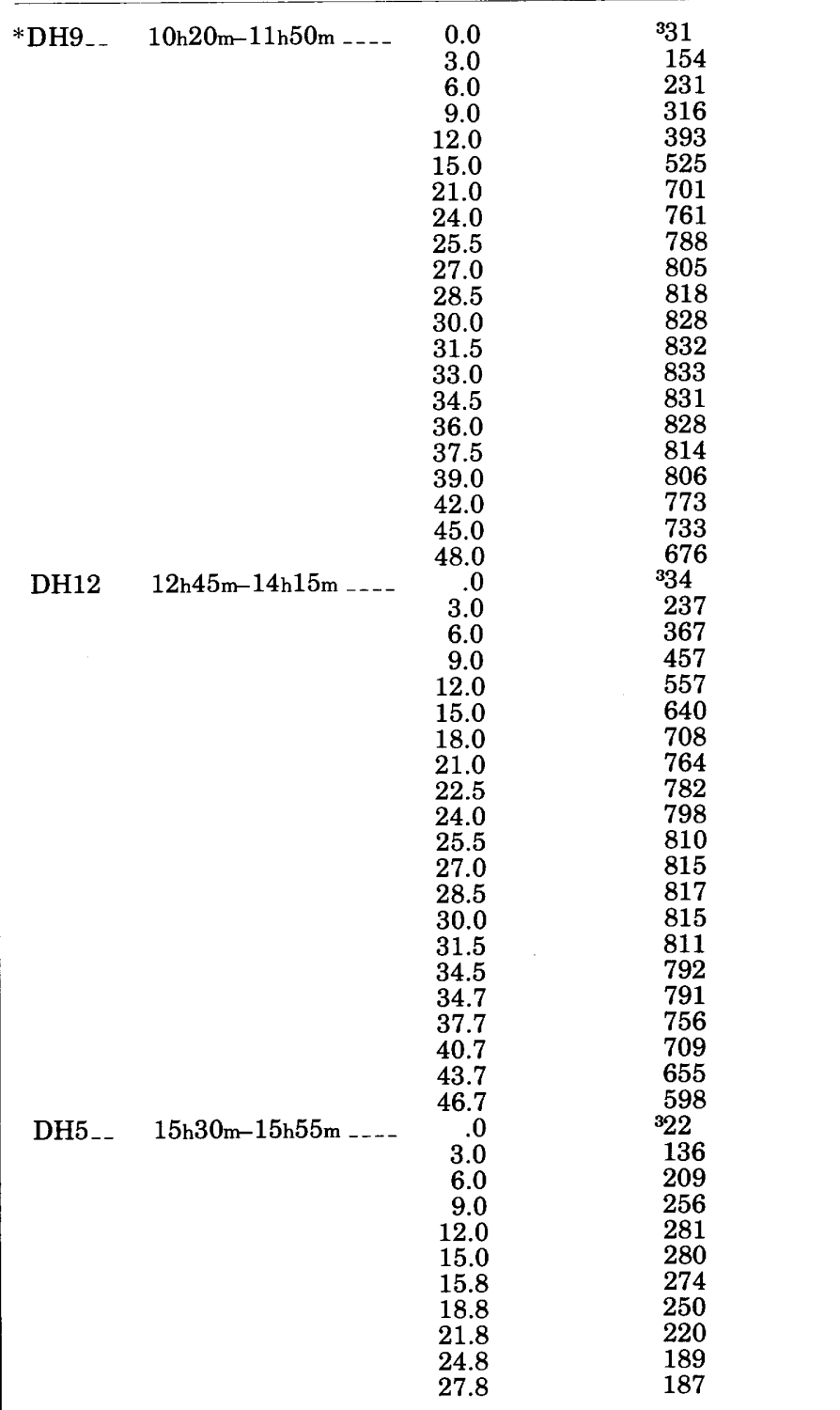


COOLING AND VESICULATION OF ALAE LAVA LAKE, HAWAII

TABLE 3.-Temperatures in Alae lava lake-Continued

\begin{tabular}{|c|c|c|c|}
\hline $\begin{array}{l}\text { Drill hole } \\
\text { No. }\end{array}$ & Time $^{1}$ & $\underset{(\mathrm{ft})}{\operatorname{Depth}^{2}}$ & $\underset{\left({ }^{\circ} \mathrm{C}\right)}{\text { Temperature }}$ \\
\hline \multicolumn{4}{|c|}{ August 19, 1965 (27.01) } \\
\hline * DH9 & $10 \mathrm{~h} 05 \mathrm{~m}-12 \mathrm{~h} 20 \mathrm{~m}$ & $\begin{array}{r}6.0 \\
9.0 \\
12.0 \\
15.0 \\
18.0 \\
21.0 \\
24.0 \\
27.0 \\
30.0 \\
31.5 \\
33.0 \\
34.5 \\
35.9 \\
37.5 \\
38.9 \\
40.5 \\
41.9 \\
43.5 \\
44.9 \\
47.9\end{array}$ & $\begin{array}{l}125 \\
181 \\
249 \\
339 \\
406 \\
474 \\
538 \\
596 \\
637 \\
658 \\
664 \\
679 \\
684 \\
687 \\
686 \\
682 \\
675 \\
666 \\
653 \\
616\end{array}$ \\
\hline 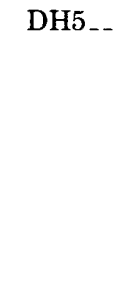 & $12 \mathrm{~h} 40 \mathrm{~m}-13 \mathrm{~h} 50 \mathrm{~m}$ & $\begin{array}{r}3.0 \\
6.0 \\
9.0 \\
12.0 \\
15.0 \\
15.8 \\
18.8 \\
21.8 \\
24.8 \\
27.8\end{array}$ & $\begin{array}{l}51 \\
56 \\
74 \\
88 \\
94 \\
94 \\
93 \\
85 \\
75 \\
66\end{array}$ \\
\hline$* \mathrm{DH} 12$ & $14 \mathrm{~h} 40 \mathrm{~m}-16 \mathrm{~h} 12 \mathrm{~m}$ & $\begin{array}{r}3.0 \\
6.0 \\
9.0 \\
12.0 \\
15.0 \\
20.0 \\
23.0 \\
24.5 \\
26.0 \\
27.5 \\
29.0 \\
30.5 \\
32.0 \\
33.5 \\
35.0 \\
36.5 \\
38.0 \\
41.0 \\
44.0 \\
47.0\end{array}$ & $\begin{array}{l}185 \\
253 \\
319 \\
390 \\
456 \\
559 \\
606 \\
629 \\
642 \\
656 \\
663 \\
670 \\
669 \\
671 \\
669 \\
658 \\
654 \\
626 \\
585 \\
543\end{array}$ \\
\hline \multicolumn{4}{|c|}{ May 27, 1966 (31.78) } \\
\hline *DH12 & $11 \mathrm{~h} 00 \mathrm{~m}-14 \mathrm{~h} 05 \mathrm{~m}$ & $\begin{array}{r}2.8 \\
5.8 \\
8.8 \\
11.8\end{array}$ & $\begin{array}{l}193 \\
237 \\
273 \\
295\end{array}$ \\
\hline
\end{tabular}

TABLE 3.-Temperatures in Alae lava lake-Continued

\begin{tabular}{|c|c|c|c|}
\hline $\begin{array}{l}\text { Drill hole } \\
\text { No. }\end{array}$ & Time $^{1}$ & $\begin{array}{c}\text { Depth}^{2} \\
(\mathrm{ft})\end{array}$ & $\begin{array}{l}\text { Temperature } \\
\left({ }^{\circ} \mathrm{C}\right)\end{array}$ \\
\hline *DH12 & $11 \mathrm{~h} 00 \mathrm{~m}-14 \mathrm{~h} 05 \mathrm{~m} \ldots$ & $\begin{array}{l}14.8 \\
17.8 \\
20.8 \\
23.8 \\
26.8 \\
29.8 \\
32.8 \\
33.8 \\
34.8 \\
35.8 \\
36.8 \\
37.8 \\
38.8 \\
39.8 \\
40.8 \\
41.8 \\
42.8 \\
43.8 \\
44.8 \\
45.8 \\
46.8\end{array}$ & $\begin{array}{l}315 \\
338 \\
355 \\
377 \\
402 \\
431 \\
456 \\
462 \\
467 \\
471 \\
473 \\
475 \\
477 \\
475 \\
474 \\
472 \\
468 \\
464 \\
456 \\
451 \\
448\end{array}$ \\
\hline *DH9 -- & $14 \mathrm{~h} 20 \mathrm{~m}-15 \mathrm{~h} 30 \mathrm{~m}$ & $\begin{array}{r}.6 \\
3.6 \\
6.6 \\
9.6 \\
11.1 \\
12.6 \\
15.6 \\
18.6 \\
21.6 \\
24.6 \\
\text { (Block }\end{array}$ & $\begin{array}{l}62 \\
30 \\
40 \\
66 \\
68 \\
110 \\
121 \\
116 \\
164 \\
165 \\
\text { mates at } 24.6 \mathrm{ft} \text { ) }\end{array}$ \\
\hline
\end{tabular}

August 31, 1967 (38.35)

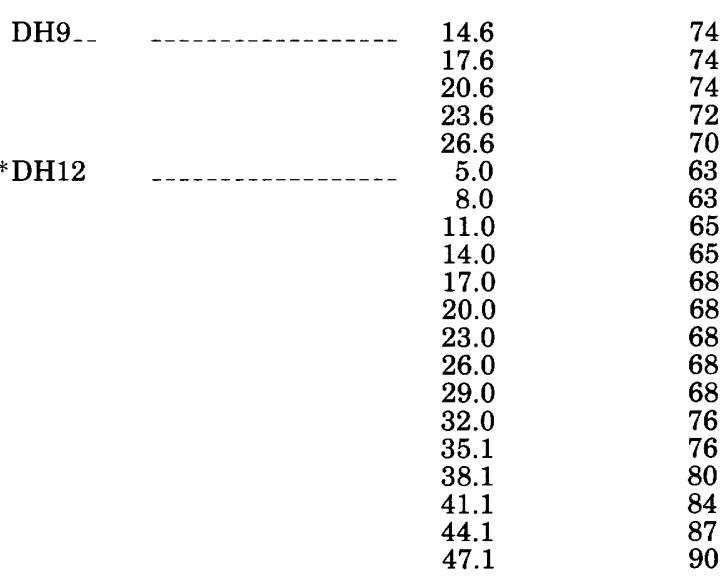

${ }^{1}$ All times are given in hours and minutes, Hawaii Standard Time.

${ }^{2} 1$ foot equals $0.3048 \mathrm{~m}$.

${ }^{3}$ Measured with a mercury thermometer.

${ }^{4}$ Measured with a thermocouple of platinum-platinum plus 10 percent rhodium. 
